\title{
IEA Wind TCP Task 26: Offshore Wind Energy International Comparative Analysis
}

Noonan, Miriam ; Stehly, Tyler; Mora Alvarez, David Fernando; Kitzing, Lena; Smart, Gavin; Berkhout, Volker; Kikuch, Yuka

Publication date:

2018

Document Version

Publisher's PDF, also known as Version of record

Link back to DTU Orbit

Citation (APA):

Noonan, M., Stehly, T., Mora Alvarez, D. F., Kitzing, L., Smart, G., Berkhout, V., \& Kikuch, Y. (2018). IEA Wind TCP Task 26: Offshore Wind Energy International Comparative Analysis.

\section{General rights}

Copyright and moral rights for the publications made accessible in the public portal are retained by the authors and/or other copyright owners and it is a condition of accessing publications that users recognise and abide by the legal requirements associated with these rights.

- Users may download and print one copy of any publication from the public portal for the purpose of private study or research.

- You may not further distribute the material or use it for any profit-making activity or commercial gain

- You may freely distribute the URL identifying the publication in the public portal

If you believe that this document breaches copyright please contact us providing details, and we will remove access to the work immediately and investigate your claim 


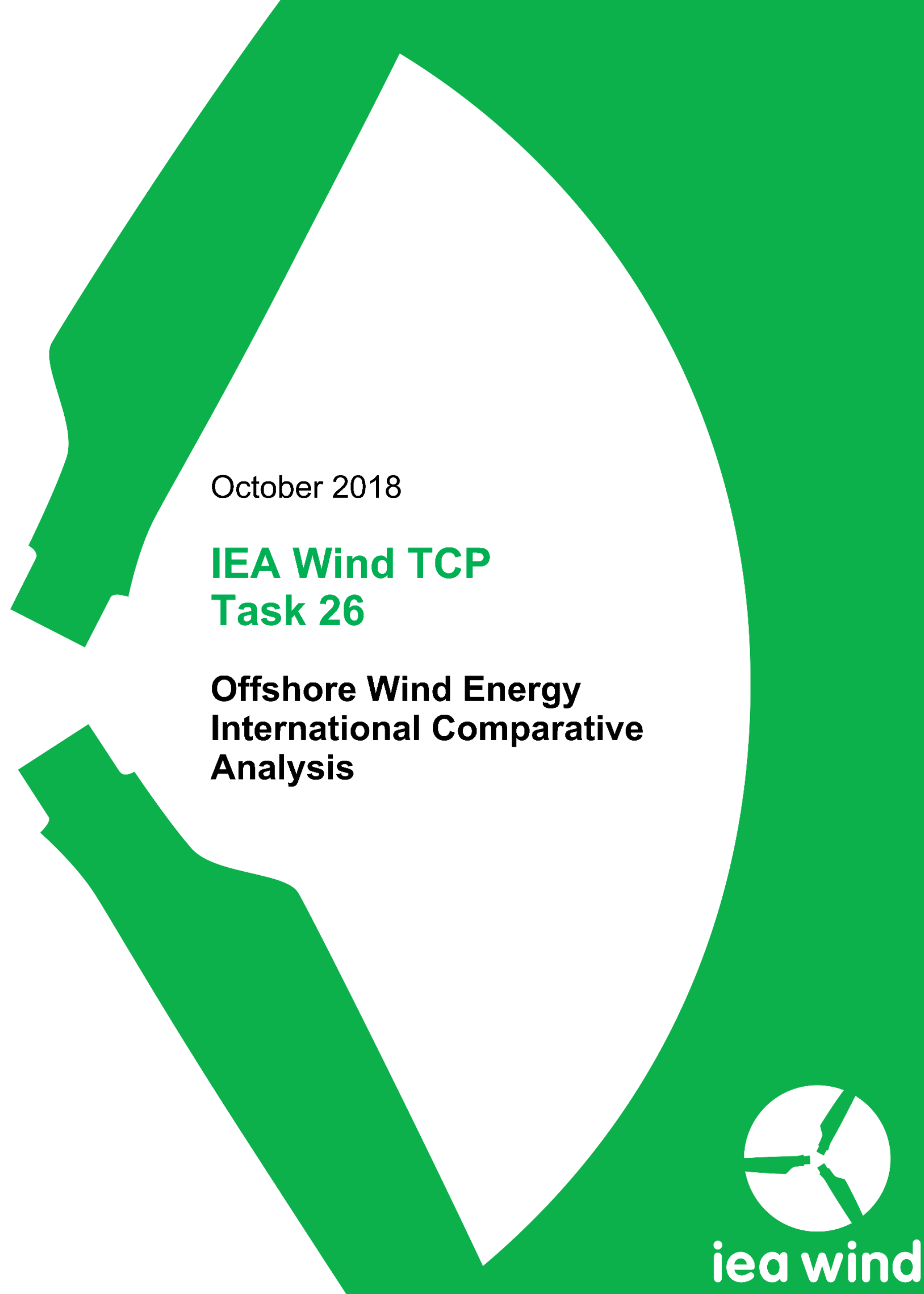




\section{GNREL}

\section{IEA Wind TCP Task 26: Offshore Wind Energy International Comparative Analysis}

Miriam Noonan, ${ }^{1}$ Tyler Stehly, ${ }^{2}$ David Mora,${ }^{3}$ Lena Kitzing, ${ }^{3}$ Gavin Smart, ${ }^{1}$ Volker Berkhout, ${ }^{4}$ and Yuka Kikuchi ${ }^{5}$

1 Offshore Renewable Energy Catapult

${ }^{2}$ National Renewable Energy Laboratory

${ }^{3}$ Technical University of Denmark

${ }^{4}$ Fraunhofer Institute

${ }^{5}$ University of Tokyo

NREL is a national laboratory of the U.S. Department of Energy Office of Energy Efficiency \& Renewable Energy Operated by the Alliance for Sustainable Energy, LLC

This report is available at no cost from the National Renewable Energy Laboratory (NREL) at www.nrel.gov/publications.

Contract No. DE-AC36-08GO28308
Technical Report NREL/TP-6A20-71558 October 2018

National Renewable Energy Laboratory 15013 Denver West Parkway Golden, CO 80401

303-275-3000 • www.nrel.gov 


\section{NOTICE}

This work was authored in part by the National Renewable Energy Laboratory, operated by Alliance for Sustainable Energy, LLC, for the U.S. Department of Energy (DOE) under Contract No. DE-AC36-08G028308. Funding provided by the U.S. Department of Energy Office of Energy Efficiency and Renewable Energy, Wind and Water Technologies Office. The views expressed herein do not necessarily represent the views of the DOE or the U.S. Government. The U.S. Government retains and the publisher, by accepting the article for publication, acknowledges that the U.S. Government retains a nonexclusive, paid-up, irrevocable, worldwide license to publish or reproduce the published form of this work, or allow others to do so, for U.S. Government purposes.

This report is available at no cost from the National Renewable Energy Laboratory (NREL) at www.nrel.gov/publications.

U.S. Department of Energy (DOE) reports produced after 1991 and a growing number of pre-1991 documents are available free via www.OSTI.gov.

Cover Photos by Dennis Schroeder: (clockwise, left to right) NREL 51934, NREL 45897, NREL 42160, NREL 45891, NREL 48097, NREL 46526 .

NREL prints on paper that contains recycled content. 
Prepared for the

International Energy Agency Wind Implementing Agreement

October 2018

\section{Authors}

\begin{tabular}{|lll|}
\hline Miriam Noonan & Offshore Renewable Energy Catapult & United Kingdom \\
\hline Tyler Stehly & National Renewable Energy Laboratory & United States \\
\hline $\begin{array}{l}\text { David Mora and } \\
\text { Lena Kitzing }\end{array}$ & Technical University of Denmark & Denmark \\
\hline Gavin Smart & Offshore Renewable Energy Catapult & United Kingdom \\
\hline Volker Berkhout & Fraunhofer Institute & Germany \\
\hline Yuka Kikuchi & University of Tokyo & Japan \\
\hline
\end{tabular}

\section{Disclaimer:}

IEA Wind TCP functions within a framework created by the International Energy Agency (IEA). Views, findings, and publications of IEA Wind do not necessarily represent the views or policies of the IEA Secretariat or of all its individual member countries. IEA Wind is part of IEA's Technology Collaboration Programme (TCP).

\section{Suggested Citation:}

Noonan, M., T. Stehly, D. Mora, L. Kitzing, G. Smart, V. Berkhout, Y. Kikuchi. IEA Wind TCP Task 26-Offshore Wind International Comparative Analysis, International Energy Agency Wind Technology Collaboration Programme. 


\section{Acknowledgements}

Special thanks to Maureen Hand (National Renewable Energy Laboratory), Andreas Uihlein, and Roberto Lacal Arántegui (both European Commission Joint Research Centre) for detailed comments and input on earlier versions of this report.

This report has been sponsored by the International Energy Agency (IEA) Wind Implementing Agreement (part of the Technology Collaboration Programme) for Co-operation in the Research, Development, and Deployment of Wind Energy Systems (IEA Wind), and funded by the respective entities in the participating countries of Task 26-The Cost of Wind Energy, including Denmark, Germany, Ireland, the Netherlands, the European Commission, and the United States. The authors of this report would like to thank the IEA Wind Executive Committee members for supporting this work, particularly those members who sponsor the corresponding research in each of the participating countries.

IEA was founded in 1974 within the framework of the Organisation for Economic Co-operation and Development to collaborate on international energy programs and carry out a comprehensive program about energy among member countries. 


\section{List of Acronyms}

$\begin{array}{ll}\text { AEP } & \text { annual energy production } \\ \text { BNetzA } & \text { Bundesnetzagentur (German federal grid agency) } \\ \text { BOEM } & \begin{array}{l}\text { Bureau of Ocean Energy Management } \\ \text { contract for difference } \\ \text { CfD }\end{array} \\ \text { CRMF } & \text { Dost Reduction Monitoring Framework } \\ \text { DTU } & \text { final investment decision } \\ \text { FID } & \text { final investment decision enabling for renewables } \\ \text { FIDER } & \text { U.S. Internal Revenue Service } \\ \text { IRS } & \text { levelised cost of energy } \\ \text { LCOE } & \text { mean wind speed } \\ \text { MWS } & \text { Norwegian Ministry of Oil and Energy } \\ \text { OED } & \text { offshore transmission operator } \\ \text { OFTO } & \text { Renewable Obligation Certificate } \\ \text { ROC } & \text { strategic impact assessment } \\ \text { SIA } & \text { weighted average cost of capital } \\ \text { WACC } & \text { wind energy area } \\ \text { WEA } & \end{array}$




\section{Executive Summary}

This report for International Energy Agency Task 26 examines the physical site characteristics, technology choices, and regulatory context driving levelized cost of energy (LCOE) in key countries for offshore wind farms being commissioned in 2017 and 2018. These inputs have been agreed with Task 26 participants and modelling has been conducted by Offshore Renewable Energy Catapult.

It is crucial to note that the analysis included in this report is intended to reflect the LCOE for offshore wind projects being commissioned in 2017 and 2018. Technology is changing quickly in the offshore wind industry and projects taking final investment decision in 2017 (to be commissioned in 2020 onward) vary drastically from sites being commissioned in 2017. Much of the publicity surrounding offshore wind relates to auction results or cost estimates for wind farms to be commissioned in the $2020 \mathrm{~s}$. This cost reduction can be attributed to progress in several main areas of innovation, including 10-MW + turbines, advanced O\&M strategies and market maturity leading to longer life assets with higher power output and a perceived lower risk investment.

Although individual project conditions are expected to drive significant variability in costs within a given country, representative country-specific assumptions have been applied one by one to capture the individual impact on LCOE of site characteristics (e.g., wind speed, water depth, and distance from shore), technology choice (e.g., turbine rating, foundation type, and array cable type) and regulatory environment (e.g., cost of capital, tax, socialised development and/or transmission costs, and other regulatory charges).

Starting from a central baseline reference case ${ }^{1}$ with an LCOE of $€ 130 /$ megawatt-hour, the relative change in LCOE is shown in Figure ES1 at each step. The range of LCOE varies significantly when all country-specific aspects are considered, and this analysis provides a number of insights:

- For the countries considered, financial and regulatory environment have a greater impact than physical site characteristics.

- The majority of sites are using turbine ratings higher than the 4-megawatt (MW) baseline site (with the exception of the Netherlands), showing the fast uptake of new technology in this area. Turbine rating has a large secondary impact on foundation, cable, and operation and maintenance costs.

- Across the global sites chosen, average water depth is broadly similar. Japan and Denmark stand out as having particularly shallow sites, although in the long term, Japan expects up to $80 \%$ of development to be in sites of water depths over 50 metres.

- Within the scope of this study, distance to cable landfall has a bigger impact on LCOE than distance to port because of the additional cost of export cables. For some sites with frequent adverse weather conditions, there may be a higher impact on reliability however this wasn't deemed applicable for the sites modelled in this report.

\footnotetext{
${ }^{1}$ The baseline case uses the offshore wind generic baseline site documented in the 2015 report, which estimated LCOE as $€ 146 /$ megawatt-hour (Real 2014). Figure ES1 has been revised to reflect an up-to-date estimate of LCOE for the same site being commissioned in 2016/2017 based on movements in costs since 2015 .
} 
- Mean wind speed has a significant impact on power output and hence LCOE. Japan, in particular, sees an increase in LCOE as a result of a lower average wind speed (8.7 metres per second at hub height) compared to the baseline site ( 9.9 metres per second at hub height).

- Japan, with a representative site capacity of $73 \mathrm{MW}$ for an initial phase development, stands out for its jump in cost on a "per megawatt" basis when the low wind farm capacity is incorporated. This cost increase is offset by the reduced distance to shore, for which installing four lower-capacity export cables direct to shore makes more financial sense.

- Depending on site conditions alone, the Japan site has the highest LCOE. Although an attractive debt interest rate reduces the weighted average cost of capital to $6 \%$ giving a lower LCOE, it remains the highest LCOE site. The LCOE for the U.S. site increases because of a much higher debt interest rate than other countries, which coincides with a choice to use a lower debt ratio. For projects that would have been commissioned in 2017 and 2018, the United States also has a higher corporate tax rate than the other countries within the study.

- The LCOE spread widens particularly at the point that local legislation is accounted for, where socialised development and transmission capex in Denmark, Germany, and the Netherlands removes $21 \%-24 \%$ of capital expenditures from developers' scope. The combination of the second lowest weighted average cost of capital $(6.0 \%)$, reduced development costs, and socialised transmission reduces Germany's LCOE to the second lowest after the local financial regime is considered.

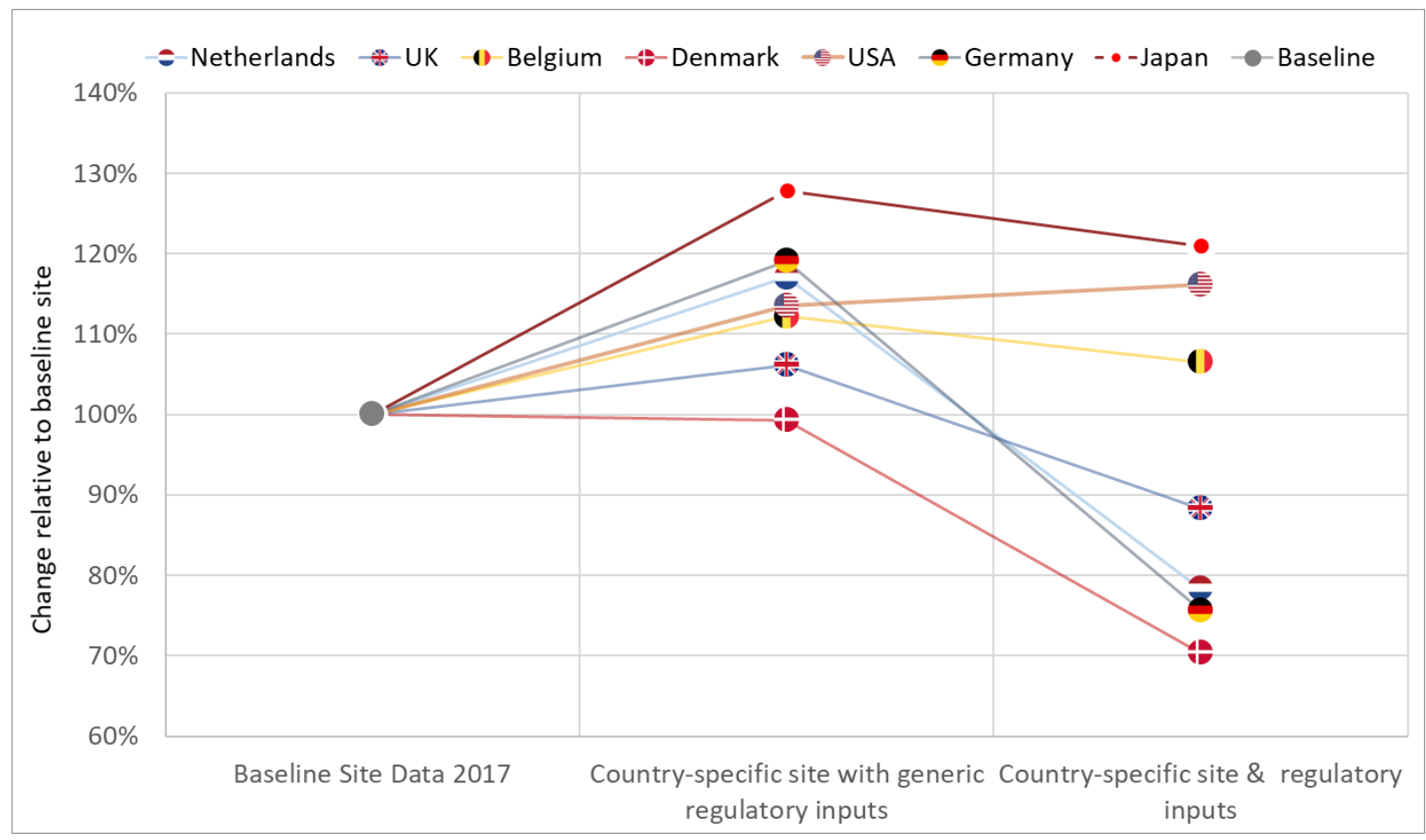

Figure ES1. LCOE impact of changing country-specific parameters

In the longer term, there is an expectation that developers will seek higher wind speeds found in sites with more difficult conditions - deeper water, farther distance from shore, and so on - and floating wind turbines may be commercially ready to meet these challenges in the next 10 years. 


\section{Table of Contents}

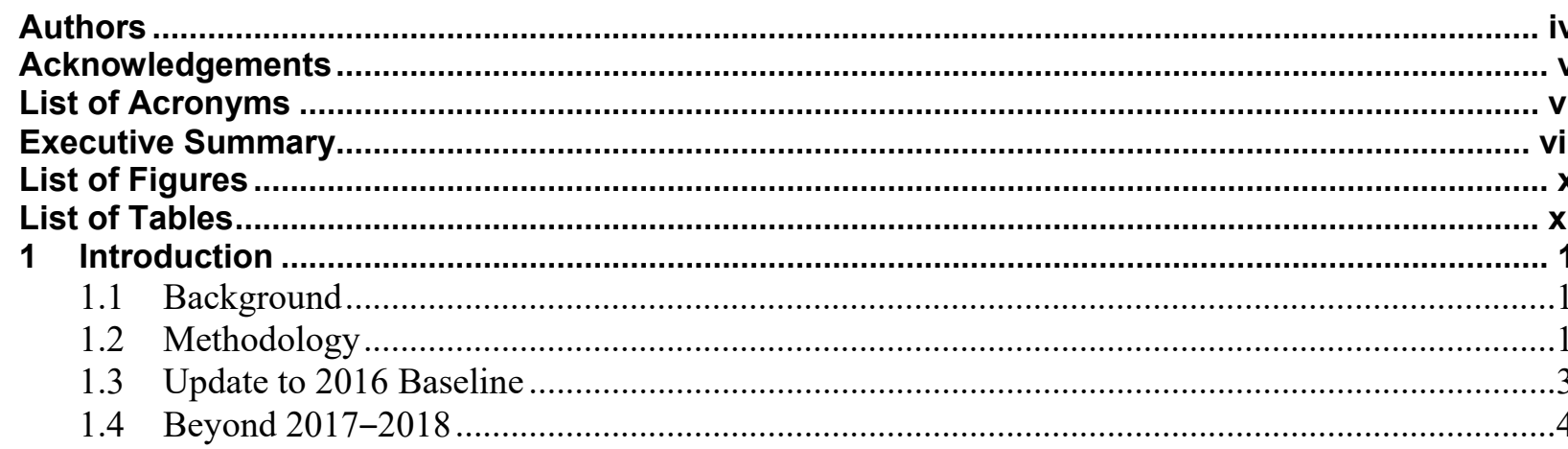

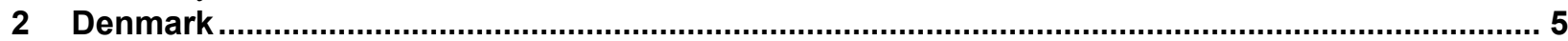

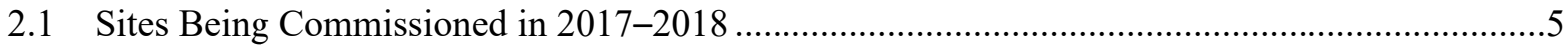

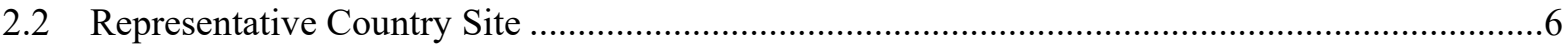

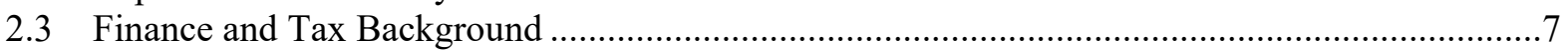

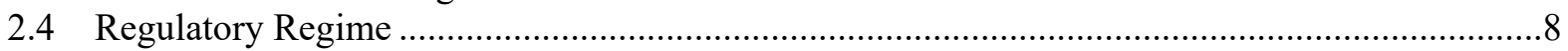

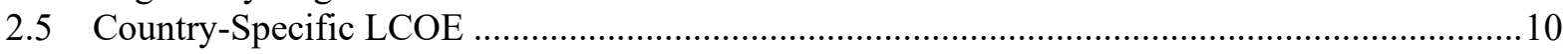

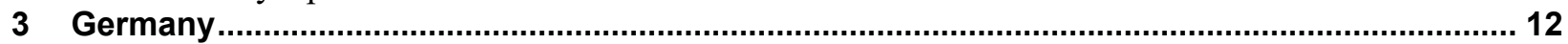

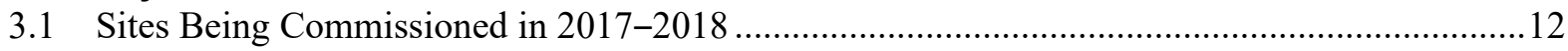

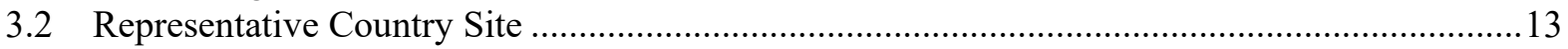

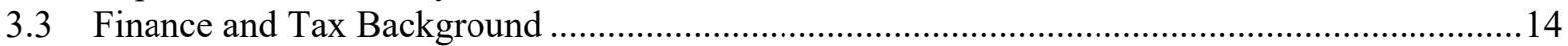

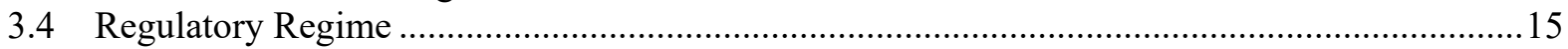

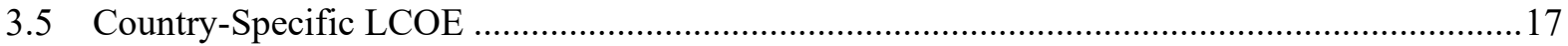

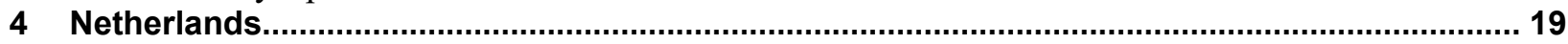

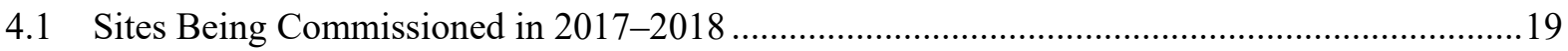

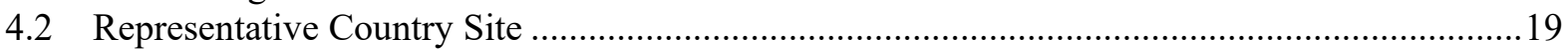

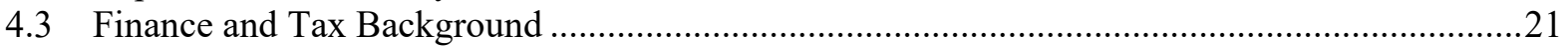

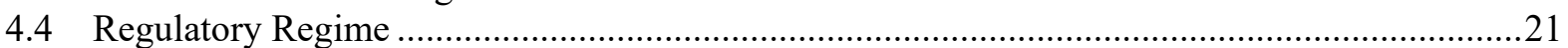

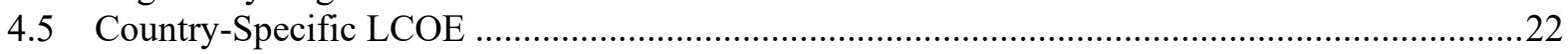

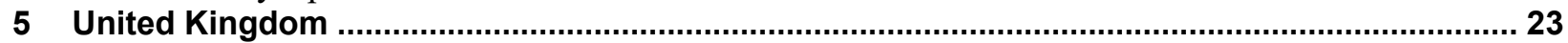

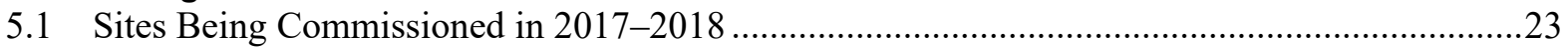

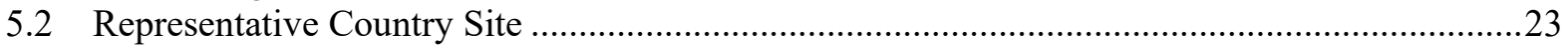

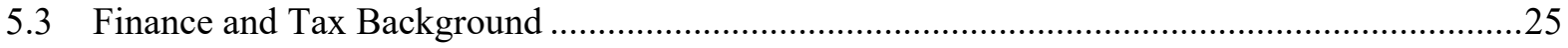

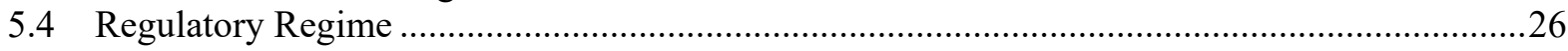

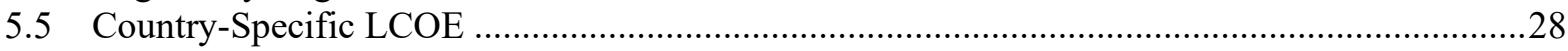

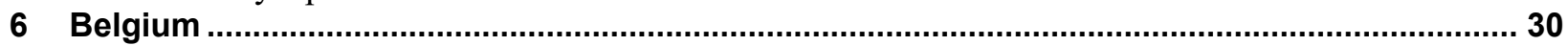

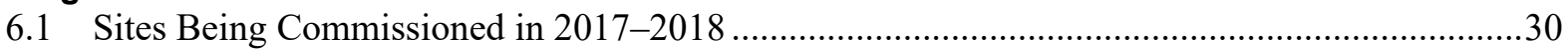

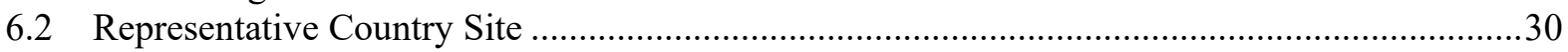

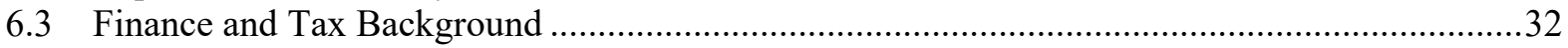

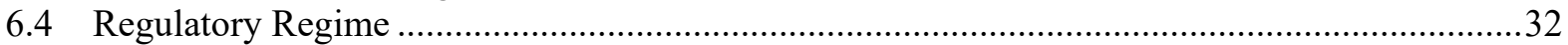

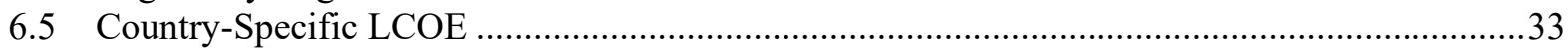

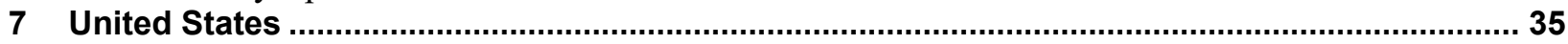

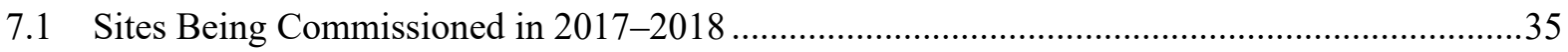

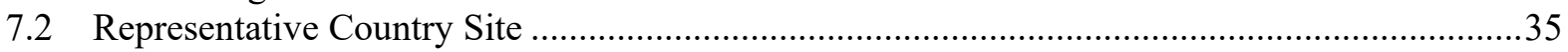

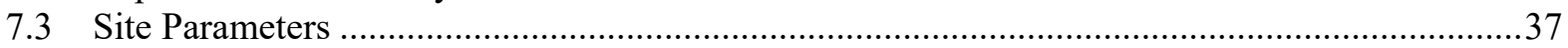

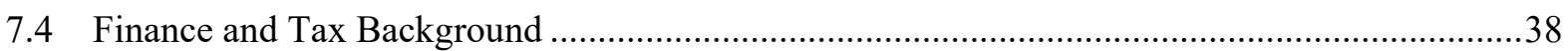

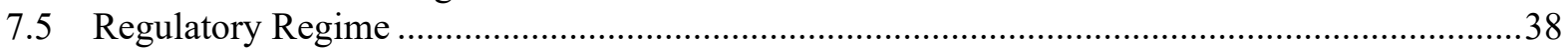

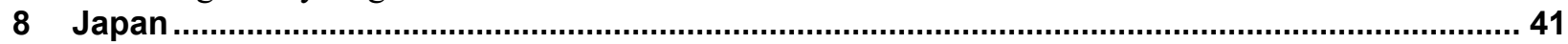

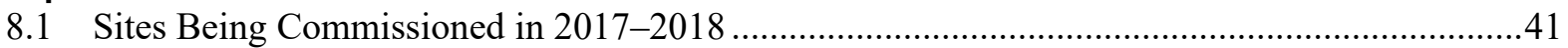

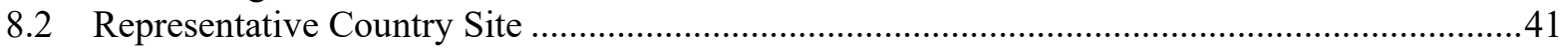

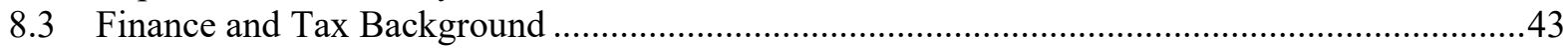

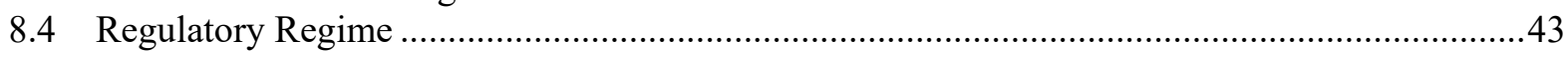




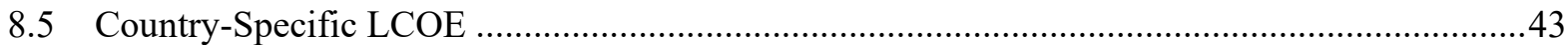

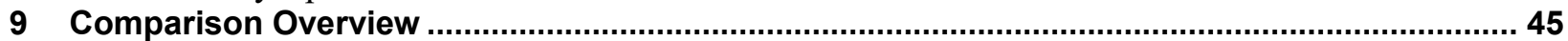

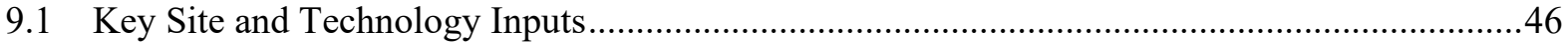

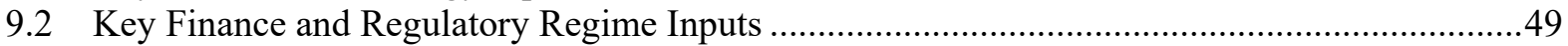

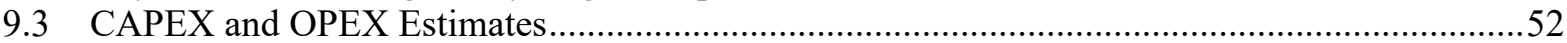

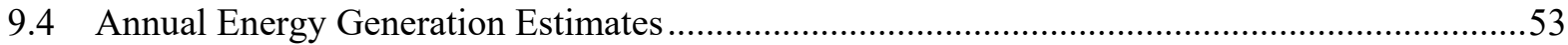

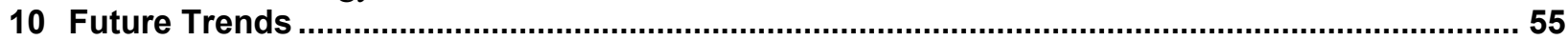

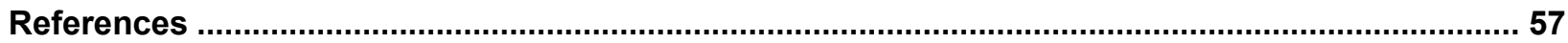

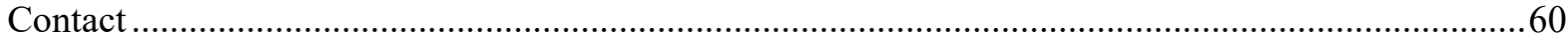

\section{List of Figures}

Figure ES1. LCOE impact of changing country-specific parameters ............................................ viii

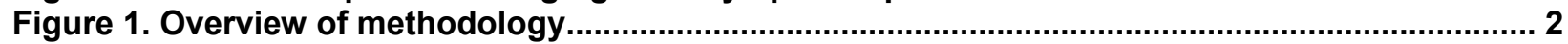

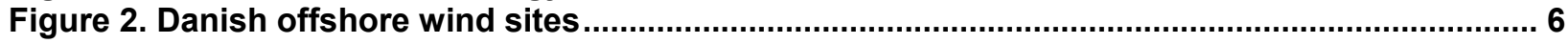

Figure 3. Waterfall chart of Danish representative site ................................................................. 11

Figure 4. German offshore wind sites (Source: German Maritime and Hydrography Agency [BSH]) Figure 5. (Left) Wind speed distribution (2004-2012) at the meteorological mast FINO1 at the 90-m 90-m height (Sources: Fraunhofer IEE Wind Energy Report 2016 and BSH) ........................... 14

Figure 6. Time period of initial payment for offshore wind turbines in Germany (Renewable Energy

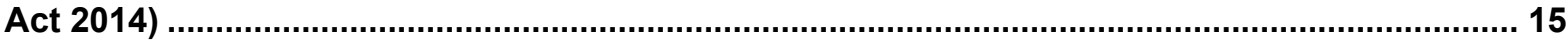

Figure 7. Feed-in payments for offshore electricity (Fraunhofer IEE Wind Energy Report 2017).... 16

Figure 8. Waterfall chart of German representative site............................................................. 18

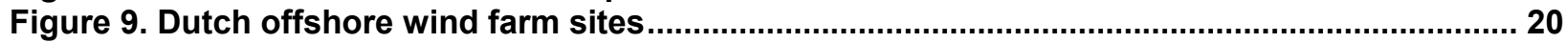

Figure 10. Waterfall chart of Dutch representative site ............................................................. 22

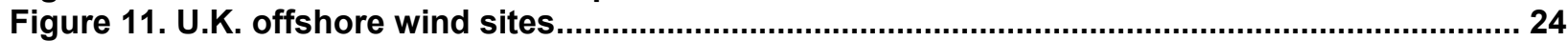

Figure 12. Waterfall chart of U.K. representative site .................................................................. 29

Figure 13. Belgian offshore wind sites. Image from the Renewable Energy Base Oostende .......... 31

Figure 14. Waterfall chart of Belgian representative site .............................................................. 34

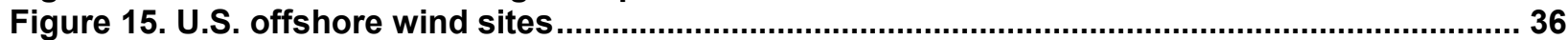

Figure 16. Waterfall chart of U.S. representative site ............................................................... 40

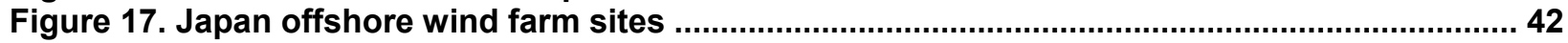

Figure 18. Waterfall chart of Japan representative site.................................................................. 44

Figure 19. LCOE impact of changing country-specific parameters ............................................ 45

Figure 20. Water depth against LCOE for modelled sites and impact of changing baseline water depth

Figure 21. Distance to port against LCOE for modelled sites and impact of changing baseline

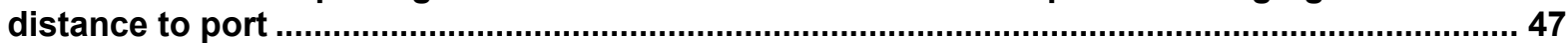

Figure 22. Distance to cable landfall against LCOE for modelled sites and impact of changing baseline distance-to-cable landfall

Figure 23. Turbine rating against $L C O E$ for modelled sites

Figure 24. Impact of country-specific financial framework on LCOE .......................................... 50 51

Figure 25. Debt interest rate against LCOE for modelled sites and impact of changing baseline

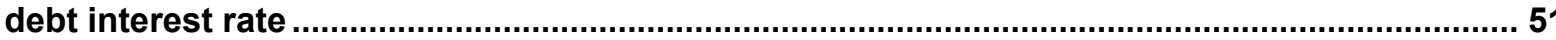

Figure 27. Debt ratio against LCOE for modelled sites and impact of changing baseline debt ratio

Figure 26. Equity return against LCOE for modelled sites and impact of changing baseline equity

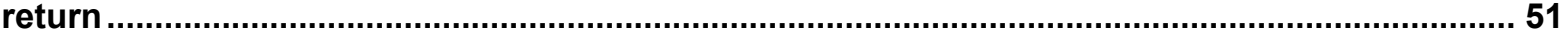

Figure 28. Tax rate against LCOE for modelled sites and impact of changing baseline tax rate .... 52 


\section{List of Tables}

Table 1. Update on Baseline Capital Expenditure(CAPEX) Figures from 2016 to 2017 3

Table 2. Update on Baseline Operational Expenditure (OPEX) Figures from 2016 to 2017.............. 4

Table 3. Danish Site Parameters …........................................................................................... 5

Table 4. Results of Danish Offshore Wind Farm Tender Rounds …........................................... 9

Table 5. German Site Parameters ........................................................................................ 12

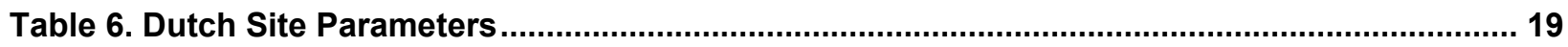

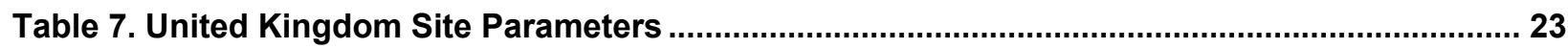

Table 8. Summary of U.K. Projects Expected for Commissioning in 2017-2018 ............................ 27

Table 9. Belgian Site Parameters .......................................................................................... 30

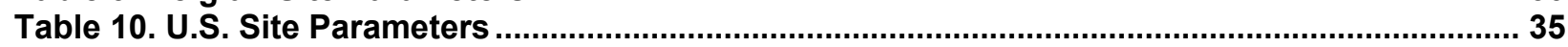

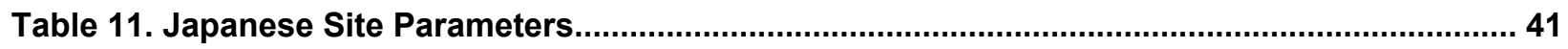

Table 12. Site Parameters for All Countries in the Study ............................................................. 46

Table 13. Financial Inputs Summary ..................................................................................... 49

Table 14. CAPEX and OPEX Comparison for All Countries in the Study ..................................... 53

Table 15. Energy Output of Representative Sites in Each Country ................................................54 


\section{Introduction}

\subsection{Background}

Task 26 "Cost of Energy" has been running within the International Energy Agency (IEA) Wind Technology Collaboration Programme since 2009. In 2015, task participants produced IEA Wind Task 26: Offshore Wind Farm Baseline Documentation (Smart et al. 2016), published in 2016 to document the technical and cost assumptions and levelized cost of energy (LCOE) results for a generic, geographically nonspecific, baseline offshore wind farm being commissioned in 20122014. This report has been prepared to document changes to offshore wind costs and technology since the baseline and as an analysis of the drivers of LCOE between countries. This report examines the physical site characteristics, technology choices, and regulatory context driving LCOE in key countries for offshore wind farms being commissioned in 2017-2018.

\subsection{Methodology}

Technology and cost assumptions have been compiled based on participants' knowledge of projects being developed and via publicly available data. The detailed cost and performance buildup for each project has been estimated using a shared Microsoft Excel cost model (hereafter referred to as "Cost Model") and LCOE modelling has been conducted using a shared Microsoft Excel cash flow model (hereafter referred to as "Cash Flow Model") developed within Task 26. Both models use assumptions and functions agreed upon between participants.

The analysis of each country included in this report follows the same methodology as shown in Figure 1.

Country-specific assumptions have been applied one by one to capture the individual impact on LCOE of site characteristics (e.g., wind speed, water depth, and distance from shore), technology choice (e.g., turbine rating, foundation type, and array cable type) and regulatory environment (e.g., cost of capital, tax, socialised development and/or transmission costs, and other regulatory charges). These impacts are shown in the order they have been applied in a waterfall chart for each country. Some variables have indirect impacts, for example, increasing the turbine rating (whilst keeping overall wind farm capacity constant) reduces the number of foundations and array cables that need to be installed and additionally reduce the expected project management cost. This interdependence is evaluated further in Section 9.

It should be noted that the technology selection for each of the country's representative sites may have significant impacts on LCOE. There are various reasons for a specific technology choice for each country's representative site including local supply chain considerations and capability, a preferred technology that a wind project developer is comfortable with, or potential regulatory and environmental constraints. For these various reasons the estimated LCOE for each country should not be compared between countries but instead used to identify how costs change within the unique conditions of each country individually. Moreover, given both the maturity and the dynamic nature of the offshore wind industry today it is important to note that the results presented here are a function of the inputs and assumptions applied for each site and country specific analysis. There is significant uncertainty in these assumptions and with alternative sites and technology solutions that could be applicable in a given country as well as continued market maturation it is expected that individual project costs will deviate from those reported here. 
During the analysis for this report Belgium and the Netherlands did not have active participants in the task group; however, the authors felt these countries were relevant to the study. The representative sites for these countries were developed using the same method of reflecting 2017-2018 sites; however, there is less insight available on detailed market analysis related to those sites in this report.

\section{Site Conditions}

Actual sites being commissioned in 2017-2018 were identified and their key characteristics documented. Based on this, a representative site was chosen for each country analysis. Where no sites are being commissioned in the 2017-2018 window, the representative site was defined based on participants' best knowledge of planned or potential projects in the near future.

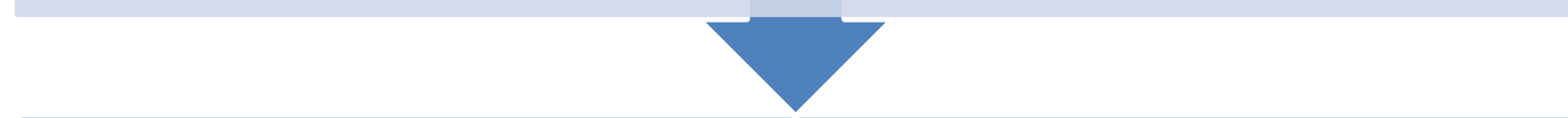

\section{Financial Framework}

Participants defined key financial and tax assumptions specific to each country. This includes tax rate, debt ratio, cost of debt, and cost of equity. The key country-specific assumptions are documented in each chapter.

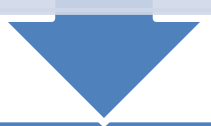

\section{Cost Assumptions}

The capital expenditure (CAPEX) and operating expenditure (OPEX) is estimated centrally using a spreadsheet model developed by ORE Catapult with verification/input from National Renewable Energy Laboratory (NREL),

SINTEF, LIFES50. The costs are applied in the same way for all countries. The CAPEX and OPEX estimates are based on country-specific site characteristics, such as water depth, distance from installation port, distance from operation and maintenance (O\&M) port, wave climate and foundation type.

\section{Annual Energy Production}

Annual energy production at each country representative site is estimated using the Danish Technical University (DTU) WAsP model. The WAsP software suite is the industry standard for wind resource

assessment, siting, and energy yield calculation for wind turbines and wind farms using Rayleigh distribution of power curves. For this study, the software has been used to calculate a mean wind speed for each site and site wake losses, using power curves of known models at each turbine rating.

\section{LCOE Calculation}

LCOE is computed using the TKI cash flow model. The same LCOE model was used for the IEA Wind Task 26: Offshore Wind Farm Baseline Documentation report (Smart et al. (2016).

Figure 1. Overview of methodology 


\subsection{Update to 2016 Baseline}

A new, detailed cost model was developed for this study to estimate the impact on LCOE of country-specific factors based on bottom-up assumptions. As a result, assumptions vary slightly from the previous cost breakdown in the IEA Wind Task 26: Offshore Wind Farm Baseline Documentation report (Smart et al. 2016) (Outlined in Table 1 and Table 2). The offshore wind generic baseline LCOE documented in the 2016 report estimated LCOE as $€ 146 /$ megawatt-hour (MWh) (Real 2014). This figure has been revised to reflect an up-to-date estimate of LCOE for the same site being commissioned in 2016/2017 based on movements in costs since 2016. Keeping the site characteristics unchanged, costs and financial assumptions were updated to reflect real-world developments since 2014.

Table 1. Update on Baseline Capital Expenditure (CAPEX) Figures (2016-2017)

\begin{tabular}{|c|c|c|}
\hline Description & $\begin{array}{c}2016 \text { Baseline }^{2} \\
\text { €/kilowatt } \\
\text { (kW) }\end{array}$ & $\begin{array}{c}2017 \text { Baseline } \\
€ / k W\end{array}$ \\
\hline Turbine supply & 1,496 & 1,300 \\
\hline Turbine installation and commissioning & 157 & 162 \\
\hline Turbines Subtotal & 1,653 & 1,462 \\
\hline Foundations supply & 577 & 551 \\
\hline Foundations installation & 279 & 210 \\
\hline Foundations Subtotal & 856 & 762 \\
\hline Array cable supply & 103 & 43 \\
\hline Array cable installation & 115 & 117 \\
\hline Offshore substation & 168 & 185 \\
\hline Export cable supply & 124 & 138 \\
\hline Export cable installation & 79 & 62 \\
\hline $\begin{array}{l}\text { Land-based substation and grid } \\
\text { connection }\end{array}$ & 79 & 93 \\
\hline Electrical Infrastructure Subtotal & 668 & 638 \\
\hline Construction insurance & 48 & 45 \\
\hline Project management & 126 & 145 \\
\hline Contingency & 318 & 305 \\
\hline Other CAPEX Subtotal & 493 & 496 \\
\hline Total Construction CAPEX & 3,670 & 3,357 \\
\hline Development & 119 & 101 \\
\hline Grand Total & 3,789 & 3,459 \\
\hline
\end{tabular}

\footnotetext{
${ }^{2}$ New cost categories have been used in the 2017 model. Data for 2015 have been reassigned to these new categories.
} 
These updates include:

- Indexation of the base year from 2014 to 2016

- Increased competition in turbine supply

- Reduced demand from oil and gas projects for vessels leading to lower vessel rates

- Optimised array cable layout and cable sizing and lower per-unit cable costs

- Reduced time spent on major turbine repairs.

The updates resulted in a revised generic baseline LCOE of $€ 130 / \mathrm{MWh}$ (real 2016), which is shown in each of the country-specific waterfall charts throughout this report.

Table 2. Update on Baseline Operational Expenditure (OPEX) Figures (2016-2017)

\begin{tabular}{|lcc|}
\hline Description & $\begin{array}{r}2016 \text { Baseline } \\
€ / \mathrm{kW}\end{array}$ & $\begin{array}{r}2017 \text { Baseline } \\
€ / \mathrm{kW}\end{array}$ \\
\hline Fixed operating costs & 30.4 & 28.3 \\
\hline Variable costs & 67.5 & 48.6 \\
\hline $\begin{array}{l}\text { Total Operation and Maintenance } \\
\text { (Preventive and Corrective) }\end{array}$ & $\mathbf{9 7 . 9}$ & $\mathbf{7 6 . 9}$ \\
\hline
\end{tabular}

\subsection{Beyond 2017-2018}

It is crucial to note that the analysis included in this report is intended to reflect the LCOE for offshore wind projects being commissioned in 2017-2018. Much of the publicity surrounding offshore wind relates to auction results or cost estimates for wind farms to be commissioned in the 2020s. It is natural that the LCOE estimates for current projects should be higher than these future prices, which are more frequently quoted in the public domain. Section 10 of this report provides an overview of some of the key technology innovations and other factors expected to be significant drivers in enabling these cost reductions. 


\section{Denmark}

\subsection{Sites Being Commissioned in 2017-2018}

Denmark does not have any offshore wind farms to be commissioned in 2017 or 2018. The most recent offshore project that went into operation in 2012 is Anholt, operated by the largest Danish utility Ørsted. Anholt consists of 111 turbines with a total capacity of 399.6 megawatts (MW).

The next offshore wind farm to be commissioned is Horns Rev 3. The project must be commissioned before January 1, 2020. It will be operated by Vattenfall and consist of 49 turbines with a total capacity of $406.7 \mathrm{MW}$. The maximum export capacity, however, is $400 \mathrm{MW}$ and so the fully built-out capacity will include an element of reserve.

By the end of 2020, Vattenfall will also establish two additional projects closer to shore. The farms Vesterhav Syd and Vesterhav Nord will be placed around 4 to 10 kilometres $(\mathrm{km})$ outside of the Danish west coast. They will have capacities of $170 \mathrm{MW}$ and $180 \mathrm{MW}$. In total, 41 turbines of the 8-MW class (direct-drive technology) will be installed.

In the Baltic Sea, Vattenfall won the tender to establish the offshore wind farm at Kriegers Flak. This project is to be commissioned by 2022. Total capacity will be $605 \mathrm{MW}$, consisting of 72 turbines of the 8-MW class (direct-drive technology).

The Danish Energy Agency has granted a number of permissions for preliminary investigations in near-shore areas, including Omø Syd, Jammerland Bugt, Mejl Flak, and Lillebælt Syd. Further tenders have not been announced. The Danish transmission system operator, however, does expect more developments of 600-MW wind farms, similar in size to Kriegers Flak. In their 2017 assumptions, an additional $600 \mathrm{MW}$ is scheduled to come online in each of the following years: 2027, 2030, 2033, 2036, and 2039. Four of these farms are expected in the North Sea. The fifth project is related to repowering the Rødsand wind farms in the Baltic Sea.

The representative site has been chosen based on the closest in terms of commissioning date and its location at the North Sea, where most of the offshore development will take place.

Table 3. Danish Site Parameters

\begin{tabular}{|c|c|c|c|}
\hline Country & & \multirow{2}{*}{$\begin{array}{c}\text { Denmark } \\
\text { Representative }\end{array}$} & Denmark \\
\hline Parameter & Units & & Horns Rev 3 \\
\hline Mean wind speed & Metres per second/s & 9.57 & 9.94 \\
\hline $\begin{array}{l}\text { Height for mean wind speed } \\
\text { measurement }\end{array}$ & metres (m) & 105 & 105 \\
\hline Average water depth & $\mathrm{m}$ & 16 & 16 \\
\hline Distance to construction port & $\mathrm{km}$ & 60 & 50 (Hvide Sande) or 60 \\
\hline Distance to O\&M port & $\mathrm{km}$ & 50 & (Esberg) \\
\hline Distance to cable landfall & $\mathrm{km}$ & 33 & 33 \\
\hline Export cable numbers & $\#$ & 1 & 2 \\
\hline Onshore cable length & $\mathrm{km}$ & 50 & 50 \\
\hline Number of offshore substations & & 1 & 1 \\
\hline Turbine expected & model & V164-8.0 & V164-8.0 \\
\hline Hub height expected & $\mathrm{m}$ & 105 & 102 \\
\hline Turbine numbers & $\#$ & 50 & 49 \\
\hline Capacity & MW & 400 & 406.7 \\
\hline Foundation expected & type & monopile & monopile \\
\hline Array cable rating expected & kilovolt & 33 & 33 \\
\hline
\end{tabular}




\subsection{Representative Country Site}

\subsubsection{Assumed Location}

The analysis is based on a representative site commissioned in the time frame of 2017-2018. As stated earlier, no Danish offshore wind farm matches these criteria. The project closest in terms of commissioning date is Horns Rev 3, which is located off the western coast of Jutland in the North Sea (Figure 2), and this site has been chosen as representative of the offshore development in Denmark. The construction is to be finalised by the end of 2019, and the technical parameters are therefore well known.

Choosing a location in the North Sea that represents offshore development in the whole country might be challenged as being misleading. For example, other big projects are located in Kategat (e.g., Anholt) or the Danish part of the Baltic Sea (e.g., Kriegers Flak), where wind conditions are different. As these other farms were commissioned some time ago, or only will be commissioned further ahead in the future and the design and choice of turbines is not yet known, the North Sea site is regarded as most representative of near-term wind farm development.

Moreover, future developments are also expected to be located in the North Sea to a large extent.

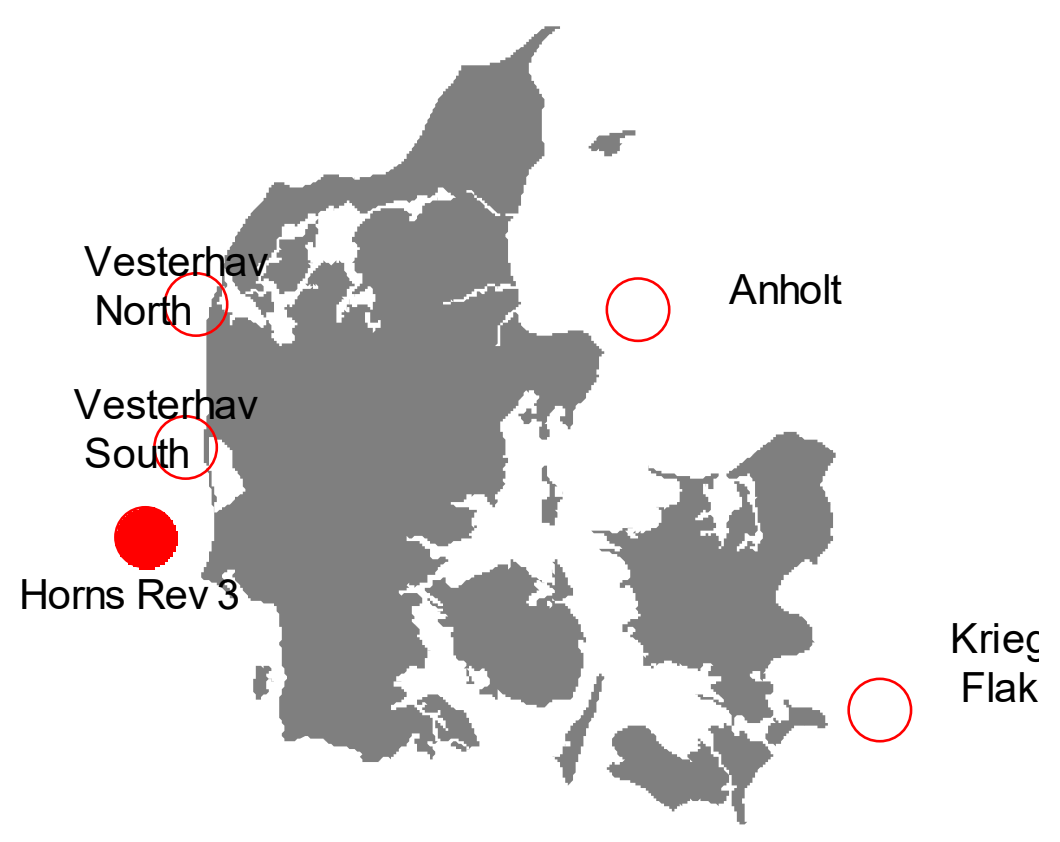

Figure 2. Danish offshore wind sites

\subsubsection{Site Parameters}

Parameters for the selected Danish offshore wind site include the following:

- Water depth. The turbines at Horns Rev 3 will be installed at water depths between 11 and 19 metres $(\mathrm{m})$.

- Distance from shore. The distance to shore is between 29 and $44 \mathrm{~km}$. Both the ports of Hvide Sande (around $50 \mathrm{~km}$ from the wind farm) and the port of Esbjerg (around $60 \mathrm{~km}$ from the wind farm) are used during the construction phase. The port of Esbjerg will also be the operation and maintenance (O\&M) base for the wind farm. Hvide Sande had been discussed as the O\&M base as well and it was chosen as the basis for representative site calculations in this modelling because of the shorter distance. 
- Mean wind speed. The mean wind speed at Horns Rev 2 is estimated to be 9.57 metres per second $(\mathrm{m} / \mathrm{s})$ at the hub height of $105 \mathrm{~m}$. This translates to a wind speed of $9.57 \mathrm{~m} / \mathrm{s}$ at a $100-\mathrm{m}$ hub height. The capacity factor is estimated at $45.86 \%$.

\subsubsection{Technology Parameters}

Technology parameters for the selected Danish offshore wind project include the following:

- Turbine rating. The operator Vattenfall has announced it will use MHI Vesta's V1648.0-MW turbines, with rated power boosted to $8.3 \mathrm{MW}$. Hub height is $105 \mathrm{~m}$ and rotor diameter is $164 \mathrm{~m}$. A total number of 49 turbines are planned to be installed to achieve a total capacity of $406.7 \mathrm{MW}$. As the maximum export capacity is defined to be $400 \mathrm{MW}$, for the purpose of the representative calculations, we use 50 turbines with a capacity of 8 MW per turbine.

- Foundation type. The foundations will be monopiles that are driven 25-39 m into the seabed.

- Array cables. The array cables operate at 33 kilovolts $(\mathrm{kV})$, which is transformed to 220 $\mathrm{kV}$ at the transformer station for further transmission.

\subsection{Finance and Tax Background}

\subsubsection{Debt Ratio}

The cost of capital for Denmark is based on the assumption that risk is toward the low end of the scale for equity providers and lenders because of the Danish transmission system operator (TSO) undertaking some of the development of the wind farm and more importantly the supply and installation of the offshore substation and export cable. This transfer of responsibility significantly reduces the risk borne by wind farm owners and lenders and may also influence the debt ratio of the project by increasing the leverage provided by lenders. However, the actual cost of equity for any project is not disclosed. For the purpose of the LCOE analysis, we assume a typical debt share of $70 \%$.

\subsubsection{Cost of Debt}

The debt structure is specific to each project and can vary from owners fully self-financing their project (100\% equity) or bank consortia including commercial banks, export agencies, and other institutions, such as the European Investment Bank. We assume a traditional project finance structuring with nonrecourse long-term financing for an offshore project with a contract for difference (CfD) revenue scheme (e.g., the Gemini Project in the Netherlands [Cherrier 2014]) with a fixed interest rate of $4.75 \%$. Loan maturities are normally equal or lower than the period of secure revenues (50,000 full-load hours under the current Danish subsidy regime) as lenders seek to mitigate unforeseen events to cover for any gaps. We assume a tenor of 13 years in line with the estimated period to reach 50,000 full-load hours for the representative site.

\subsubsection{Cost of Equity}

The cost of equity should also reflect the risk perception of equity providers. Therefore, the overall weighted average cost of capital (WACC) of an offshore wind farm should be lower in comparison to previous estimates with higher cost of debt and higher risks perceived by investors. Based on the WACC approach, we assume a return on equity to be around $12.75 \%$ because of more confidence in offshore projects and current attractive long-term financing 
conditions. This cost of equity results in a WACC of $6.42 \%$ (debt share $70 \%$, cost of debt $4.75 \%$, cost of equity $12.75 \%$ and corporate tax $22 \%$ ).

\subsubsection{Tax}

In Denmark, offshore assets can be depreciated at $15 \%$ on a declining balance method for tax purposes. The nominal corporate income tax rate amounts to $22 \%{ }^{3}$

\subsection{Regulatory Regime}

\subsubsection{Revenue Support}

The revenue support for electricity production from renewable energy is based on the Promotion of Renewable Energy Act. Although onshore wind receives a fixed premium for produced electricity (from 2018 onward tendered out through a multitechnology an auction scheme), offshore wind producers are supported by a floating premium that effectively resembles a fixed feed-in tariff. The support level is determined specifically for each site through separate tenders. The tendering process is organized by the Danish Energy Agency.

As the tenders are carried out separately, the conditions for various projects can differ slightly. Starting with the tender for the Anholt wind farm, for example, there are no support payments in situations of negative electricity prices in the spot market. This reduces the revenues of the energy eligible for support, if the offshore power plant generates electricity during these hours. The amount eligible for support is set for in the individual tenders such that it covers for approximately 50,000 full load hours. ${ }^{4}$

The tenders for offshore wind in Denmark have resulted in the following levels shown in Table 4.

${ }^{3}$ http://www.skm.dk/skattetal/statistik/generel-skattestatistik/selskabsskattesatser-i-eu-landene

${ }^{4}$ For a power plant with a $40 \%$ capacity factor, the eligible support would amount to approximately 14 years. 
Table 4. Results of Danish Offshore Wind Farm Tender Rounds

\begin{tabular}{|c|c|c|c|c|}
\hline Project Name & Tender Date & Price & $\begin{array}{l}\text { Tendered } \\
\text { Capacity }\end{array}$ & $\begin{array}{l}\text { Support } \\
\text { Duration }\end{array}$ \\
\hline Horns Rev 2 & February 2005 & $\begin{array}{l}51.8 \text { øre/kilowatt- } \\
\text { hours (kWh) } \\
\text { (approximately } \\
€ 69 / \mathrm{MWh} \text { ) }\end{array}$ & $200 \mathrm{MW}$ & $\begin{array}{l}10 \text { terawatt- } \\
\text { hours (TWh) }\end{array}$ \\
\hline Rødsand 2 & April 2008 & $\begin{array}{l}\text { 62.9 øre/MWh } \\
\text { (approximately } \\
€ 84 / \mathrm{MWh} \text { ) }\end{array}$ & $200 \mathrm{MW}$ & $10 \mathrm{TWh}$ \\
\hline Anholt & April 2010 & $\begin{array}{l}\text { 105.1 øre/kWh } \\
\text { (approximately } \\
€ 141 / \mathrm{MWh} \text { ) }\end{array}$ & $390-400 \mathrm{MW}$ & $20 \mathrm{TWh}$ \\
\hline Horns Rev 3 & February 2015 & $\begin{array}{l}77.0 \text { øre/kWh } \\
\text { (approximately } \\
€ 103 / \mathrm{MWh} \text { ) }\end{array}$ & $390-410 \mathrm{MW}$ & $20 \mathrm{TWh}$ \\
\hline Vesterhav South & $\begin{array}{l}\text { September } \\
2016\end{array}$ & $\begin{array}{l}\text { 47.5 øre/kWh } \\
\text { (approximately } \\
€ 64 / \mathrm{MWh} \text { ) }\end{array}$ & $\begin{array}{l}\text { up to } 200 \\
\text { MW5 }\end{array}$ & 8.5 TWh \\
\hline Vesterhav North & $\begin{array}{l}\text { September } \\
2016\end{array}$ & $\begin{array}{l}\text { 47.5 øre/kWh } \\
\text { (approximately } \\
€ 64 / \mathrm{MWh} \text { ) }\end{array}$ & up to $200 \mathrm{MW} 5$ & 9 TWh \\
\hline Kriegers Flak & $\begin{array}{l}\text { November } \\
2016\end{array}$ & $\begin{array}{l}37.2 \text { øre/kWh } \\
\text { (approximately } \\
€ 50 / \mathrm{MWh} \text { ) }\end{array}$ & $590-610 \mathrm{MW}$ & $30 \mathrm{TWh}$ \\
\hline
\end{tabular}

Two of the recent tenders have been defined as nearshore. These farms are located closer to shore and the project developer has to connect the wind farm to the closest connection point onshore.

Public authorities carry out extensive preinvestigations, including an environmental impact assessment, prior to putting these selected sites through the tendering procedure. However, the costs for these studies will later have to be reimbursed by the winning applicant. An alternative to the tendering procedure exists in the so-called open-door procedure. As part of this procedure, a developer may apply for the right to carry out preliminary investigations for a site that has not been reserved for tendering. The Danish Energy Agency has done a screening and published a list of sites that are eligible for wind development. The export cable and grid have to be established by the project developer and the support payments are similar to those of onshore wind (i.e., a fixed premium of 250 Danish krones/MWh), capped whenever the total settlement price (market price + premium) reaches 580 Danish krones/MWh; in addition, a compensation of 23 Danish krones/MWh is paid for balancing. This procedure was most relevant for projects close to shore. For example, a 21-MW nearshore farm in the Great Belt between Zealand and Funen has been established on the basis of the open-door procedure. As mentioned earlier, the general fixed-premium support scheme has been phased out, and applies only to installations

\footnotetext{
${ }^{5}$ As part of a multisite nearshore tender of $350 \mathrm{MW}$.
} 
commissioned before February 2018. Onshore support levels are now being found through multitechnology tendering.

\subsubsection{Development and Consent}

For offshore sites under tendering, public authorities conduct the preliminary investigation. The Danish Energy Agency under the Ministry of Energy coordinates the planning process for all involved authorities. This coordination should ensure that the project is developed in agreement with different interests.

As part of the preliminary assessment, the Danish TSO Energinet is responsible for producing an environmental impact assessment covering the offshore wind farm and grid connection. The study is based on a worst-case scenario (i.e., the most harmful impact). It will, therefore, not be required by any winning developer to do an additional assessment. Preliminary investigations also include an analysis of wind conditions and meteorological ocean and geological conditions.

Additionally, offshore wind developers need to acquire several permits:

- A license for carrying out preliminary investigations

- A license to establish the offshore wind turbines subject to an environmental impact assessment

- A license to exploit wind power for a given number of years

- Approval to generate electricity.

All of these licenses are provided through the Danish Energy Agency.

\subsubsection{Transmission}

Typically, the TSO will be responsible for building and owning the offshore substation and export cables. Moreover, the grid should be extended in due time to be able to absorb the electricity generated by the offshore wind farm. These measures are fully paid for by the grid operator.

For projects defined as nearshore or projects under the open-door procedure, the developer is responsible for the grid connection at the closest onshore substation. The grid operator will still be responsible for strengthening the existing grid where necessary.

\subsubsection{Regulatory Charges}

The offshore wind farm operators are responsible for selling their production on the electricity market. Any imbalance costs that may occur because of forecast errors or unplanned outages are borne by the operator.

Electricity producers pay a transmission charge to the TSO. The concession agreements of the offshore wind farms, however, include clauses that ensure reimbursement of the tariff to the operators. These fees will therefore not impact the wind farm operator.

\subsection{Country-Specific LCOE}

Figure 3 presents a waterfall chart illustrating the impact of each of these categories on LCOE. The LCOE of the 2016 baseline is on the left followed by the reduction associated with the updated costs to bring the baseline in line with 2017 project LCOE. Denmark sees lower average CAPEX as a result of the shallower water depths in Denmark as well as the adoption of 
technology development that explains the changes seen in comparison to the 2016 baseline. The Danish site with generic regulatory inputs LCOE is $€ 130 / \mathrm{MWh}$. Notably, the transmission system investment by the TSO and development cost borne by the government energy agency additionally reduce LCOE. As expected, the relatively low cost of financing also contributes to the final LCOE of $€ 91.79 / \mathrm{MWh}(\$ 106 / \mathrm{MWh})$.

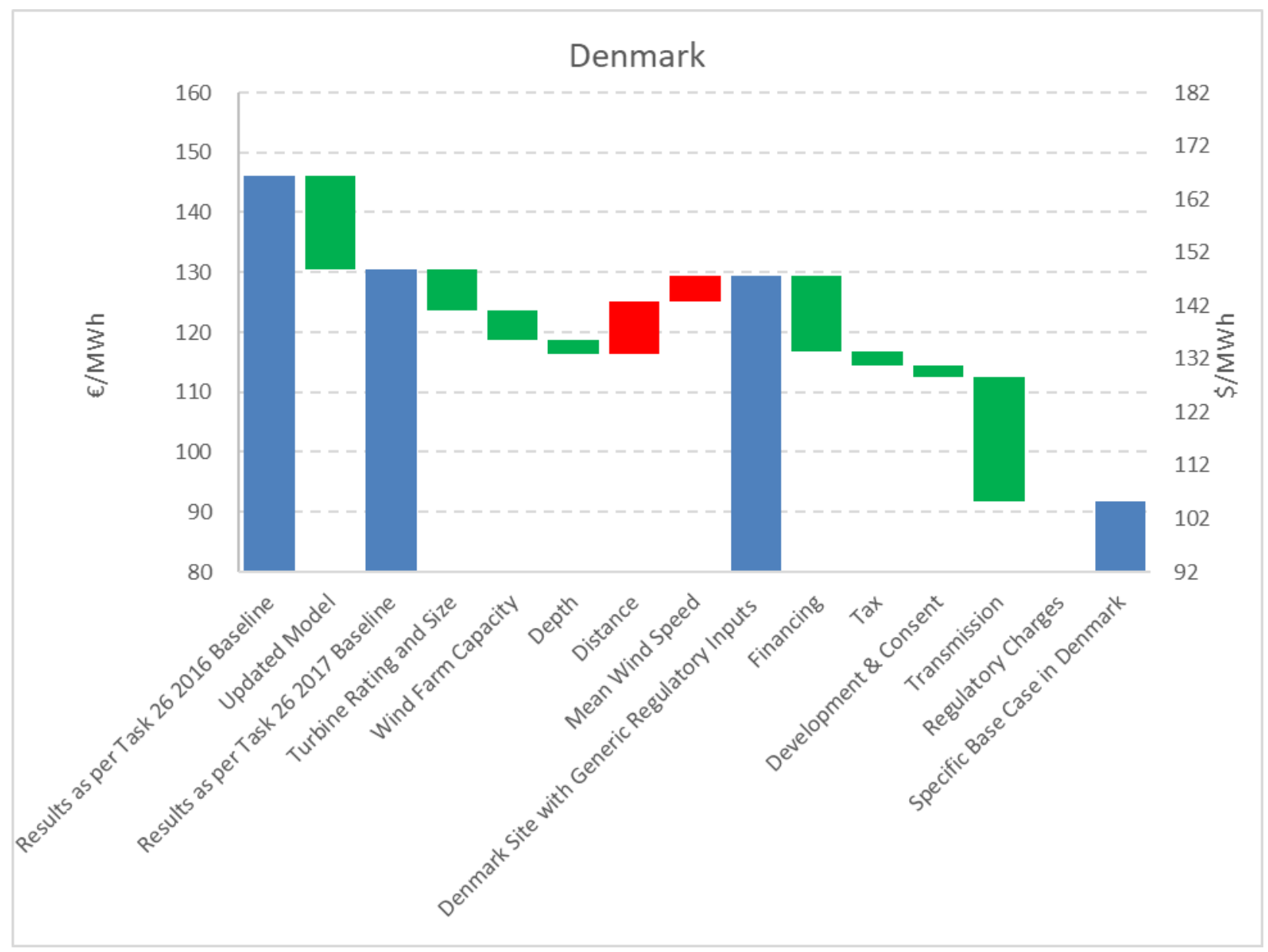

Figure 3. Waterfall chart of Danish representative site 


\section{Germany}

\subsection{Sites Being Commissioned in 2017-2018}

All wind farms being commissioned in 2017 and 2018 are in the German North Sea except for Wikinger, which is the only wind farm to become operational in the Baltic Sea during this period (Table 5). However, site conditions in the North Sea differ substantially in terms of water depth and distance to shore.

Table 5. German Site Parameters

\begin{tabular}{|c|c|c|c|c|c|c|c|c|}
\hline Country & & Germany & Germany & Germany & Germany & Germany & Germany & Germany \\
\hline Parameter & Units & $\begin{array}{l}\text { Representativ } \\
\text { e }\end{array}$ & Merkur & Nordergrunde & $\begin{array}{l}\text { Nordsee } \\
\text { One }\end{array}$ & Sandbank & Veja Mate & Wikinger \\
\hline $\begin{array}{l}\text { Mean wind speed } \\
\text { Height for mean } \\
\text { wind speed }\end{array}$ & $\mathrm{m} / \mathrm{s}$ & 9.47 & 9.92 & 9.95 & 9.89 & 10.08 & 10.03 & 8.64 \\
\hline measurement & $\mathrm{m}$ & 100 & 100 & 100 & 100 & 100 & 100 & 100 \\
\hline $\begin{array}{l}\text { Average water depth } \\
\text { Distance to }\end{array}$ & $\mathrm{m}$ & 35 & 30 & 4 & 27 & 30 & 39 & 38 \\
\hline $\begin{array}{l}\text { construction port } \\
\text { Distance to O\&M }\end{array}$ & $\mathrm{km}$ & 80 (Eemshaven) & 60 & $\begin{array}{l}17 \\
22\end{array}$ & 44 & 110 & 114 & 39 \\
\hline $\begin{array}{l}\text { port } \\
\text { Distance to cable }\end{array}$ & $\mathrm{km}$ & 60 (Norddeich) & & (Hooksiel) & & & 146 (Emden) & 51 (Sassnitz) \\
\hline $\begin{array}{l}\text { landfall } \\
\text { Export cable }\end{array}$ & $\mathrm{km}$ & 60 & 12 & 28 & 7 & 36 & 11 & 90 \\
\hline $\begin{array}{l}\text { numbers } \\
\text { Land-based cable }\end{array}$ & $\#$ & 1 & 2 & 1 & 2 & 2 & 2 & 2 \\
\hline length & $\mathrm{km}$ & 60 & N/A & 4 & N/A & N/A & N/A & \\
\hline $\begin{array}{l}\text { substations } \\
\text { Turbine expected }\end{array}$ & & $\frac{1}{\text { generic }}$ & $\frac{1}{\text { Haliade } 150}$ & $\frac{1}{6.2 \mathrm{M} 126}$ & $\frac{1}{6.2 \mathrm{M} 126}$ & $\frac{1}{\text { SWT-4.0-130 }}$ & $\frac{1}{\text { SWT-6.0-154 }}$ & $\frac{1}{\text { AD 5-135 }}$ \\
\hline $\begin{array}{l}\text { Turbine expected } \\
\text { Hub height expected }\end{array}$ & $\begin{array}{c}\text { model } \\
\mathrm{m}\end{array}$ & $\begin{array}{l}\text { generic } \\
95\end{array}$ & $\begin{array}{c}\text { Haliade } 150 \\
102.6\end{array}$ & $\begin{array}{c}6.2 \mathrm{M} 126 \\
97\end{array}$ & $\begin{array}{c}6.2 \mathrm{M} 126 \\
100\end{array}$ & $\begin{array}{l}\text { SWT-4.0-130 } \\
80\end{array}$ & $\begin{array}{c}\text { SWT-6.0-154 } \\
104\end{array}$ & $\begin{array}{c}\text { AD } 5-135 \\
97.5\end{array}$ \\
\hline Turbine numbers & $\#$ & 60 & 66 & 18 & 54 & 72 & 67 & 70 \\
\hline Capacity & $\mathrm{MW}$ & 360 & 396 & 110.7 & 332.1 & 288 & 402 & 350 \\
\hline $\begin{array}{l}\text { Foundation expected } \\
\text { Array cable rating }\end{array}$ & type & monopile & monopile & monopile & monopile & monopile & monopile & jacket \\
\hline expected & kV & 33 & 33 & 33 & 33 & 33 & 33 & 33 \\
\hline
\end{tabular}




\subsection{Representative Country Site}

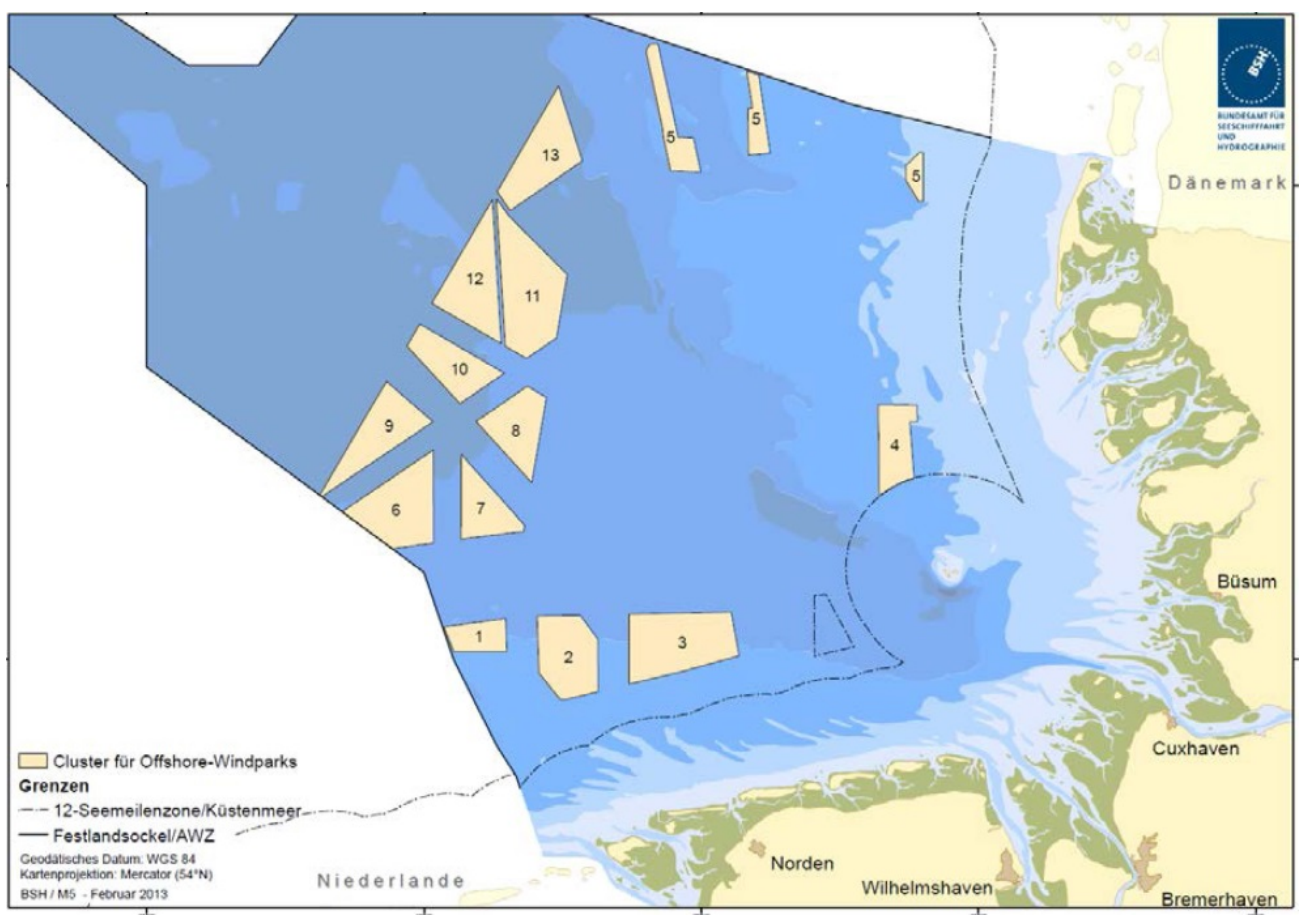

Figure 4. German offshore wind sites

(Source: German Maritime and Hydrography Agency [BSH])

\subsubsection{Assumed Location}

The assumed location represents site conditions in the German North Sea clusters 1 to 3 (Figure 4). These clusters have the smallest distance to shore and have been main areas of installations in the years from 2016 to 2018. In cluster 2, development started with the installation of the FINO 1 meteorological mast in 2003 and subsequently the installation and commissioning of the pioneering wind farm Alpha Ventus in 2009.

The selected site conditions bear the closest resemblance to the wind farms Nordsee One and Merkur. In terms of water depth and distance to shore, the conditions are also similar to the Baltic Sea wind farm Wikinger. However, AC grid connections and different seabed conditions with jacket foundations have to be considered.

\subsubsection{Site Parameters}

Parameters for the German offshore wind sites include the following:

- Water depth. The water depth assumed is $35 \mathrm{~m}$ and is an average of the Merkur and Wikinger conditions. The predominant support structures for all North Sea projects completed in the given period are monopiles.

- Distance from shore. The offshore clusters 1 to 3 are located $40 \mathrm{~km}$ north of the German island Borkum. Cluster 1 is adjacent to the Dutch border. The construction port for most of the projects is Eemshaven. Operation and maintenance is being done from the port of Norddeich. For the distances to the representative site, $80 \mathrm{~km}$ for construction and $60 \mathrm{~km}$ for O\&M work have been set. 
- Mean wind speed. The mean wind speed in the chosen clusters is available from the FINO 1 meteorological mast data since 2004. Mean wind speeds measured until 2009 have been between 9 and $10 \mathrm{~m} / \mathrm{s}$ at a 90-m height (Figure 5). From 2009 on, the measurements have been influenced by the wakes of Alpha Ventus. The mean wind speed of $9.47 \mathrm{~m} / \mathrm{s}$ at hub height modelled from the DTU WaSP model therefore is an adequate assumption for the representative site.
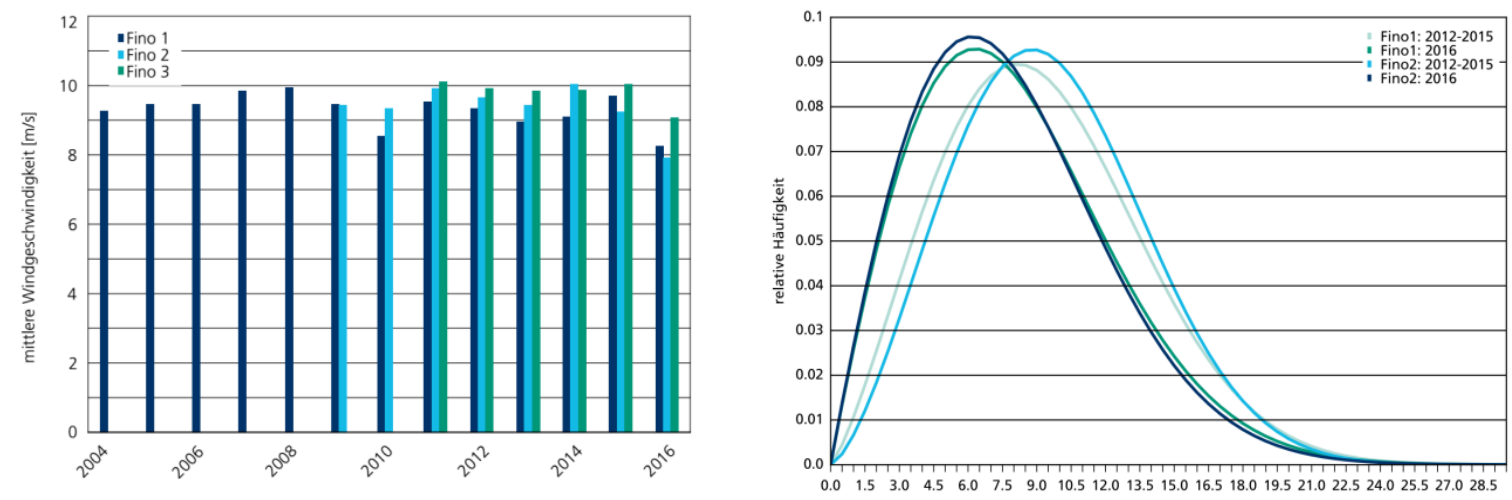

Figure 5. (Left) Wind speed distribution (2004-2012) at the meteorological mast FINO1 at the 90-m height and the (right) mean annual wind speed at FINO meteorological mast locations at the $90-\mathrm{m}$ height

(Sources: Fraunhofer IEE Wind Energy Report 2016 and BSH)

\subsubsection{Technology Parameters}

Technology parameters for the German offshore wind sites include the following:

- Turbine rating. The types of wind turbines to be deployed represent all major manufacturers from Adwen and Alstom/GE to Senvion and Siemens. The rated capacity of turbines ranges from $4 \mathrm{MW}$ to $6 \mathrm{MW}$, with four of the farms using turbines with $6 \mathrm{MW}$ and rotor diameters from 126 to $154 \mathrm{~m}$. As turbines in the 6-MW range supplied by GE Alstom, Senvion, and Siemens dominate in the realised projects, the rated capacity is assumed at $6 \mathrm{MW}$.

- Foundation type. As all North Sea projects use monopile foundations, this foundation type is also assumed in the representative site.

- Array cables. Array cables for all wind farms use 33-kV AC cables to connect to the converter platform. In terms of grid connections, Wikinger and the nearshore site Nordergründe will use AC connections, whereas all other sites are using high-voltage direct-current technology.

\subsection{Finance and Tax Background}

\subsubsection{Debt Ratio}

The financial assumptions are based on the Prognos/Fichtner study on cost reduction potential in Germany that proposed a $7.19 \%$ pretax WACC for projects with a commissioning date in 2017 (Hobohm et al. 2013). This number was broken down into a debt share of $65 \%$ with a $4.6 \%$ interest rate and $35 \%$ equity at $12 \%$ interest. Based on a financial expert review, we allowed an increased debt share of $75 \%$ with a cost of debt at $4 \%$, which leads to the assumed pretax WACC of $6.0 \%$. 


\subsubsection{Cost of Debt}

The interest rate on debt has been estimated at $4 \%$.

\subsubsection{Cost of Equity}

The return expectation on equity has been estimated at $12 \%$.

\subsubsection{Tax}

The corporate tax rate for Germany is $29.83 \%$. Depreciation for wind turbine assets is based on a 16-year straight-line scheme.

\subsection{Regulatory Regime}

There is a political target for installed offshore wind power capacity in the ErneuerbareEnergien-Gesetz (renewable energy act - German Bundestag 2016), which aims for construction of $6.5 \mathrm{GW}$ by 2020 , and $15 \mathrm{GW}$ by 2030 . All forms of renewable energy are subject to priority dispatch, which ensures that all renewable electricity can be fed into the grid or is compensated in the case of redispatch or curtailment.

\subsubsection{Revenue Support}

Wind farms built in Germany in 2017 and 2018 are subject to a feed-in-tariff support scheme, as shown in Figure 6, and this will continue for all projects that received a grid connection commitment before January 1, 2017 and are operational before January 1, 2021. For projects that become operational after that date, the European Union guideline for government environmental protection and energy grants enforces a tender auction.

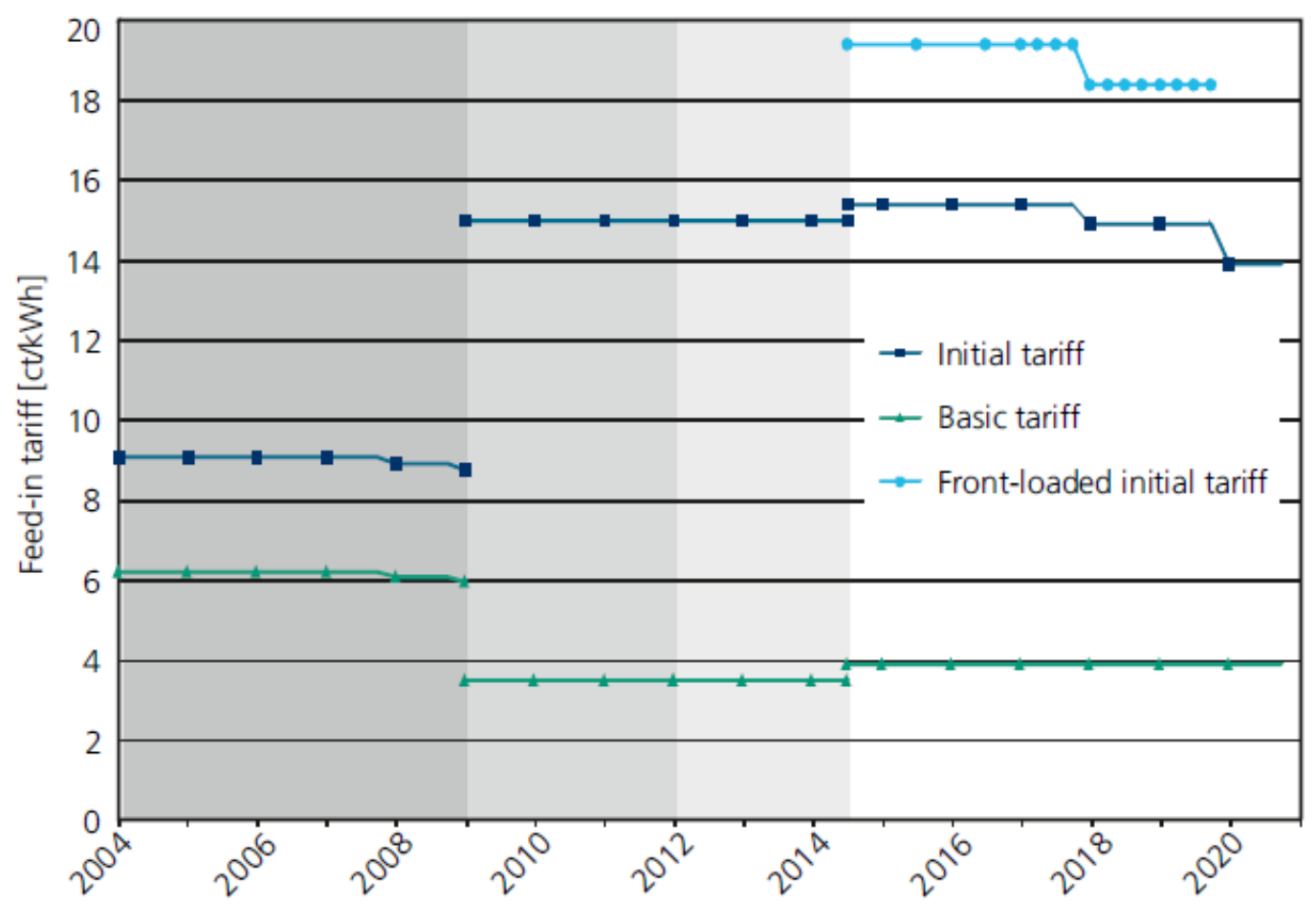

Figure 6. Time period of initial payment for offshore wind turbines in Germany (Renewable Energy Act 2014) 
As an accompanying measure, the state-owned KfW development bank put a special offshore wind energy programme into place in 2011 with a credit volume totalling $€ 5$ bn at market interest rates.

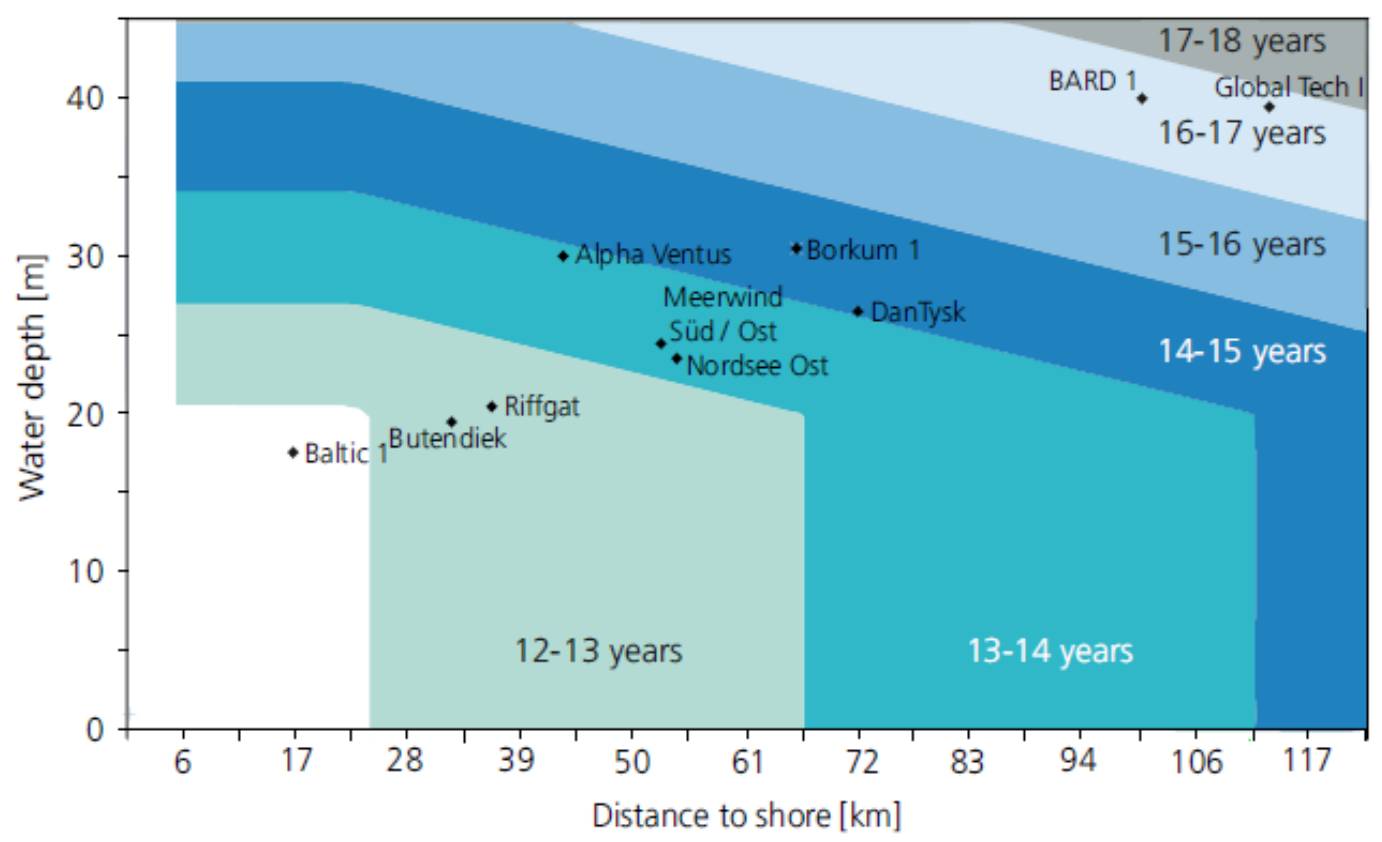

Figure 7. Feed-in payments for offshore electricity (Fraunhofer IEE Wind Energy Report 2017)

The feed-in-tariff is front loaded with higher payments in an initial period of 12 years with payments of $€ 154 / \mathrm{MWh}$ for farms being commissioned in 2017 and $€ 149 / \mathrm{MWh}$ in 2018 . This period can be increased depending on water depth and distance to shore (Figure 7). Farms in clusters 1-3 enjoy the higher payments for 13-14 years. The base remuneration thereafter is at $€ 39 / \mathrm{MWh}$ up to the $20^{\text {th }}$ year of operation. Furthermore, operators may alternatively opt for even more front loading, allowing them a payment of $€ 194 / \mathrm{MWh}$ (farms commissioned by 2017) or $€ 184 / \mathrm{MWh}$ (commissioned from 2018), respectively, for the first 8 years. This model is aimed at reducing the risks in financing and allow for better debt terms.

\subsubsection{Development and Consent}

The Federal Maritime and Hydrographic Agency is responsible for approval procedures in the German Exclusive Economic Zone, which is outside the 12-mile zone, according to the Marine Facilities Ordinance (SeeAnlV). This area is where most of the offshore development in Germany takes place.

The approval process has a defined course of steps and actions and includes conferences and consultations for other stakeholders, such as environmental protection organisations, commercial and small craft shipping, fisheries, and the public to review and comment on the proposed plan. Plans for offshore wind farms have to outline their impact on the marine environment and cannot endanger the safety or efficiency of shipping traffic or disrupt national defense interests.

Approvals for offshore wind farms include approval for a 25 -year period, the requirement to start building the installations within a certain period of time, requirements concerning safety and environmental protection measures, such as noise reduction in the construction phase, and a bank guarantee for the decommissioning of the wind turbines at the end of life. 
The German government usually prioritises approval for projects that will feed electricity to the grid the fastest. Here, the proximity to the shore and to power lines is a key aspect that is taken into account.

\subsubsection{Transmission}

The large number of offshore wind turbines requires grid expansion planning that incorporates ecological, economic, and physical influencing factors into the planning approach. Wind farms that are physically related are grouped into clusters. In the North Sea, 13 different clusters have been identified this way, and in the Baltic Sea another five. The standards for these collective connections are 900-MW high-voltage direct-current systems with a voltage of $320 \mathrm{kV}$.

The TSOs develop an offshore grid development plan for approval from the federal grid agency (BNetzA) on a biannual basis. Since August 2014, grid connection capacity is being allocated by the BNetzA in due consideration of all existing grid connection commitments and restricted to the offshore capacity target of $6.5 \mathrm{GW}$ by 2020 . Thereafter, this amount increases by $800 \mathrm{MW}$ every year. Meanwhile, a transitional regulation means $7.7 \mathrm{GW}$ can be allocated to meet the federal government's expansion goal of $6.5 \mathrm{GW}$ by 2020 . The BNetzA runs an assignment procedure for allocation in a 9-month cycle, provided connection capacity is still available.

The TSOs (TenneT and 50Hertz) are responsible for financing and realizing these investments into the offshore grid connections and are paid back by a system usage fee that is added on the electricity price. The BNetzA monitors the amount of this fee and allows for a reasonable return for the TSOs. Therefore, German offshore projects do not include transmission cost.

Moreover, significant risks related to the grid connections are insured by the German regulatory regime. The risk of a late realisation of grid connection is being offset by a law that introduced an additional fee on the electricity price as liability insurance for the TSOs in case of critical transmission project delays. The dispatch priority for renewable electricity eliminates the risk of lost production and income caused by curtailment for the operator as he is entitled to reimbursements for the lost income from the TSO, which, in turn, may add these costs on the system usage fee for the electricity customer.

\subsubsection{Regulatory Charges}

There are no additional regulatory charges imposed on wind farm operators in Germany.

\subsection{Country-Specific LCOE}

Figure 8 illustrates the impact of each of the previously mentioned categories on LCOE. In Figure 7, the LCOE of the 2016 baseline is on the left followed by the reduction associated with the updated costs to align the baseline with the 2017 project LCOE. As indicated in Section 3.2.2, it is evident in Figure 4 that the increased distance to shore for German offshore sites has a significant impact on LCOE. The Wadden Sea national park, with its rich and unique habitat, enforces all major offshore projects to be constructed $40 \mathrm{~km}$ or more from the coast, which leads to longer journeys for O\&M and reduces the accessibility of the turbines. The German site with generic regulatory input LCOE is $€ 155 / \mathrm{MWh}$.

On the regulatory side, LCOE is reduced in comparison to the baseline, by good financing conditions resulting from a low country risk, funding opportunities from the state-owned credit institute, and a higher leverage as a result of an increased debt ratio. 
The most significant reduction is the allocation of transmission cost via the TSOs and the system usage fee to the electricity consumers. Therefore, it is completely off the sheet of the offshore wind farm developers and operator. The final LCOE is $€ 99 / \mathrm{MWh}(\$ 114 / \mathrm{MWh})$.

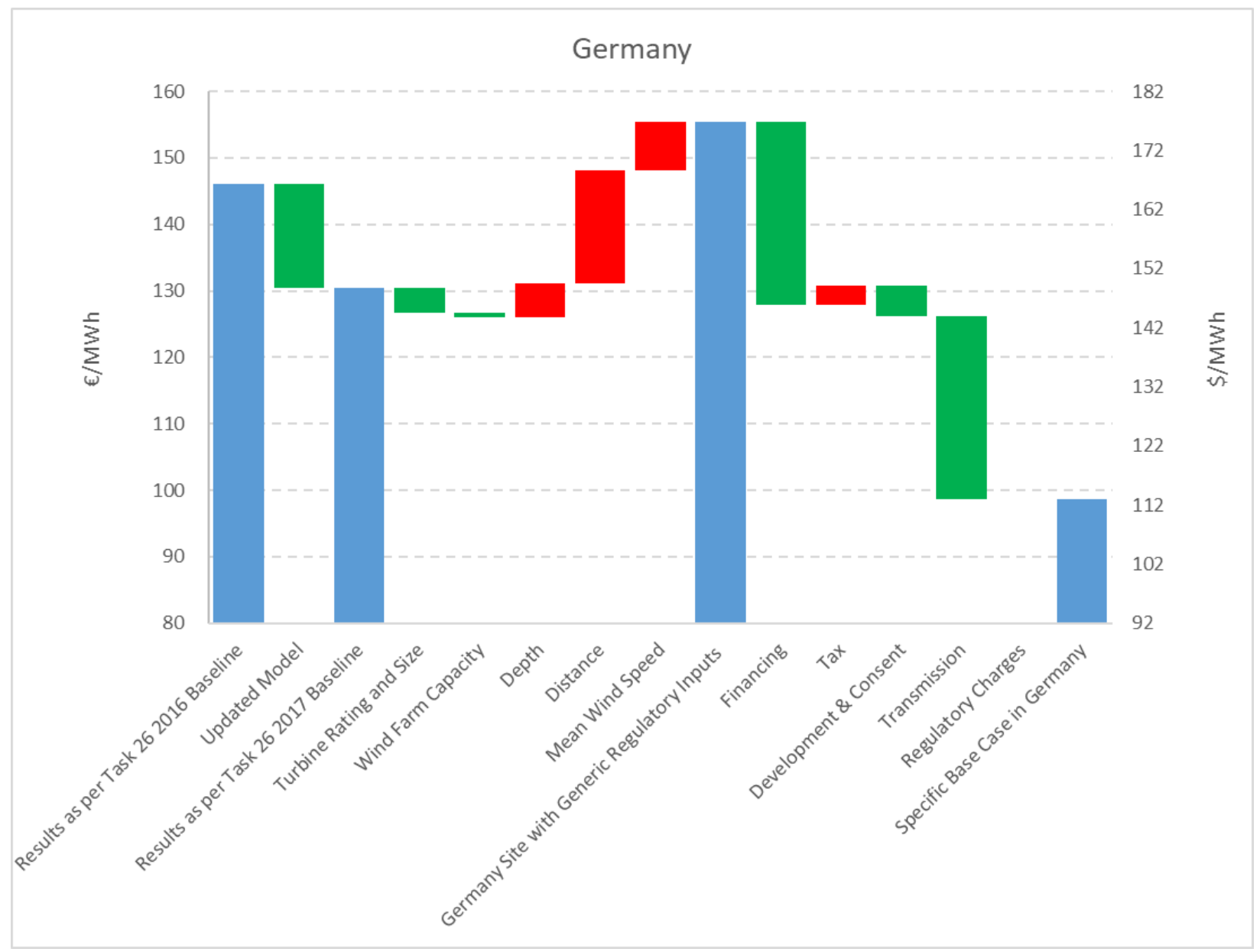

Figure 8. Waterfall chart of German representative site 


\section{Netherlands}

\subsection{Sites Being Commissioned in 2017-2018}

A new energy agreement in the Netherlands was implemented in 2013 that identified the need for additional wind farm projects to be developed to reach a total of 4,450 MW by 2023, with 1,000 MW being in place or under construction by 2015 (Loyens \& Loeff 2015). This includes the Gemini wind farm that was used as the representative site for the Task 26 Cost Model (Table 6). Gemini was fully commissioned in April 2017 and was not awarded under a competitive auction round. In contrast to future sites, the grid connection was constructed as part of the project but benefited from the Netherlands Stimulation of Sustainable Energy Production programme.

The Dutch government has since approved four further zones in 2016 that are split into two developments: Borssele I \& II (752 MW) and Borssele III \& IV (664-740 MW). Three further sites are expected to be consented by 2020 .

Table 6. Dutch Site Parameters

\begin{tabular}{|c|c|c|c|}
\hline Country & \multirow[b]{2}{*}{ Units } & \multirow{2}{*}{$\begin{array}{c}\text { Netherlands } \\
\text { Representative }\end{array}$} & \multirow{2}{*}{$\frac{\text { Netherlands }}{\text { Gemini }}$} \\
\hline Parameter & & & \\
\hline Mean wind speed & $\mathrm{m} / \mathrm{s}$ & 9.36 & 9.97 \\
\hline $\begin{array}{l}\text { Height for mean wind speed } \\
\text { measurement }\end{array}$ & $\mathrm{m}$ & 100 & 100 \\
\hline Average water depth & $\mathrm{m}$ & 33 & 32 \\
\hline Distance to construction port & $\mathrm{km}$ & 78 & 60 \\
\hline Distance to O\&M port & $\mathrm{km}$ & 78 & 90 (Eemshaven) \\
\hline Distance to cable landfall & $\mathrm{km}$ & 120 & 98 \\
\hline Export cable numbers & $\#$ & 2 & 2 \\
\hline Onshore cable length & $\mathrm{km}$ & 1 & 35 \\
\hline Number of offshore substations & & 2 & 2 \\
\hline Turbine expected & model & SWT-4.0-130 & SWT-4.0-130 \\
\hline Hub height expected & metres & 88.5 & 88.5 \\
\hline Turbine numbers & \# & 150 & 150 \\
\hline Capacity & MW & 600 & 600 \\
\hline Foundation expected & type & monopile & monopile \\
\hline Array cable rating expected & kV & 33 & 33 \\
\hline
\end{tabular}

\subsection{Representative Country Site}

\subsubsection{Assumed Location}

The sites highlighted in orange in Figure 9 are planned sites to be commissioned in 2020-2023 (Netherlands Enterprise Agency [RVO.nl] 2016). The representative site for commissioning in 2017-2018 is marked as " 4 ". 


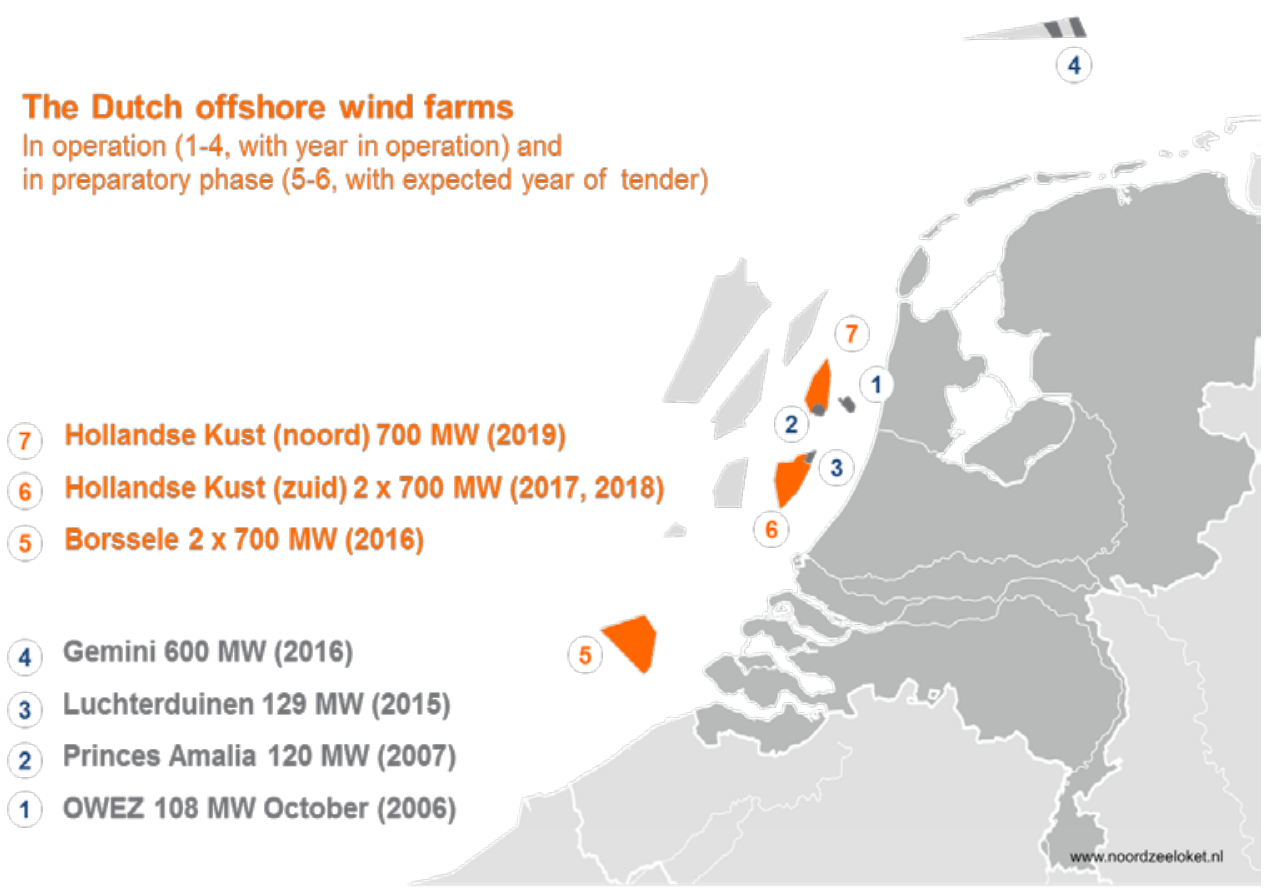

Figure 8. Dutch offshore wind farm sites

\subsubsection{Site Parameters}

Parameters for Dutch offshore wind farm sites include the following:

- Water depth. The representative site is at a water depth of $32 \mathrm{~m}$, in line with Gemini. This depth also reflects the next generation of sites that range from 16-38 m deep.

- Distance from shore. The representative site is situated approximately $78 \mathrm{~km}$ from port. This distance reflects Gemini; however, upcoming projects are all situated much closer, ranging between 20 and $22 \mathrm{~km}$ from shore.

- Mean wind speed. For all projects, there are consistently high mean recorded wind speeds — over $9.9 \mathrm{~m} / \mathrm{s}$. The capacity factor is estimated at $45.80 \%$.

\subsubsection{Technology Parameters}

Technology parameters for the Dutch offshore wind farm sites include the following:

- Turbine rating. Gemini was commissioned using 4-MW turbines, which is the size used in the representative case for 2017-2018. All future wind farms are expected to use turbines with a rating of $8 \mathrm{MW}$ and above.

- Foundation type. The representative site is modelled with monopiles. All sites expected in the next tender rounds are monopiles.

- Array cables. The representative site, consistent with Gemini, uses 33-kV cables; however, for future sites, $66 \mathrm{kV}$ are expected to become standard. 


\subsection{Finance and Tax Background}

\subsubsection{Debt Ratio}

The gearing ratio is estimated to be $70 \%$ for the representative site, based on an approximation of the ratio seen for the Gemini wind farm.

\subsubsection{Cost of Debt}

The cost of debt is assumed to be $4 \%$ - the same as the German market.

\subsubsection{Cost of Equity}

The cost of equity is assumed to be $13 \%$, similar to the German market with a slight uplift, based on less offshore wind experience than Germany.

\subsubsection{Tax}

The nominal corporate income tax rate in the Netherlands is $25 \%$ ( $20 \%$ for first $€ 200,000$ taxable income).

\subsection{Regulatory Regime}

\subsubsection{Revenue Support}

The Dutch Offshore Wind Programme operates using a CfD system under the Netherlands Simulation of Sustainable Energy Production tender and subsidy legislation (Netherlands Enterprise Agency undated). Successful companies with the lowest priced bid that meets all the specified requirements win a 15-year Netherlands Simulation of Sustainable Energy Production subsidy grant and 30-year permit to build, operate, and decommission the relevant wind farm.

\subsubsection{Development and Consent}

The Netherlands Offshore Wind Energy Act was adopted in 2015 (International Energy Agency 2016). Under the act, the government assumes responsibility from the offshore wind project investor regarding location, spatial planning arrangements, and environmental assessment of the proposed plants. Additionally, the act stipulates that the responsibility for offshore grid connection falls on the government, not on the project developer. This stipulation was implemented to simplify and accelerate the decision-making process for the realisation of offshore wind projects in an effort to enable the country to meet its 2020 renewable energy targets.

The Netherlands government takes on almost all of the risks associated with predevelopment work and regulates all conditions for building the wind farms. Permits and site studies are made publicly available to provide companies with a detailed understanding of the project they are bidding for in each tender round.

\subsubsection{Transmission}

The state TSO, TenneT, is responsible for building the required grid connections for the offshore wind farm.

\subsubsection{Regulatory Charges}

There are no additional regulatory charges imposed on wind farm operators in the Netherlands. 


\subsection{Country-Specific LCOE}

Figure 10 illustrates the impact of each of these categories on LCOE. The LCOE of the 2016 baseline is on the left, followed by the reduction associated with the updated costs to align the baseline with 2017 project LCOE. The Netherlands sees a small LCOE benefit in having a larger site capacity. However, the representative site conditions used to represent sites being commissioned in 2016-2017 are deeper water and farther from shore than the baseline site. It is worth noting that this may not be a trend that will continue, with recently approved sites being significantly closer to shore. The Dutch site with generic regulatory inputs LCOE is $€ 153 / \mathrm{MWh}$.

Financially, the Netherlands is a very attractive country to invest in offshore wind. Transmission costs are borne by grid operators and the Dutch consenting regime, which reduces risk to the developer. These items combined with a lower cost of financing and a lower tax rate brings the final LCOE to $€ 102 / \mathrm{MWh}(\$ 118 / \mathrm{MWh})$.

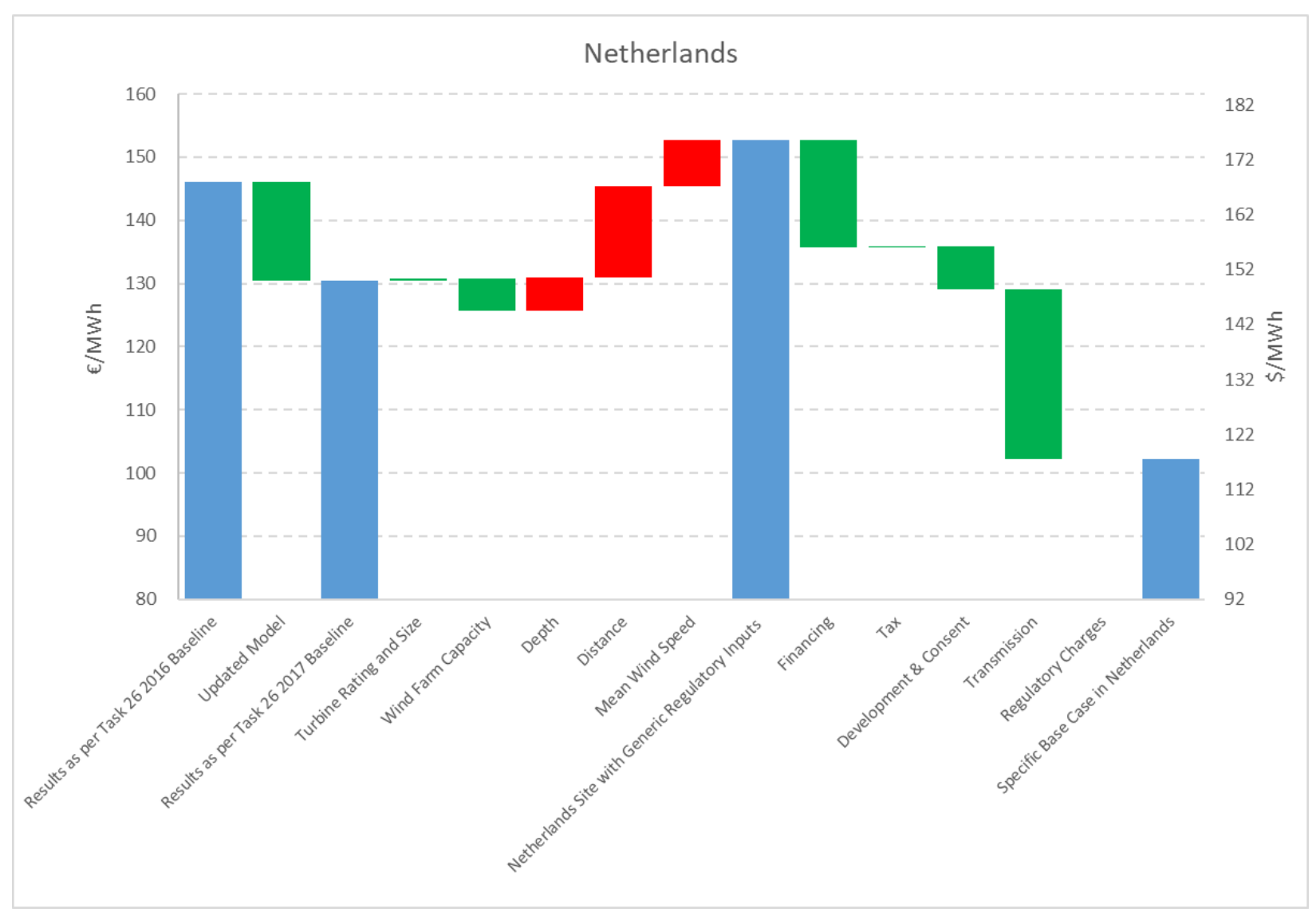

Figure 9. Waterfall chart of Dutch representative site 


\section{United Kingdom}

\subsection{Sites Being Commissioned in 2017-2018}

The sites being commissioned in 2017-2018 have been approved under a mix of support schemes, detailed in Section 5.4. In contrast with many other European regimes, developers in the United Kingdom must select a site, develop, and gain consent before submitting a bid into an auction round.

As an island, the United Kingdom has relatively greater coastline to develop offshore wind sites as well as an industry that is more spread across the country.

The representative site used for the Task 26 Cost Model has in general been compiled as a capacity-weighted average of the sites defined in Table 7.

Table 7. United Kingdom Site Parameters

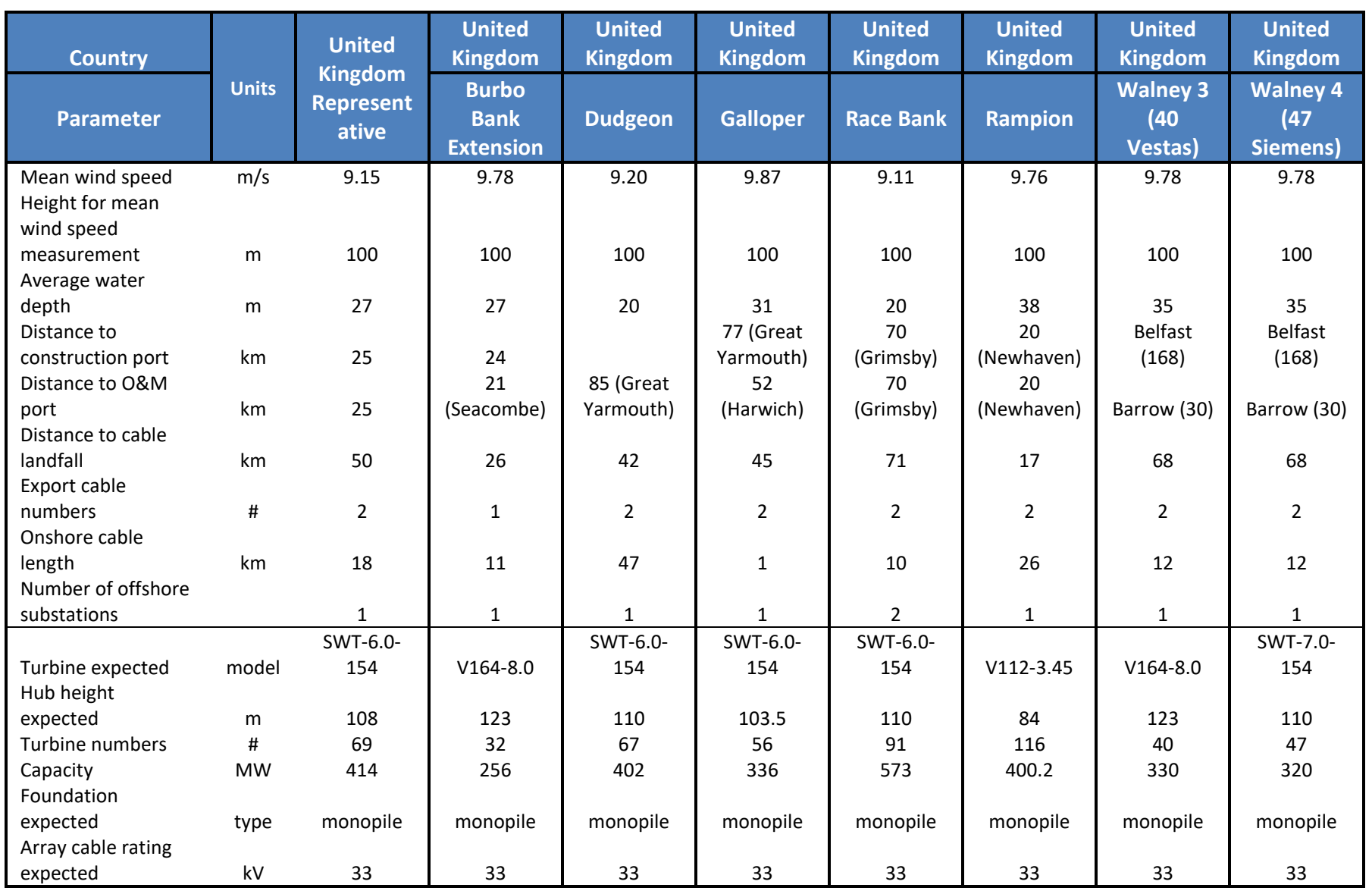

\subsection{Representative Country Site}

\subsubsection{Assumed Location}

Figure 11 shows relevant U.K. offshore wind sites considered in this study. The sites highlighted in green are being commissioned in 2017 and 2018 and are included in this study. The sites in purple have been awarded CfD contracts and are scheduled for commissioning in 2019-2021. 
The U.K. representative site has been modelled using the Dudgeon location. It is approximately $400 \mathrm{MW}$ and covers $55 \mathrm{~km}^{2}$ off the east coast of England where there will be a great deal of offshore wind development in upcoming years.

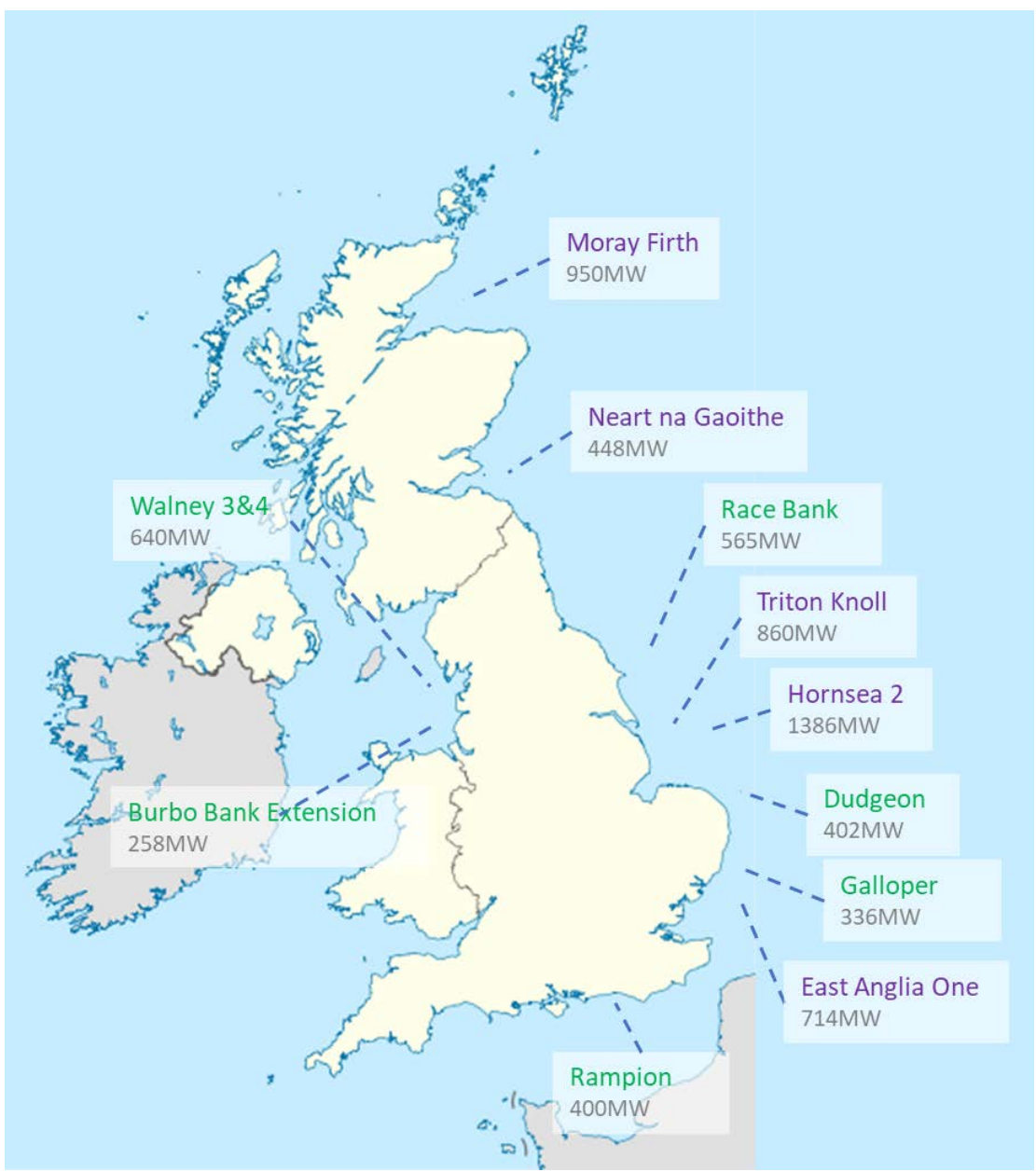

Figure 10. U.K. offshore wind sites

\subsubsection{Site Parameters}

The U.K. offshore wind industry is spread across a wide coastline both east and west of the country, with several hubs in development throughout. Parameters for offshore wind sites in the United Kingdom include the following:

- Water depth. The sites being commissioned in 2017-2018 have a water depth ranging from 8-38 $\mathrm{m}$. Waters to the east of the United Kingdom are shallower, on average, whereas waters that are north of Scotland and west of the Irish Sea are deeper.

- Distance from shore. The sites being commissioned in 2017-2018 are 11-38 km from the construction port. There is a lot of variation in the numbers as some turbines come from German and Danish ports directly to a site, though most construction and O\&M activity, as well as grid connection, is on the U.K. mainland.

- Mean wind speed. There are consistently high mean recorded wind speeds, over $9 \mathrm{~m} / \mathrm{s}$ for all projects. The capacity factor is estimated at $42.27 \%$. 


\subsubsection{Technology Parameters}

Technology parameters for the U.K. offshore wind sites include the following:

- Turbine rating. Projects currently in commissioning are using 6-8-MW turbines with the exception of Rampion, which will use 3.45-MW turbines. The representative site uses 6-MW turbines as the most popular turbine rating choice.

- Foundation type. All the sites modelled here are monopiles. As deeper water sites in harsher wave conditions get developed, more jacket foundations are expected to be used; for example, Beatrice (35-50 m water depth) and East Anglia One (30-41 m water depth).

- Array cables. As in other countries, all sites are using 33-kV cables; however, future sites (including East Anglia One) are expected to move to $66-\mathrm{kV}$ cables.

\subsection{Finance and Tax Background}

The 2016 Cost Reduction Monitoring Framework (CRMF) gathered evidence of cost reduction impact across the offshore wind value chain and included metrics on cost of finance (Offshore Wind Programme Board 2016). This evidence base has been used to inform the financial inputs for the representative U.K. site.

\subsubsection{Debt Ratio}

CRMF data showed that gearing in both construction and operational projects has increased in some cases to levels of $70 \%$ and above. Debt finance is also being brought in at an earlier stage, with project finance coming in at a final investment decision (FID) in some cases and this level of debt finance is expected to be sustainable. Gearing for the transmission element of projects has reached as high as $85 \%$ because of the shorter-term nature of lending (see Section 5.4.3 on U.K. transmission). Although gearing above $70 \%$ is not uncommon where debt financing is used, a debt ratio of $70 \%$ was applied for the representative U.K. site to reflect a wide range of financing, as some developers favour balance sheet or shareholder loan finance rather than external debt.

\subsubsection{Cost of Debt}

The CRMF study found evidence that the all-in cost of debt was typically in the range of 3.75\%$4 \%$ for the construction phase and $3.25 \%-3.75 \%$ for operations. However, depending on loan tenor and agreed conditions, rates are subject to change on later refinancing. Respondents agreed that the all-in cost of debt is influenced at least as much by developments in the wider economy (e.g., base rate movements and government bond yields) as by any factors specific to the offshore wind sector (e.g., increasing understanding of, and comfort with, the level of risk). For the United Kingdom, $4 \%$ was chosen to allow for the consensus that, with all-in debt rates at alltime lows, interest rates in the medium-to-long term are likely to rise.

\subsubsection{Cost of Equity}

The CRMF study forecasts that risk premiums have been decreasing and will continue to fall or remain the same. Sufficient capital is expected to be available to fund construction and operations, and investors and developers are becoming more comfortable with how risks should be priced, allocated, and managed. No respondents directly disclosed equity return expectations, and a $12.5 \%$ cost of equity has been used for the United Kingdom, which is expected to be commensurate with the level of gearing assumed. 


\subsubsection{Tax}

The current headline rate of U.K. corporation tax is 19\% (as of April 2017), which has been used as the tax rate for this comparative analysis. Tax depreciation (referred to as capital allowances in the United Kingdom) is given at $18 \%$ using the declining balance method.

\subsection{Regulatory Regime}

\subsubsection{Revenue Support}

The Renewable Obligation Certificate (ROC) regime has been phased out and replaced with the CfD scheme, which provides a guaranteed price for electricity generation for 15 years. Three of the projects being commissioned in 2017-2018 were awarded ROCs, which are worth roughly $£ 45 / \mathrm{MWh}$ (Office of Gas and Electricity Markets 2018). The remaining projects were awarded a strike price under the Final Investment Decision Enabling for Renewables (FIDER) process that was a lead into the current CfD regime. CfD auction rounds are increasingly competitive and driving strike prices down at each round. The first auction was held in 2015, resulting in the award of two sites: East Anglia One ( $£ 119.89$ [2012 real]), which is expected to be fully commissioned in 2020, and Neart na Gaoithe ${ }^{6}$ (£114.39 [2012 real]), expected to be fully commissioned in 2019. In 2017, an additional three sites were awarded strike prices: Triton Knoll at $£ 74.75 / \mathrm{MWh}(€ 86 / \mathrm{MWh}$ [2012 real]) commissioning in 2021, and both Moray Firth and Hornsea Two at £57.50/MWh (€64.10/MWh) (2012 real), commissioning in 2022. These are summarised in Table 8.

\footnotetext{
${ }^{6}$ The consent for Neart na Gaoithe and a number of other Scottish offshore wind farms has been the subject of legal review. The consents were reinstated in May 2017 in the Scottish courts and the project developer, Mainstream Renewables, expects to reach FID in 2018, with full commissioning by 2021. The Royal Society for the Protection of Birds raised an appeal to the Supreme Court, which was overturned in November 2017.
} 
Table 8. Summary of U.K. Projects Expected for Commissioning in 2017-2018

\begin{tabular}{|c|c|c|c|c|}
\hline $\begin{array}{l}\text { Project } \\
\text { Name }\end{array}$ & Tender Date & $\begin{array}{l}\text { Support } \\
\text { Scheme }\end{array}$ & Value $^{7}$ & $\begin{array}{l}\text { Tendered } \\
\text { Capacity }\end{array}$ \\
\hline $\begin{array}{l}\text { Burbo } \\
\text { Bank } \\
\text { Extension }\end{array}$ & April 2014 & FIDER & f150/MWh & $256 \mathrm{MW}$ \\
\hline Dudgeon & June 2014 & FIDER & f150/MWh & $402 \mathrm{MW}$ \\
\hline Galloper & May 2013 & ROC & $1.8 \mathrm{ROC} / \mathrm{MWh}$ & $336 \mathrm{MW}$ \\
\hline $\begin{array}{l}\text { Race } \\
\text { Bank }\end{array}$ & June 2014 & ROC & $1.8 \mathrm{ROC} / \mathrm{MWh}$ & $565 \mathrm{MW}$ \\
\hline Rampion & July 2014 & ROC & $1.8 \mathrm{ROC} / \mathrm{MWh}$ & $400 \mathrm{MW}$ \\
\hline Walney 3 & November 2014 & FIDER & f150/MWh & $320 \mathrm{MW}$ \\
\hline Walney 4 & November 2014 & FIDER & f150/MWh & $320 \mathrm{MW}$ \\
\hline $\begin{array}{l}\text { East } \\
\text { Anglia } \\
\text { One }\end{array}$ & June 2014 & $\mathrm{CfD}$ & f114.39/MWh & $714 \mathrm{MW}$ \\
\hline $\begin{array}{l}\text { Neart na } \\
\text { Gaoithe }\end{array}$ & June 2014 & CfD & f119.89/MWh & $448 \mathrm{MW}$ \\
\hline $\begin{array}{l}\text { Triton } \\
\text { Knoll }\end{array}$ & September 2017 & CfD & $f 74.75 / \mathrm{MWh}$ & $860 \mathrm{MW}$ \\
\hline $\begin{array}{l}\text { Moray } \\
\text { Firth }\end{array}$ & September 2017 & CfD & f57.50/MWh & $950 \mathrm{MW}$ \\
\hline $\begin{array}{l}\text { Hornsea } \\
\text { Two }\end{array}$ & September 2017 & CfD & f57.50/MWh & $\begin{array}{c}1,386 \\
\mathrm{MW}\end{array}$ \\
\hline
\end{tabular}

For projects commissioning beyond 2017, there is an additional expectation to provide a supply chain plan that outlines an intention to source at least $50 \%$ of contract value from within the U.K. supply chain (renewableUK 2017).

\subsubsection{Development and Consent}

In the United Kingdom, the developer is liable for all development costs and responsible for completing all surveys required to satisfy U.K. consenting conditions. This liability is a prerequisite to being granted a license and being eligible to apply for a $\mathrm{CfD}$. The development and consenting process can typically take up to 5 years, with costs of approximately tens of millions of pounds.

\subsubsection{Transmission}

In the United Kingdom, third-party offshore transmission operators (OFTOs) manage the transmission system. Developers may choose either the generator-build option-constructing the transmission assets themselves before transferring the assets to the third-party OFTO —or the OFTO-build option, in which the OFTO constructs the transmission assets. In all projects thus far, and due to the criticality of the transmission assets to the overall programme, developers

${ }^{7}$ All prices stated in 2012 real terms. 
have opted to follow the generator-build route. The transmission system is then competitively bid for purchase by OFTOs under tender rounds run by the U.K. market regulator, the Office of Gas and Electricity Markets, who also selects the winning bidder. The OFTO receives a revenue stream from National Grid, who in turn charges the wind farm owner an offshore transmission network use of system fee to recover the majority of the costs, with the balance of costs being socialised among all users across the wider transmission system.

\subsubsection{Regulatory Charges}

Offshore wind regulatory charges in the United Kingdom include:

- Onshore transmission network use of system. Location-based charge levied by National Grid on wind farm owners based on proximity to demand, currently ranging from roughly $£ 0$ to $£ 20$ per kilowatt per year

- Balancing services use of system. Charge levied on wind farm owners by the Office of Gas and Electricity Markets to recover the costs of balancing system supply and demand. The amount charged varies on a half-hourly basis, but the same tariff is charged to all grid users.

Offshore wind farm owners in the United Kingdom pay seabed leasing charges to the Crown Estate, fixed at c. $1 \%$ of gross wind farm revenues, and so vary in line with a project's power output (Ernst \& Young 2009).

\subsection{Country-Specific LCOE}

Figure 12 illustrates the impact of each of the previously mentioned categories on LCOE. The LCOE of the 2016 baseline is on the left, followed by the reduction associated with the updated costs to align the baseline with 2017 project LCOE. The U.K. representative site is quite similar to the baseline site, although lower wind speeds increase the levelised cost to $€ 138 / \mathrm{MWh}$ with generic regulatory inputs. The United Kingdom has a lower equity return expectation than the baseline $(12.5 \%$ vs. $15 \%)$ and a lower debt interest rate (4\% vs. $5 \%)$. Along with a more favourable capital allowance structure and a lower headline tax rate, this sums to a considerable reduction in nonproject costs. Additional country-specific factors covering transmission infrastructure charges and additional subsea leasing charges approximately offset each other, giving a final LCOE of $€ 115 / \mathrm{MWh}(\$ 132 / \mathrm{MWh})$. 


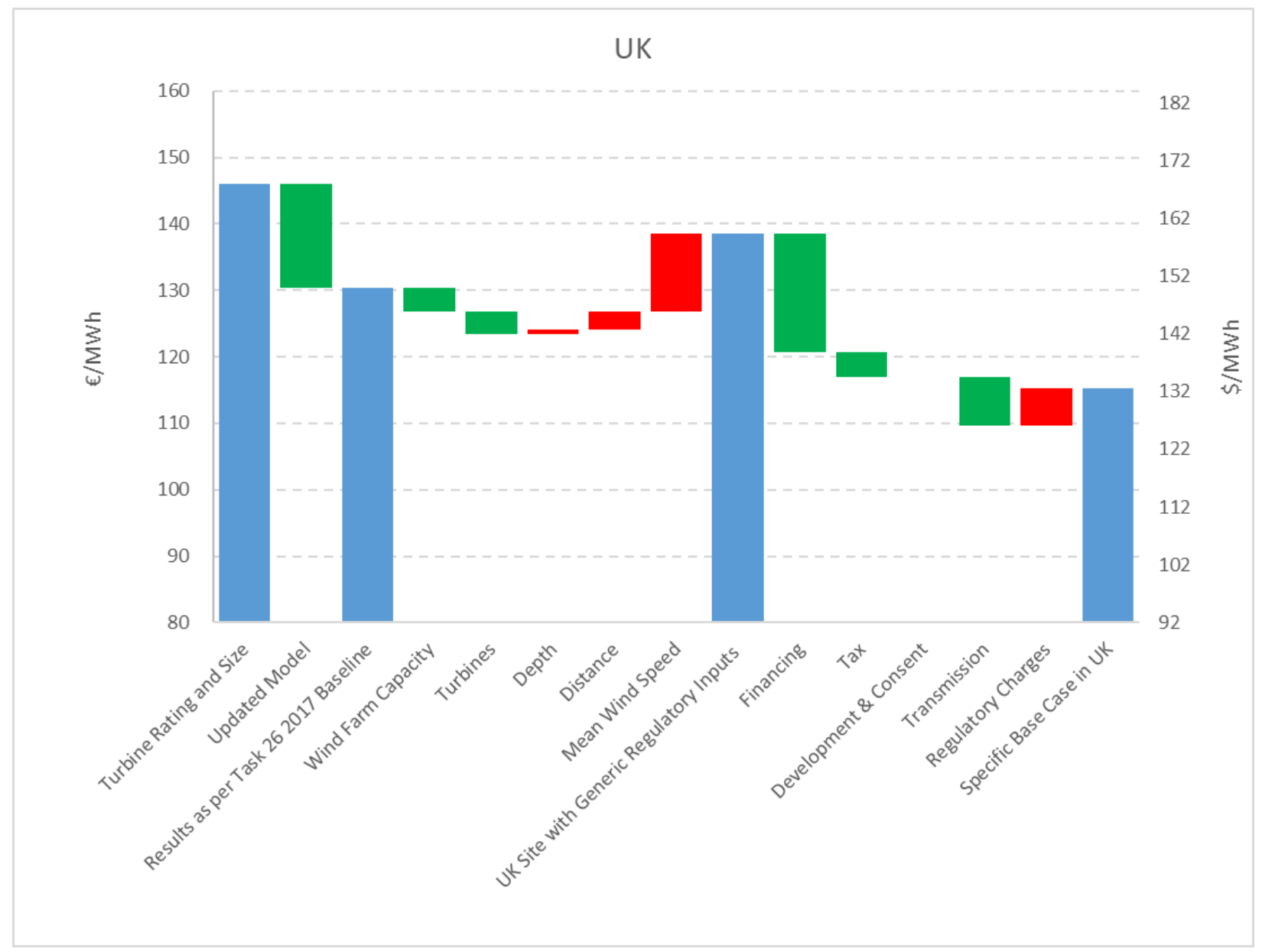

Figure 11. Waterfall chart of U.K. representative site

This report is available at no cost from the National Renewable Energy Laboratory (NREL) at www.nrel.gov/publications. 


\section{Belgium}

\subsection{Sites Being Commissioned in 2017-2018}

In 2017, Belgium had 877 MW of installed offshore wind capacity. The last new site to be commissioned was approved in 2015 and fully commissioned in 2017. Progress has since slowed down and only Norther, which is expected to be fully commissioned in 2019, has reached an FID since then (Table 9). Further sites expect to be developed, including Northwester 2, Mermaid, and Seastar, which were each awarded a strike price of $€ 79 / \mathrm{MWh}$ in 2017 , with construction expected by 2020 (offshore WIND.biz 2017).

Table 9. Belgian Site Parameters

\begin{tabular}{|c|c|c|c|c|c|}
\hline Country & & Belgium & Belgium & Belgium & Belgium \\
\hline Parameter & Units & & Nobelwind & Norther & Rentel \\
\hline $\begin{array}{l}\text { Mean wind speed } \\
\text { Height for mean wind speed } \\
\text { measurement } \\
\text { Average water depth } \\
\text { Distance to construction port } \\
\text { Distance to O\&M port } \\
\text { Distance to cable landfall } \\
\text { Export cable numbers } \\
\text { Onshore cable length } \\
\text { Number of offshore } \\
\text { substations }\end{array}$ & $\begin{array}{c}\mathrm{m} / \mathrm{s} \\
\text { metres } \\
\text { metres } \\
\mathrm{km} \\
\mathrm{km} \\
\mathrm{km} \\
\# \\
\mathrm{~km}\end{array}$ & $\begin{array}{c}10.20 \\
100 \\
29 \\
33 \\
33 \\
40 \\
1\end{array}$ & $\begin{array}{c}10.16 \\
100 \\
33 \\
46\end{array}$ & $\begin{array}{c}16 \\
103 \\
33 \text { (Ostend) } \\
23\end{array}$ & $\begin{array}{c}10.20 \\
\\
100 \\
22 \\
32 \\
40 \text { (Ostend) } \\
25 \\
2\end{array}$ \\
\hline Turbine expected & model & SWT 7.0-154 & V112-3.3 & V164-8.0 & SWT 7.0-154 \\
\hline Hub height expected & metres & 106 & 79 & & 106 \\
\hline Turbine numbers & $\#$ & 42 & 50 & 44 & 42 \\
\hline Capacity & MW & 309 & 165 & 369.6 & 309 \\
\hline Foundation expected & type & monopile & monopile & monopile & monopile \\
\hline Array cable rating expected & $\mathrm{kV}$ & 33 & 33 & 33 & 33 \\
\hline
\end{tabular}

\subsection{Representative Country Site}

\subsubsection{Assumed Location}

As Figure 13 shows, Belgian offshore wind farms are concentrated in a small area located close to the planned Borssele sites in the Dutch North Sea. 
The sites being commissioned in 2017-2019 are highlighted in Figure 13, either framed in blue, or in the case of Nobelwind, which is partially operating, shaded light blue, and Norther, which has not yet started construction, shaded in white.

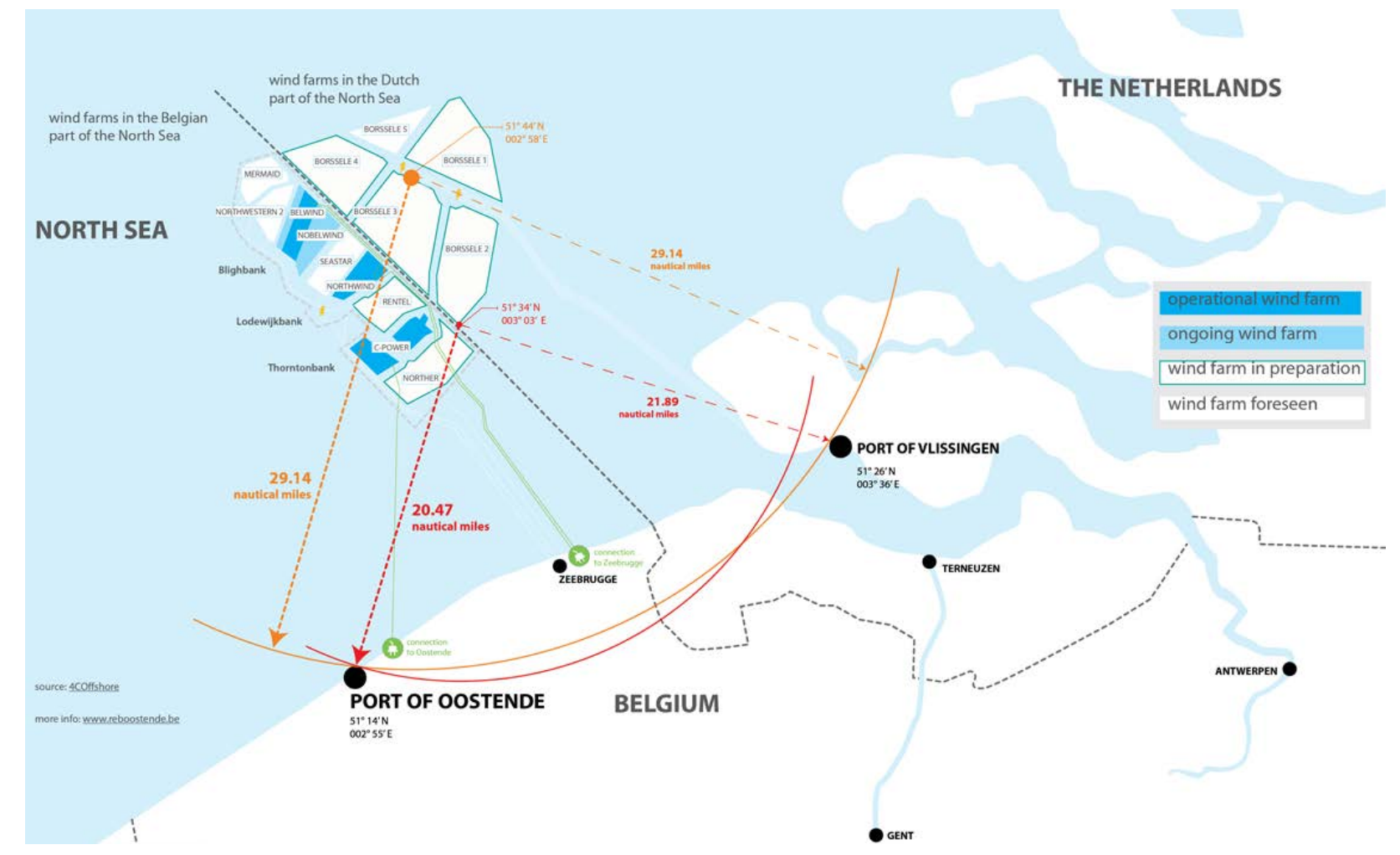

Figure 12. Belgian offshore wind sites. Image from the Renewable Energy Base Oostende

\subsubsection{Site Parameters}

Parameters for offshore wind sites in Belgium include the following:

- Water depth. The sites being commissioned in 2017-2019 have a water depth ranging from 13-34 m. The water depth at the representative site is $29 \mathrm{~m}$.

- Distance from shore. The sites being commissioned in 2017-2019 are 22-103 km from the construction port.

- Mean wind speed. At these sites, there are consistently high mean recorded wind speeds - over $10 \mathrm{~m} / \mathrm{s}$ for all projects. The capacity factor is estimated at $42.94 \%$.

\subsubsection{Technology Parameters}

Technology parameters for offshore wind sites in Belgium include the following:

- Turbine rating. The sites in commissioning have a range of turbines planned, from 3.3 MW on Nobelwind to $8 \mathrm{MW}$ for Norther. The representative case assumes 7-MW turbines in line with Rentel wind farm.

- Foundation type. In water depths similar to offshore Belgium, the use of monopiles is expected. 
- Array cables. The representative site, in line with all Belgian sites currently in commissioning, uses $33-\mathrm{kV}$ cables; however, for future sites, $66 \mathrm{kV}$ are expected to become standard.

\subsection{Finance and Tax Background}

Terms related to financing and taxes for Belgium offshore wind sites are as follows.

- Debt Ratio. The gearing ratio for the representative site is estimated to be $75 \%$, based on an approximation of the ratio seen for Rentel wind farm, with stated project costs of $€ 1.1 \mathrm{bn}$ (Dredging, Environmental \& Marine Engineering 2018)and debt finance of $€ 850 \mathrm{~m}$ (Loyens \& Loeff 2016).

- Cost of Debt. The cost of debt is assumed to be $4 \%$, the same as the German market, given similar risk profiles and the ability to access similar sources of funding.

- Cost of Equity. The cost of equity is assumed to be $13 \%$, similar to the German market with a slight uplift, reflecting a potential premium for the fact that the industry is less mature than in Germany.

\subsubsection{Tax}

Belgium has the highest standard corporate income tax of the European countries in this study at $33.99 \%$. Wind farms may be eligible for a one-off investment deduction of $13.5 \%$ on certain items of the acquisition value. Under Belgian tax law, depreciation of business assets is calculated on the basis of the acquisition cost over the useful life of the assets (KPMG International 2014).

\subsection{Regulatory Regime}

\subsubsection{Revenue Support}

A review of the offshore wind subsidy system took place in late 2013 and the previous Renewable Energy Certificates were replaced by a CfD system similar to many other countries in Europe. Operators receive this subsidy for every megawatt-hour produced at a guaranteed minimum price over 20 years. After the subsidy period is finished, a 10-year project life extension (without subsidy) is possible.

With such low strike prices being awarded in nearby waters in the Netherlands, developers in Belgium are under a lot of pressure to bring down costs. The two most recent projects in Belgium (Rentel and Nobelwind) were awarded revenues via Renewable Energy Certificates at $€ 95.25$ per MWh on top of wholesale electricity price for 20 years (offshoreWIND.biz 2016). The next three sites to be developed will only receive $€ 79.00$ per MWh (offshoreWIND.biz 2017).

\subsubsection{Development and Consent}

Developers in Belgium must obtain domain and environmental permits for the development zone and authorisation for construction and operation, issued by the Ministry of the Environment to carry out a certain activity under specified conditions and during a given period (European Commission Joint Research Centre 2015). 


\subsubsection{Transmission}

The privatised transmission grid operator Elia provides access to all wind farms in Belgium and is responsible for balancing electricity supply. The developer bears the costs of the grid connection to the onshore substation. However, these costs are partially subsidised by $33 \%$ of the investment, up to a maximum of $€ 25 \mathrm{~m}$. The subsidy is spread over 5 years (by providing $20 \%$ each year) and is covered by Elia.

Elia is currently constructing an offshore wind grid hub for North Sea projects including Rentel, Northwester 2, Mermaid, and Seastar (reNEWS 2017). An offshore substation $40 \mathrm{~km}$ from shore will connect to shore via three $22-\mathrm{kV}$ cables. Once the modular offshore grid is constructed, Elia will own and operate the offshore assets. As part of this investment, Elia will also acquire assets already built by Rentel.

\subsubsection{Regulatory Charges}

There are no additional regulatory charges imposed on wind farm operators in Belgium.

\subsection{Country-Specific LCOE}

Figure 14 illustrates the impact of each of these categories on LCOE. The LCOE of the 2016 baseline is on the left, followed by the reduction associated with the updated costs to align the baseline with 2017 project LCOE. Notably, the Belgian representative site capacity is lower than the baseline, which increases the LCOE as certain fixed costs, such as transmission, are levelized across a lower quantity of energy production. However, a higher turbine rating more than offsets this effect by providing cost savings elsewhere in the project. Site conditions (water depth and distance to shore) are similar to the baseline; however, Belgium has the lowest mean wind speed of the countries in this study, which yields a lower power output. The Belgian site with generic regulatory inputs LCOE is $€ 146 / \mathrm{MWh}$.

Belgium benefits from an attractive cost of financing before incorporating the local tax regime, which is the highest tax rate of the European countries modelled. This higher rate contributes to the final LCOE of $€ 139 / \mathrm{MWh}(\$ 160 / \mathrm{MWh})$. 


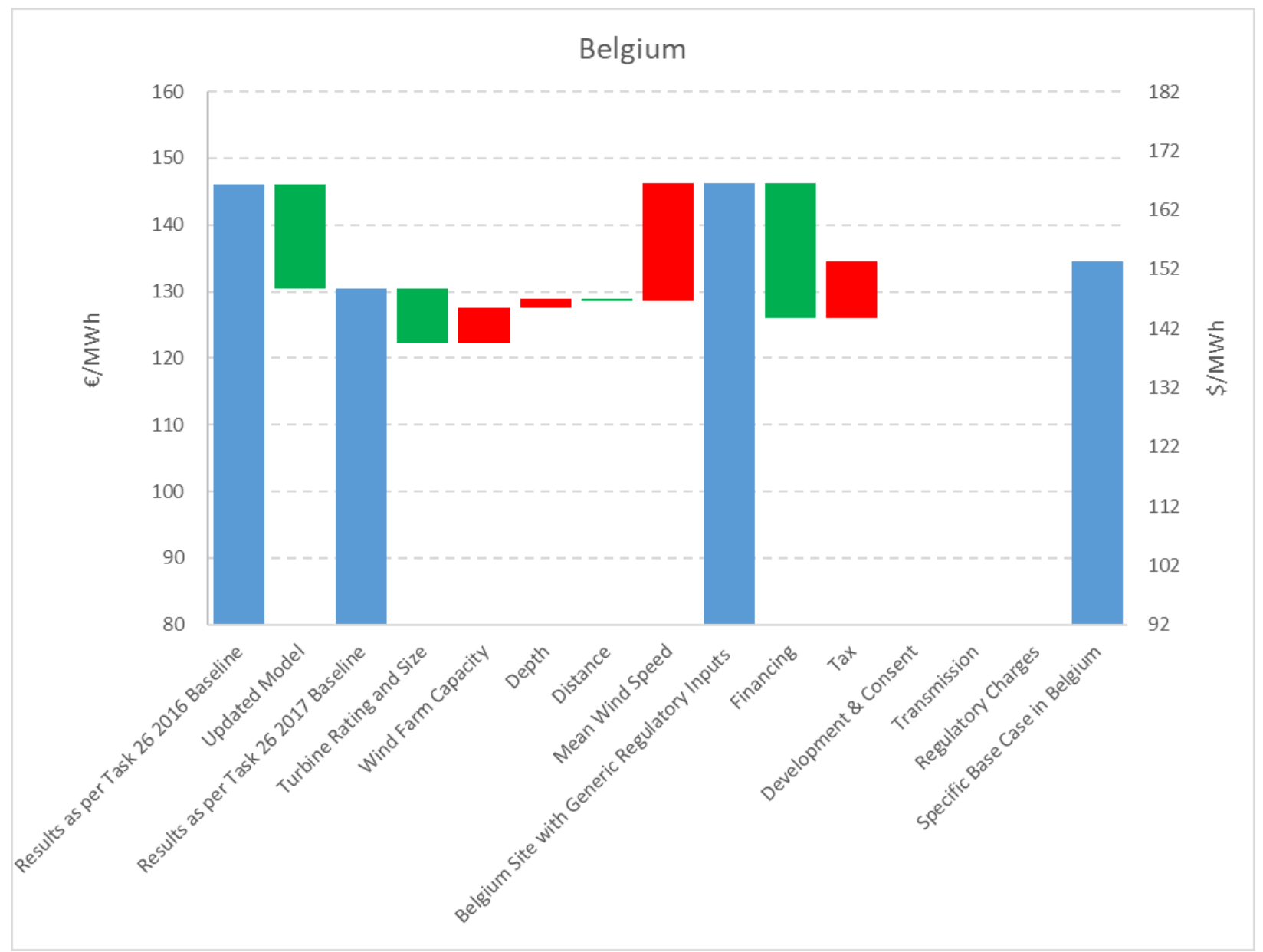

Figure 13. Waterfall chart of Belgian representative site

This report is available at no cost from the National Renewable Energy Laboratory (NREL) at www.nrel.gov/publications. 


\section{United States}

\subsection{Sites Being Commissioned in 2017-2018}

The United States is not expecting commissioning of a commercial-scale offshore wind plant in the 2017-2018 time frame and has only one commercial wind plant operating off the coast of Block Island, Rhode Island. However, there is a significant amount of activity in the U.S. offshore wind project pipeline going forward. Twelve commercial offshore wind projects have obtained site control ${ }^{8}$ by winning a competitive auction offer from the Bureau of Ocean Energy Management (BOEM). Five commercial offshore wind projects have unsolicited applications to BOEM and intend to participate in future competitive leasing activities. Four demonstration projects have obtained site control from federal or state authorities. Lastly, four unleased areas inside BOEM's wind energy areas (WEAs) are in planning to be leased. Additional information on these offshore wind projects can be found in the 2016 Offshore Wind Technologies Market Update (Musial et al. 2017) released by the U.S. Department of Energy.

\subsection{Representative Country Site}

The LCOE for the United States representative site assumes the site and technology parameters shown in Table 10. Notably, a fixed-bottom substructure technology vs. floating (i.e., jacket vs. semisubmersible) is assumed in the North Atlantic region of the United States. The representative site characteristics are derived from these columns and those technologies are likely to be implemented for offshore wind projects in the near future.

Table 10. U.S. Site Parameters

\begin{tabular}{|c|c|c|c|c|}
\hline \multicolumn{2}{|l|}{ Country } & \multirow{2}{*}{$\begin{array}{c}\text { U.S. } \\
\text { Representative } \\
\text { Site }\end{array}$} & \multirow{2}{*}{$\begin{array}{c}\text { North } \\
\text { Atlantic } \\
\text { Fixed Bottom }\end{array}$} & \multirow{2}{*}{$\begin{array}{l}\text { North } \\
\text { Atlantic } \\
\text { Floating }\end{array}$} \\
\hline Parameter & Units & & & \\
\hline Mean wind speed & $\mathrm{m} / \mathrm{s}$ & 8.99 & 8.99 & 8.99 \\
\hline $\begin{array}{l}\text { Height for mean wind speed } \\
\text { measurement }\end{array}$ & metres & 100 & 100 & 100 \\
\hline Average water depth & metres & 30 & 30 & 100 \\
\hline Distance to construction port & $\mathrm{km}$ & 30 & 30 & 60 \\
\hline Distance to O\&M port & $\mathrm{km}$ & 30 & 30 & 60 \\
\hline Distance to cable landfall & $\mathrm{km}$ & 30 & 30 & 60 \\
\hline Export cable numbers & $\#$ & 2 & 2 & 2 \\
\hline Onshore cable length & $\mathrm{km}$ & 10 & 10 & 10 \\
\hline Number of offshore substations & & 1 & 1 & 1 \\
\hline Turbine expected & model & Haliade - 150 & Haliade - 150 & Haliade - 150 \\
\hline Hub height expected & metres & 100 & 100 & 100 \\
\hline Turbine numbers & \# & 76 & 100 & 100 \\
\hline Capacity & MW & 600 & 600 & 600 \\
\hline Foundation expected & type & jacket & jacket & semisubmersible \\
\hline Array cable rating expected & $\mathrm{kV}$ & 33 & 33 & 33 \\
\hline
\end{tabular}

\footnotetext{
${ }^{8}$ Site control means that a developer has acquired an exclusive offshore wind lease from the Bureau of Ocean Energy Management or a state entity and now has the ability to conduct site-specific tests and initiate construction when all regulatory requirements have been satisfied.
} 


\subsubsection{Assumed Location}

The United States has a diverse set of offshore site characteristics and meteorological ocean conditions. These various characteristics and conditions are spread across 25 offshore WEAs, Call Areas, ${ }^{9}$ and demonstration site ${ }^{10}$ that make up the U.S. offshore wind pipeline.

As shown in Figure 15, a majority of the offshore wind project pipeline activity is taking place on the Atlantic Coast, more specifically the North Atlantic region of the United States, with WEAs that are in shallower water and relatively close to shore. Hence, the representative U.S. offshore wind farm in 2016 is assumed to lie within this offshore region of the country (Musial et al. 2017).
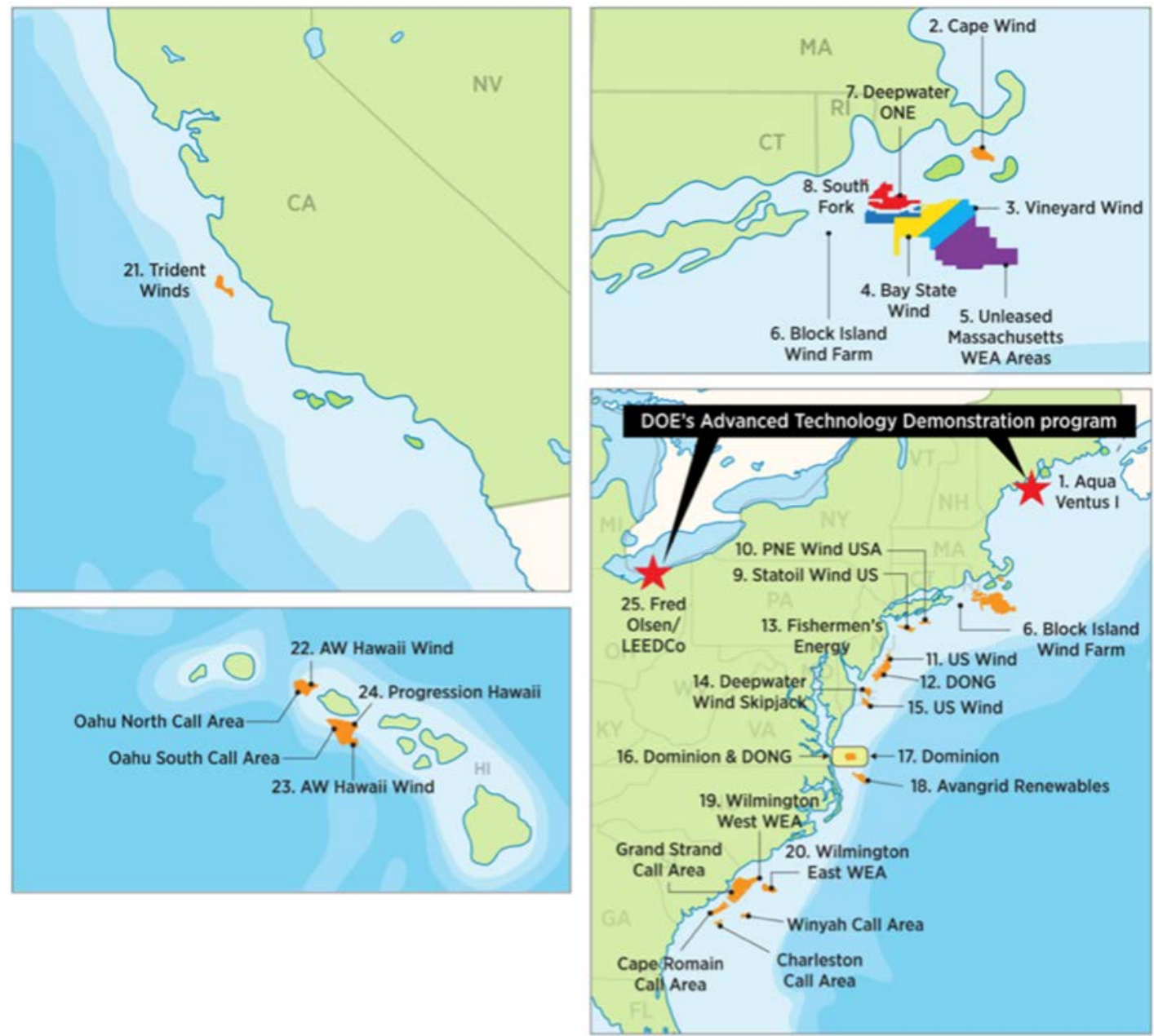

Figure 14. U.S. offshore wind sites

(Source: NREL)

\footnotetext{
${ }^{9}$ Call Areas are identified to determine commercial interest in potential future offshore wind lease sites and to engage with local stakeholders.

${ }^{10}$ Demonstration sites are part of the U.S. Department of Energy’s Advanced Technology Demonstration Projects Program.
} 


\subsection{Site Parameters}

- Water depth. The water depth for the WEAs in the North Atlantic region of the United States generally ranges between 20 and $40 \mathrm{~m}$. The water depth for the U.S. site is slightly deeper than the Task 26 baseline site ( $30 \mathrm{~m}$ vs. $25 \mathrm{~m}$ ). The Task 26 baseline site uses a monopile substructure, whereas the U.S. site uses a jacket substructure. The cost difference between these structures and the associated cost for installation increases LCOE. Although monopile substructures are still viable in water depths of $30 \mathrm{~m}$, the U.S. site assumes a jacket substructure for various reasons: 1) to avoid potential noise concerns for installation of monopiles for marine wildlife, 2) the utilisation of existing U.S. manufacturing facilities, installation vessels, and an experienced labour force from the oil and gas industry, 3) metocean limits, such as breaking waves introduced by hurricanes, and 4) consideration of diverse soil conditions.

- Distance from shore. The U.S. representative site is assumed to be $30 \mathrm{~km}$ from shore. For analysis purposes, this distance is equivalent to the distance of the construction port and O\&M port. Near-term offshore projects closer to shore are expected to be developed first; however, as the distance from shore increases, the U.S. Outer Continental Shelf drops off and water depth increases, as a result, floating offshore wind foundations offer a long-term solution for the deeper sites further from shore.

- Mean wind speed. The mean wind speed of $8.99 \mathrm{~m} / \mathrm{s}$ at a $100-\mathrm{m}$ hub height is estimated by the Danish Technical University (DTU) for the North Atlantic region of the United States.

\subsubsection{Technology Parameters}

Based on the site parameters in the U.S. North Atlantic region, a set of wind farm technology assumptions are derived. The high-level U.S. representative wind farm technology parameters are shown in Table 10. The specific technology parameters for the U.S. offshore wind sites include the following:

- Turbine rating. At this time, the United States has one commissioned offshore wind project, the Block Island Wind Farm, off the coast of Block Island, Rhode Island. The turbines installed at this project are GE Haliade 150-6 MW offshore wind turbines. This turbine platform is selected to be representative of near-term U.S. offshore projects and the representative site in this report.

- Foundation type. The turbine foundation type selected for the North Atlantic representative site is a fixed-bottom, four-legged jacket foundation. This foundation technology supports the 6-MW offshore turbines at the Block Island Wind Farm. In general, the United States is more equipped for manufacturing jacket-type offshore foundations stemming from the existing oil and gas industry. The utilisation of monopile foundations in the North Atlantic is also feasible; however, these foundations are most likely to be manufactured in Europe and transported to the United States for installation. Additional restriction noise mitigation for marine wildlife may also present a challenge for monopile technology in the United States.

- Array cables. The 33-kV array cable selection for the representative U.S. offshore project is based on offshore wind projects in Europe for projects with similar site characteristics as the U.S. representative site. 


\subsection{Finance and Tax Background}

The finance (i.e., debt ratio, cost of debt, and cost of equity) and tax assumptions for the United States' offshore wind representative project are informed by financial analysis conducted in the 2015 Cost of Wind Energy Review (Mone et al. 2017). Notably, the United States offshore wind finance environment remains dynamic and somewhat uncertain with limited empirical project data to draw upon. The specific values discussed below as well as potential future financing structures continue to be a focus of ongoing research and analysis.

\subsubsection{Debt Ratio}

Offshore wind projects in Europe are structured by either a balance sheet or project financed. It is assumed the balance sheet projects have a $50 \%$ debt ratio and project-financed projects have a $60 \%$ debt ratio. These two project financial structures were weighted under the assumption that $55 \%$ of the 2015 offshore wind installed capacity utilized balance sheet financing and about $45 \%$ of the installed capacity utilised project-financed structures. The resulting 55\% debt ratio from this analysis is assumed for the representative U.S. offshore wind project. However, recent studies show higher debt ratios may be experienced for offshore wind in the United States (Green Giraffe 2018).

\subsubsection{Cost of Debt}

The cost of debt for the representative U.S. project uses the same methodology as was applied to determine the debt ratio. The weighted average of the two different financing structures (i.e., balance sheet and project finance) is $6.75 \%$.

\subsubsection{Cost of Equity}

As with the debt ratio and cost of debt calculation, the average cost of equity weighted across a number of projects results in $12.1 \%$ and is used as for the U.S. representative site.

\subsubsection{Tax}

The $40 \%$ tax rate for the representative U.S. project is a composite rate of state and federal taxes. This rate is calculated from a blend of the highest marginal corporate tax rate of $35 \%$ and an approximate typical state corporate tax rate. Because state taxes are deductible expenses on federal tax returns, the blended rate is represented as $35 \%+7.7 \% \times(100 \%-35 \%)=40 \%{ }^{11}$

This higher tax rate is mostly offset by the more favourable Modified Accelerated Cost Recover System tax depreciation system used in the United States. Despite this system, the higher composite tax rate in the United States results in an increase in LCOE compared to the Task 26 baseline.

\subsection{Regulatory Regime}

The United States has a variety of state and federal offshore wind policy types, including market scale and visibility, offtake policies, incentive mechanisms, regulatory support, supply chain

\footnotetext{
${ }^{11}$ The U.S. tax reform bill passed and signed in to law in December of 2017 (Tax Cuts and Jobs Act, H.R. 1) lowers the Corporate Tax Rate from 35\% to $21 \%$; however, the $35 \%$ corporate tax rate is used in this report since final investment decisions for projects commission in 2017-2018 timeframe would have been made prior to the tax reform.
} 
development, and innovation support. More information on each of these offshore wind policy types can be found in the 2016 Offshore Wind Technologies Market Report (Musial et al. 2017).

\subsubsection{Revenue Support}

As stated in the 2016 Offshore Wind Technologies Market Report (Musial et al. 2017), the incentive mechanism in the United States for offshore wind is known as the production tax credit. Its intention is to catalyse the growth of nascent industries or markets until they become self-sustaining. The U.S. Internal Revenue Service's production tax credit is an inflationadjusted, per-kilowatt-hour tax credit awarded for renewable electricity generation. Projects that commence construction after January 1, 2017, will be awarded $€ 16.00 / \mathrm{MWh}(\$ 18.40 / \mathrm{MWh})$ during the first 10 years of operation. The Internal Revenue Service's guidance increases developers' eligibility to receive the production tax credit for 4 years if they start physical construction or spend $5 \%$ of the project's total costs. The credit decreases by $20 \%$ each year before expiring in 2020 .

Another incentive mechanism is the investment tax credit. The Internal Revenue Service's investment tax credit provides a $30 \%$ tax credit on a renewable energy project's capital costs. For wind projects larger than $100 \mathrm{~kW}$, the investment tax credit decreases in value by $6 \%$ annually and expires on December 31, 2020. The Internal Revenue Service also has additional guidance on what constitutes construction activities for the investment tax credit.

\subsubsection{Development and Consent}

In the United States, the developer is liable for all development costs and responsible for completing all surveys required to satisfy state and federal requirements. BOEM has implemented an Outer Continental Shelf Renewable Energy Program and publishes documents containing rules that apply to offshore wind project development. These documents include rules on timing requirements for submitting site assessment plans, general activities plans, and environmental assessment plans (Bureau of Ocean Energy Management web page).

\subsubsection{Transmission}

Unlike the offshore wind projects being developed in most of mainland Europe, the establishment of transmission costs for offshore wind in the United States is the responsibility of the developer. The developer is responsible for constructing and operating all offshore transmission assets, often including onshore reinforcements (i.e., onshore substation and cable routing [IEA-Renewable Energy Technology Deployment 2017]). Grid connection in the United States is not yet determined for large-scale commercial projects.

\subsubsection{Regulatory Charges}

Both state and federal regulation charges and the transmission charges/rights are still in flux as the offshore wind industry in the United States is still growing. Currently, there are no transmission charges in place for TSOs or transmission asset owners for rights to transport power. Charges such as this may be introduced as the wind industry continues to mature and are expected to vary based on what region of the country the energy is being produced in. However, BOEM has a regulation in place that requires a WEA lease owner to make payments on the submerged land lease once the wind project is commissioned and generating energy. This recurring payment is calculated based on a percentage of net annual energy production at the wholesale market price (which varies widely by region). 


\subsubsection{Country-Specific LCOE}

Figure 16 illustrates the impact of each of these categories on LCOE. The LCOE of the 2016 baseline is on the left followed by the reduction associated with the updated costs to align the baseline with 2017 project LCOE. Economies of scale are seen through a higher site capacity of $456 \mathrm{MW}$ and use of 6-MW turbines that require lower balance-of-plant costs per installed megawatt. The 76-turbine site maximises the capacity that can be carried by a single $220-\mathrm{kV}$ export cable. Gross capacity factor is lower as a result of lower mean wind speed and losses introduced by wakes are higher, resulting in a lower net capacity factor than the Task 26 baseline. The increased water depth at the U.S. representative site in combination with the change of fixed-bottom substructure type (i.e., monopile to jacket) negatively impacts the LCOE, thereby requiring more expensive installation vessels capable of operating in deeper waters and more installation time out at sea for installing a jacket substructure. The U.S. site LCOE with generic regulatory inputs is $€ 148 / \mathrm{MWh}(\$ 171 / \mathrm{MWh})$.

The U.S. financial structure tends to increase the financial portion of LCOE. The lower cost of equity is mostly offset by reduced levels of gearing. The U.S. uses a blended state and federal tax rate estimate that comes out to be approximately $40 \%$, higher than the baseline site or any other countries in the study. The final LCOE is $€ 151 / \mathrm{MWh}(\$ 174 / \mathrm{MWh})$.

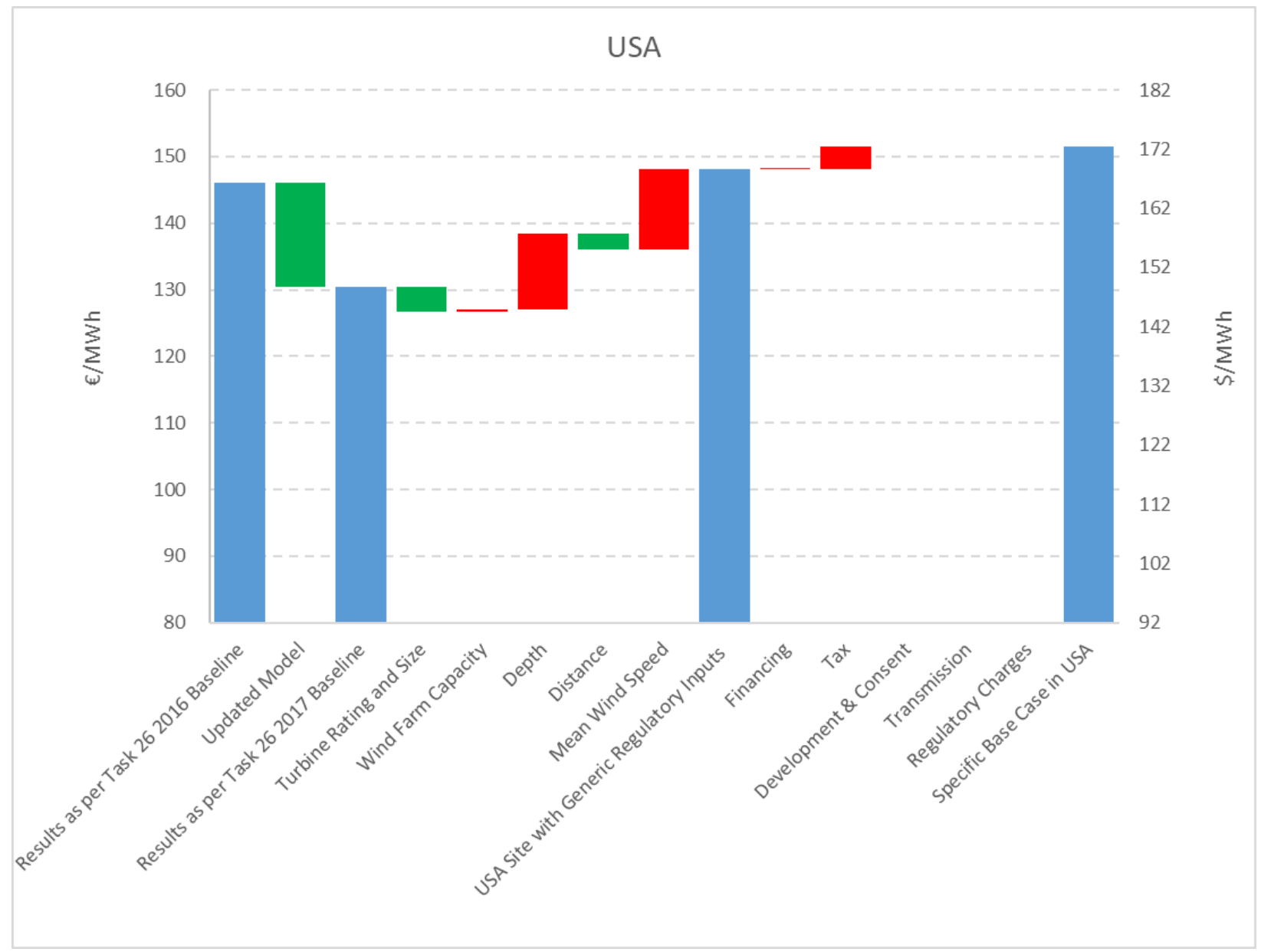

Figure 15. Waterfall chart of U.S. representative site 


\section{Japan}

\subsection{Sites Being Commissioned in 2017-2018}

Japan is not currently expecting commissioning of a commercial-scale offshore wind power plant in the 2017-2018 time frame. However, the Japanese government has invested significantly in the research and development of offshore wind energy. Four national demonstration projects have been completed, as shown in Figure 17. Two are fixed bottom (NEDO 2013a, 2013b) and the other two use floating substructures (Fukushima Offshore Wind Consortium web page; GOTO FOWT web page). Geographical and meteorological ocean conditions vary between these sites. Some fixed-bottom commercial offshore wind farms are under planning, all located near shore with a shallow water depth. The number of turbines is planned at 10-40, though Japan aims for larger wind farms in the future. Table 11 gives a breakdown of the parameters used for the Japanese representative fixed-bottom site.

Table 11. Japanese Site Parameters

\begin{tabular}{|l|c|c|}
\hline \multicolumn{1}{|c|}{ Country } & & \multirow{2}{*}{ Japan Representative } \\
\hline \multicolumn{1}{|c|}{ Parameter } & Units & \\
\hline Mean wind speed & $\mathrm{m} / \mathrm{s}$ & 8.37 \\
Height for mean wind speed measurement & $\mathrm{m}$ & 90 \\
Average water depth & $\mathrm{m}$ & 11.9 \\
Distance to construction port & $\mathrm{km}$ & 70 \\
Distance to O\&M port & $\mathrm{km}$ & 3 \\
Distance to cable landfall & $\mathrm{km}$ & 3 \\
Export cable numbers & $\#$ & 4 \\
Onshore cable length & $\mathrm{km}$ & - \\
Number of offshore substations & & - \\
\hline Turbine expected & model & generic \\
Hub height expected & $\mathrm{m}$ & 127 \\
Turbine numbers & $\#$ & 14 \\
Capacity & $\mathrm{MW}$ & 5.2 \\
Foundation expected & type & monopile \\
Array cable rating expected & $\mathrm{kV}$ & 33 \\
\hline
\end{tabular}

\subsection{Representative Country Site}

\subsubsection{Assumed Location}

As one of the most up-and-coming wind farm locations, Choshi is selected as the Japan representative site. In Choshi, a 2.4-MW wind turbine has been operated as a national demonstration project since 2013 (NEDO 2013a). 


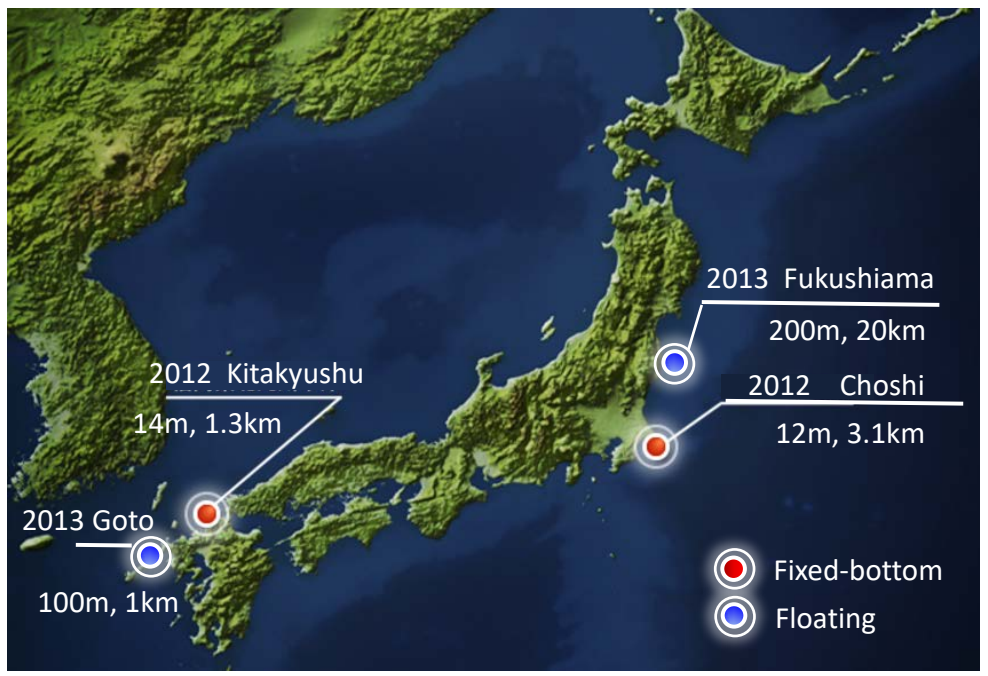

Figure 16. Japan offshore wind farm sites

\subsubsection{Site Parameters}

Parameters for the Japan offshore wind farm sites include the following:

- Water depth. Choshi is located at a 11.9-m water depth. All commercial projects proposed now are located at a water depth around $15 \mathrm{~m}$ to $30 \mathrm{~m}$. But it is worth noting that the vast majority of offshore wind energy potential in Japan is located at a water depth of more than $80 \mathrm{~m}$ and Japan has a keen interest in developing floating offshore wind farms.

- Distance from shore. Choshi is located $3.4 \mathrm{~km}$ from shore. All commercial projects proposed now are located at a distance of less than $10 \mathrm{~km}$.

- Mean wind speed. The mean wind speed of $8.37 \mathrm{~m} / \mathrm{s}$ at a $100-\mathrm{m}$ hub height is estimated by DTU for the site. NEDO has provided an offshore wind resource map in Japan, ${ }^{12}$ where the annual average wind speed surrounding Japan is available. The north part of Japan has a higher wind speed (around $9 \mathrm{~m} / \mathrm{s}$ ) than the Choshi site, which is also a promising area for offshore wind energy.

\subsubsection{Technology Parameters}

Technology parameters for the Japan offshore wind farm sites include the following:

- Turbine rating. For the representative site, 5.4-MW wind turbines are assumed. Currently, all turbines are planned between $4 \mathrm{MW}$ and $5 \mathrm{MW}$.

- Foundation type. As all commercial projects proposed now use a monopile foundation, this is also assumed in the representative site as appropriate for the given water depth.

- Array cables. For the representative site, 33-kV array cables are assumed.

\footnotetext{
${ }^{12}$ http://app10.infoc.nedo.go.jp/Nedo_Webgis/index.html
} 


\subsection{Finance and Tax Background}

\subsubsection{Debt Ratio}

As there are no commercial offshore wind farms in Japan, the debt ratio has high uncertainty. Therefore, the baseline value of $70 \%$ is used for the Japan representative site. In general, developers expect offshore wind energy to have higher risk than onshore wind since development is in the initial phase.

\subsubsection{Cost of Debt}

In Japan, the interest rate on debt is estimated as 3\% for infrastructure projects.

\subsubsection{Cost of Equity}

As for the cost of equity, the baseline value of $15 \%$ is used as the Japan representative site.

\subsubsection{Tax}

The corporate tax rate for Japan is $29.74 \%$ and the capital allowance rate is $11.8 \%$.

\subsection{Regulatory Regime}

The Ministry of Economy, Trade and Industry published the Long-term Energy Supply and Demand Outlook in 2015. In this document, the government set a target of $1.7 \%$ share of onshore and offshore wind energy in total power generation.

\subsubsection{Revenue Support}

Wind farms built in Japan are subject to a feed-in-tariff support scheme and the initial tariff will cover the whole project period. In 2018, the tariff is 36,000 Japanese yen/MWh (Agency for Natural Resources and Energy web page) (€270/MWh) for offshore wind energy.

\subsubsection{Development and Consent}

In Japan, the developer is liable for all development costs and responsible for completing all surveys and procedures required to satisfy government requirements, such as an Environmental Impact Assessment, Construction Plan Registration statement based on the Electricity Business Act, and Water Occupied Procedure based on the Port and Harbour Act. Recently, the government has tried to shorten the Environmental Impact Assessment process and to prepare a comprehensive guideline for the approval of the construction plan and water occupied procedure.

\subsubsection{Transmission}

Transmission costs in Japan are the responsibility of the developer. In Japan, the transmission lines are owned by the electricity company. The developer should negotiate and pay some cost to the electricity company for grid connection.

\subsubsection{Regulatory Charges}

There are no additional regulatory charges imposed on wind farm operators in Japan.

\subsection{Country-Specific LCOE}

Figure 18 illustrates the impact of each of these categories on LCOE. The LCOE of the 2016 baseline is on the left followed by the reduction associated with the updated costs to align the baseline with 2017 project LCOE. 
The wind farm capacity for the Japan site is $72.8 \mathrm{MW}$, which is much smaller than baseline of $456 \mathrm{MW}$, because Japan's commercial offshore wind farm development is in the initial phase. This smaller capacity results in a large increase in CAPEX and OPEX per megawatt due to increased fixed costs for transmission and vessel mobilisation. Gross capacity factor is lower as a result of lower mean wind speed. Considering energy production of the Japan offshore project, these effects result in a large negative impact on LCOE for wind farm capacity and turbines when compared with the baseline.

The water depth for Japan is shallower than the baseline site (12 m vs. $25 \mathrm{~m})$, resulting in a slightly positive impact on LCOE. Japan's site is also much closer to port and cable landfall than the baseline ( $2 \mathrm{~km}$ vs. $40 \mathrm{~km}$ ), which has an additional positive impact on LCOE. The Japan site LCOE with generic regulatory inputs is $€ 167 / \mathrm{MWh}(\$ 145 / \mathrm{MWh})$.

Financial structure is very uncertain in Japan and so the baseline value is used for debt ratio and cost of equity. Japan uses $30 \%$ tax, which results in a slight increase in LCOE. The final LCOE is $€ 158 / \mathrm{MWh}(\$ 137 / \mathrm{MWh})$.

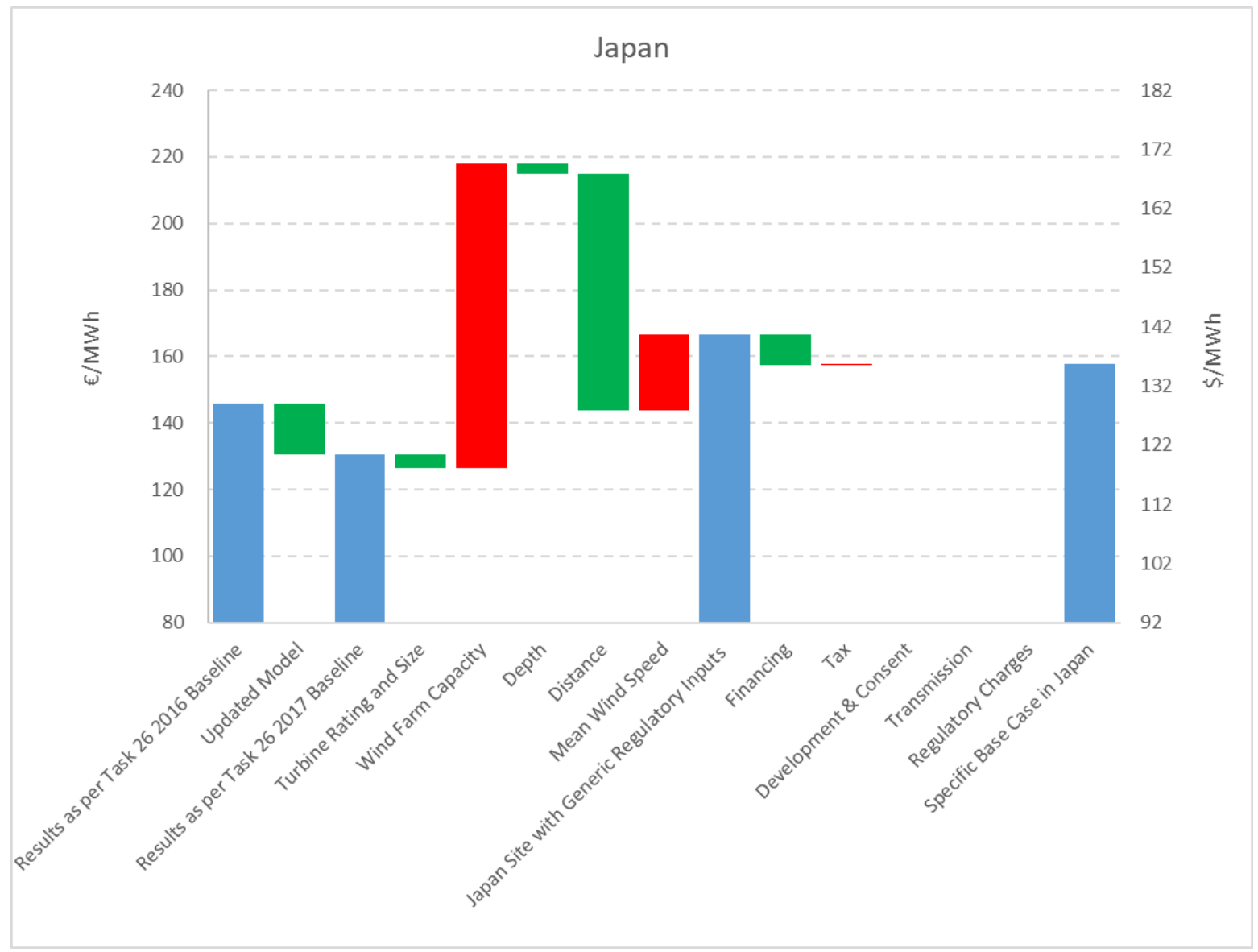

Figure 17. Waterfall chart of Japan representative site 


\section{Comparison Overview}

There is variation in the basis for the representative sites for the study. Countries with ongoing projects in construction can draw on the experiences of these sites but countries with no existing market have made technological assumptions based on site conditions and economic assumptions based on wind industries in similar markets (e.g., Japan). Figure 19 gives the relative LCOE of each country as individual parameters are changed from the baseline site to the country-specific data. The range of LCOE varies significantly when all country-specific aspects are considered. The spread widens particularly at the point that local legislation is accounted for, where socialised development and transmission cost in Denmark, Germany, and the Netherlands reduce LCOE by a margin. Japan stands out for its jump in cost when the representative site capacity is reduced from $400 \mathrm{MW}$ to $73 \mathrm{MW}$. This capacity reduces again when the small distance to shore is included, for which installing four lower-capacity export cables direct to shore makes financial sense.

These parameters are discussed further in the following sections.

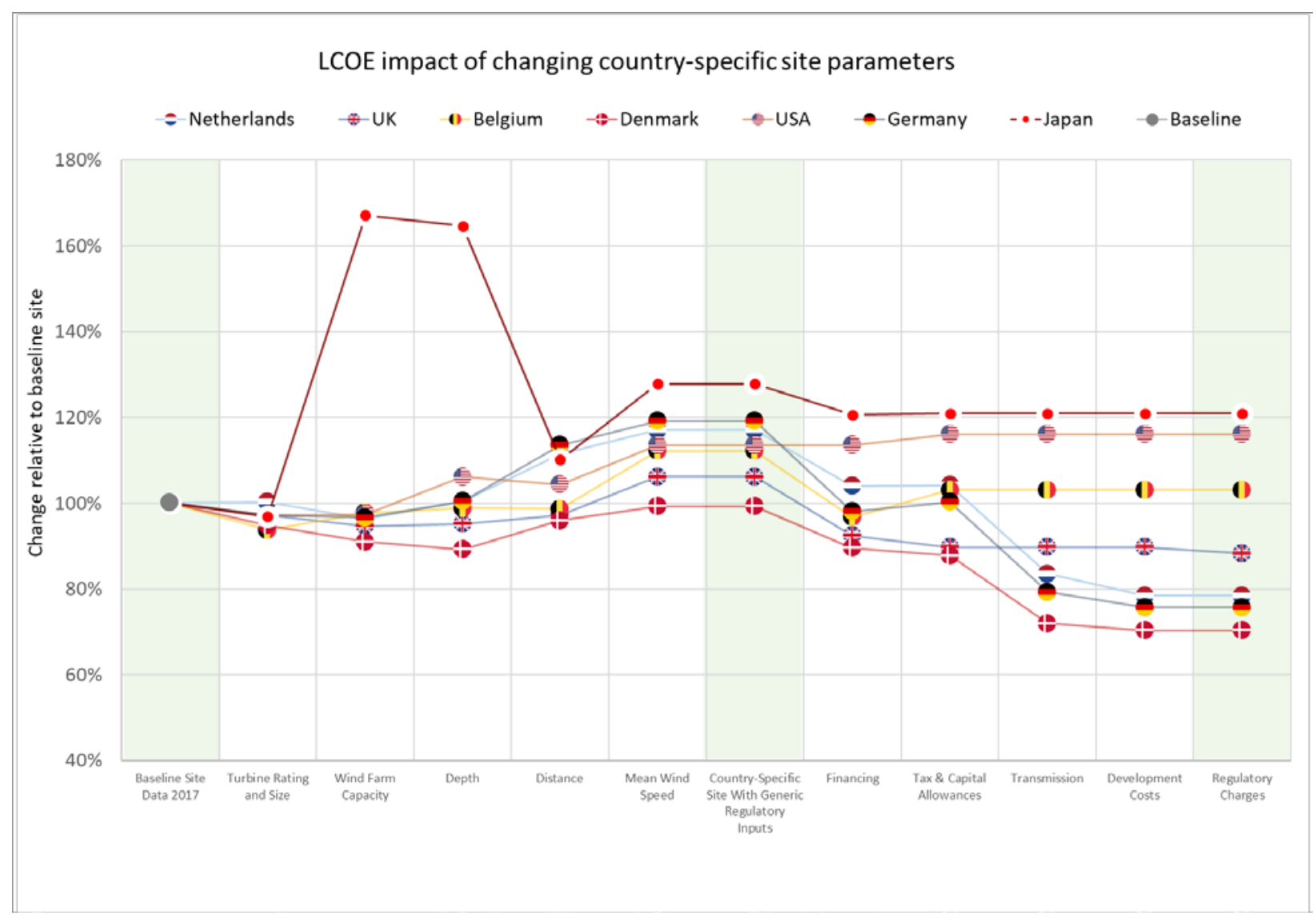

Figure 18. LCOE impact of changing country-specific parameters 


\subsection{Key Site and Technology Inputs}

A summary of the key site and technology parameters used in representative country sites is presented in Table 12.

Table 12. Site Parameters for All Countries in the Study

\begin{tabular}{|c|c|c|c|c|c|c|c|c|c|}
\hline Scenario Element & Unit & $\begin{array}{c}2017 \\
\text { Baseline }\end{array}$ & $\begin{array}{l}\text { Netherla } \\
\text { nds }\end{array}$ & UK & Belgium & Denmark & USA & Germany & Japan \\
\hline LCOE & $\begin{array}{l}€ / M \\
\text { Wh }\end{array}$ & 130.4 & 107.2 & 116.3 & 142.7 & 93.2 & 155.5 & 106.3 & 166.7 \\
\hline Turbine numbers & $\#$ & 100 & 150 & 69 & 42 & 50 & 76 & 60 & 14 \\
\hline Turbine rating & MW & $4 \mathrm{MW}$ & $4 \mathrm{MW}$ & $6 \mathrm{MW}$ & $7 \mathrm{MW}$ & $8 \mathrm{MW}$ & $6 \mathrm{MW}$ & $6 \mathrm{MW}$ & $5.2 \mathrm{MW}$ \\
\hline Hub height & $\mathrm{m}$ & 90 & 89 & 100 & 106 & 105 & 100 & 100 & 127 \\
\hline Rotor diameter & $\mathrm{m}$ & 100 & 130 & 154 & 154 & 164 & 154 & 154 & 136 \\
\hline Windfarm capacity & MW & $400 \mathrm{MW}$ & $600 \mathrm{MW}$ & $414 \mathrm{MW}$ & $294 \mathrm{MW}$ & $400 \mathrm{MW}$ & $456 \mathrm{MW}$ & $360 \mathrm{MW}$ & $72.8 \mathrm{MW}$ \\
\hline $\begin{array}{l}\text { Turbine foundation } \\
\text { type }\end{array}$ & text & monopile & monopile & monopile & monopile & monopile & jacket & monopile & monopile \\
\hline Array cable type & text & $\begin{array}{c}33 \mathrm{kV}, 185 \\
\mathrm{~mm}^{2}\end{array}$ & $\begin{array}{c}33 \mathrm{kV}, 185 \\
\mathrm{~mm}^{2}\end{array}$ & $\begin{array}{c}33 \mathrm{kV}, 185 \\
\mathrm{~mm}^{2}\end{array}$ & $\begin{array}{c}33 \mathrm{kV}, 185 \\
\mathrm{~mm}^{2}\end{array}$ & $\begin{array}{c}33 \mathrm{kV}, 185 \\
\mathrm{~mm}^{2}\end{array}$ & $\begin{array}{c}33 \mathrm{kV}, 185 \\
\mathrm{~mm}^{2}\end{array}$ & $\begin{array}{c}33 \mathrm{kV}, 185 \\
\mathrm{~mm}^{2}\end{array}$ & $\begin{array}{c}33 \mathrm{kV}, 185 \\
\mathrm{~mm}^{2}\end{array}$ \\
\hline $\begin{array}{l}\text { No. offshore } \\
\text { substations }\end{array}$ & \# & 1 & 2 & 1 & 1 & 1 & 1 & 1 & N/A \\
\hline $\begin{array}{l}\text { Substation foundation } \\
\text { type }\end{array}$ & text & jacket & monopile & monopile & monopile & monopile & jacket & monopile & N/A \\
\hline $\begin{array}{l}\text { Foundation per } \\
\text { substation }\end{array}$ & $\#$ & 1 & 1 & 1 & 1 & 1 & 2 & 1 & N/A \\
\hline $\begin{array}{l}\text { Offshore export cable } \\
\text { rating }\end{array}$ & text & $\begin{array}{c}220 \mathrm{kV} \\
1,000 \\
\mathrm{~mm}^{2}\end{array}$ & $\begin{array}{c}220 \mathrm{kV} \\
1,000 \\
\mathrm{~mm}^{2}\end{array}$ & $\begin{array}{c}220 \mathrm{kV} \\
1,000 \\
\mathrm{~mm}^{2}\end{array}$ & $\begin{array}{c}220 \mathrm{kV} \\
1,000 \\
\mathrm{~mm}^{2}\end{array}$ & $\begin{array}{c}220 \mathrm{kV} \\
1,000 \\
\mathrm{~mm}^{2}\end{array}$ & $\begin{array}{c}220 \mathrm{kV} \\
1,000 \\
\mathrm{~mm}^{2}\end{array}$ & $\begin{array}{c}220 \mathrm{kV} \\
1,000 \\
\mathrm{~mm}^{2}\end{array}$ & $\begin{array}{c}33 \mathrm{kV}, 400 \\
\mathrm{~mm}^{2}\end{array}$ \\
\hline $\begin{array}{l}\text { Onshore export cable } \\
\text { rating }\end{array}$ & text & $\begin{array}{c}220 \mathrm{kV} \\
1,000 \\
\mathrm{~mm}^{2}\end{array}$ & $\begin{array}{c}220 \mathrm{kV} \\
1,000 \\
\mathrm{~mm}^{2}\end{array}$ & $\begin{array}{c}220 \mathrm{kV} \\
1,000 \\
\mathrm{~mm}^{2}\end{array}$ & $\begin{array}{c}220 \mathrm{kV} \\
1,000 \\
\mathrm{~mm}^{2}\end{array}$ & $\begin{array}{c}220 \mathrm{kV} \\
1,000 \\
\mathrm{~mm}^{2}\end{array}$ & $\begin{array}{c}220 \mathrm{kV} \\
1,000 \\
\mathrm{~mm}^{2}\end{array}$ & $\begin{array}{c}220 \mathrm{kV} \\
1,000 \\
\mathrm{~mm}^{2}\end{array}$ & $\begin{array}{c}33 \mathrm{kV}, 500 \\
\mathrm{~mm}^{2}\end{array}$ \\
\hline Water depth & $\mathrm{m}$ & 25 & 33 & 27 & 29 & 16 & 30 & 35 & 11.9 \\
\hline $\begin{array}{l}\text { Distance to construction } \\
\text { port }\end{array}$ & $\mathrm{km}$ & 40 & 78 & 25 & 33 & 60 & 30 & 80 & 20 \\
\hline Distance to O\&M port & $\mathrm{km}$ & 40 & 78 & 25 & 33 & 50 & 30 & 60 & 70 \\
\hline $\begin{array}{l}\text { Distance to cable } \\
\text { landfall }\end{array}$ & $\mathrm{km}$ & 40 & 120 & 50 & 40 & 33 & 30 & 60 & 3.4 \\
\hline Onshore cable distance & $\mathrm{km}$ & 10 & 10 & 18 & 10 & 50 & 10 & 60 & 3 \\
\hline Mean wind speed & $\mathrm{m} / \mathrm{s}$ & 9.90 & 9.36 & 9.15 & 8.95 & 9.57 & 8.99 & 9.47 & 8.67 \\
\hline Wave conditions & text & medium & medium & medium & harsh & medium & mild & medium & medium \\
\hline Seabed conditions & text & normal & normal & normal & normal & normal & normal & normal & normal \\
\hline
\end{tabular}

\subsubsection{Water Depth}

Across the global sites chosen, average water depth is broadly similar. Japan and Denmark stand out as particularly shallow sites, which contributes to Denmark's low cost of energy, along with the high wind speeds found at that site. However, the benefit of a shallow site in Japan is far outweighed by the impact of a small site capacity. Belgium is the only country with harsh wave conditions. Within the Cost Model, this increases installation cost and O\&M costs as a result of vessel delays. 
Figure 20 shows the LCOE impact of changing water depth. The dotted line represents the trendline of how LCOE changes as water depth increases on the baseline site in the absence of any external changes that are apparent in the other sites.

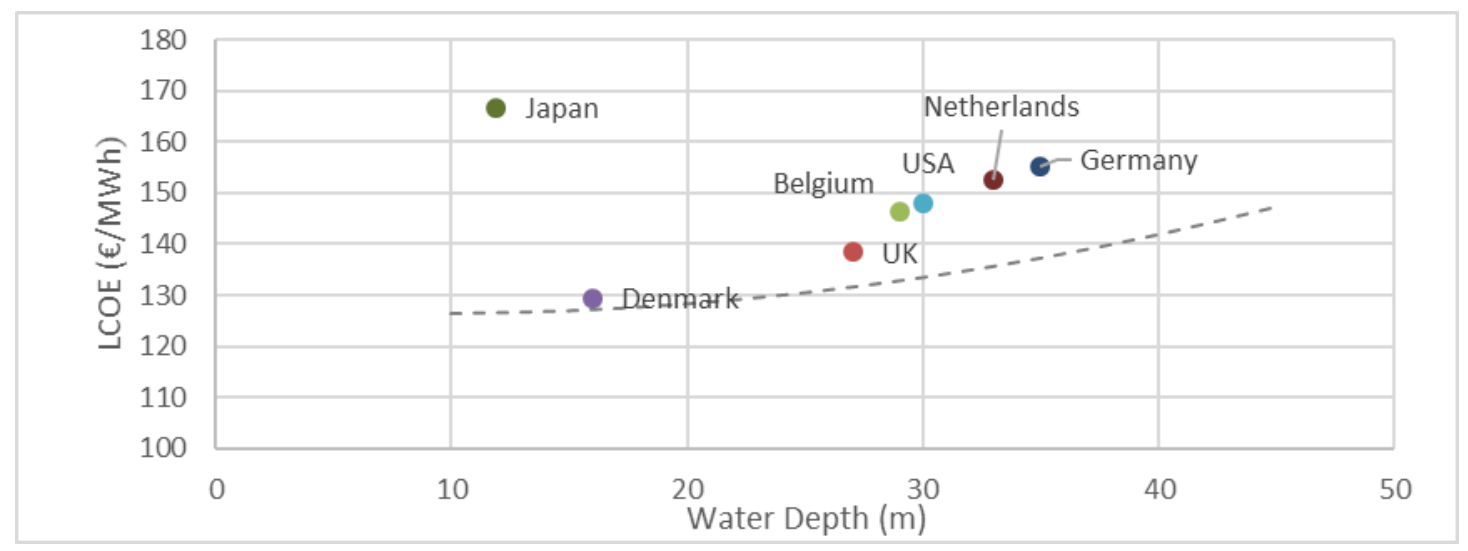

Figure 19. Water depth against LCOE for modelled sites and impact of changing baseline water depth

\subsubsection{Distance to Shore}

Separate distances are recorded for distance to construction port, O\&M port, and cable landfall for each of the sites. In most cases, distances to each of the ports are similar and cable landfall is slightly further than to either port. Figure 21 shows a very small increase in LCOE because of distance to port. Vessel journeys to shore take several hours; however, vessel lease is rounded to the nearest number of days, so in each campaign there is only a small difference in vessel cost.

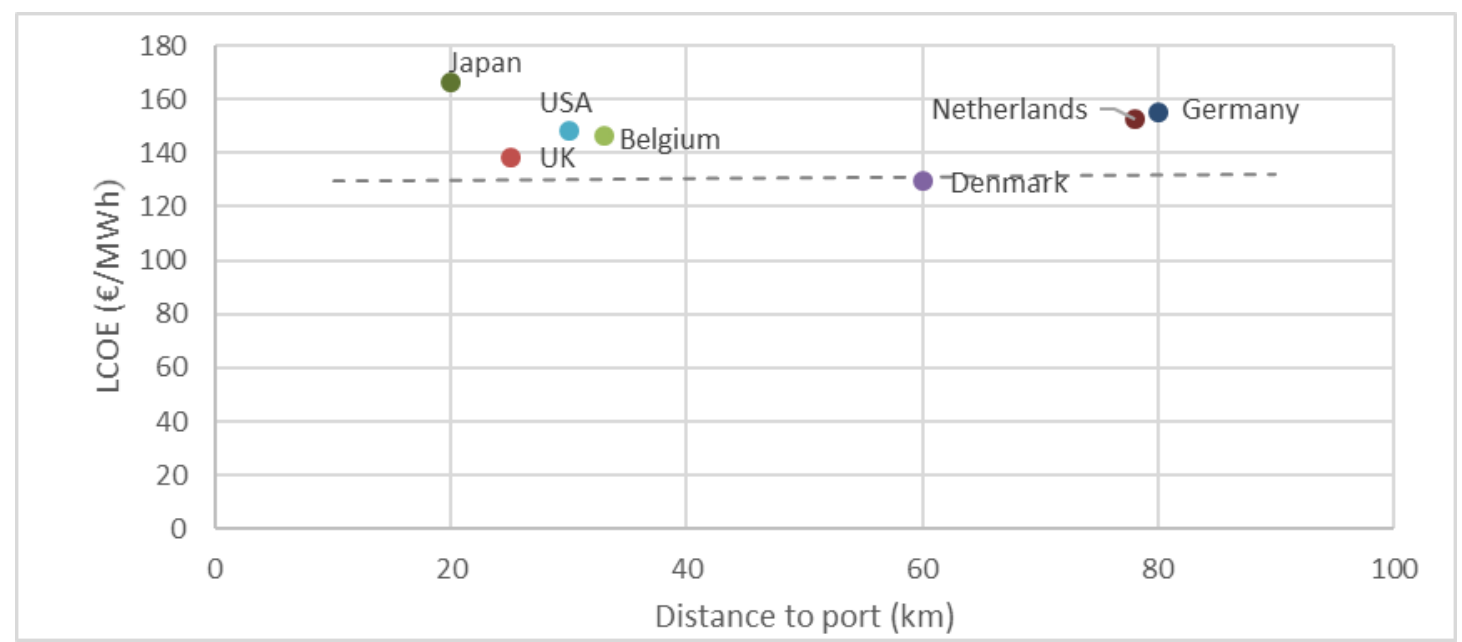

Figure 20. Distance to port against LCOE for modelled sites and impact of changing baseline distance to port 


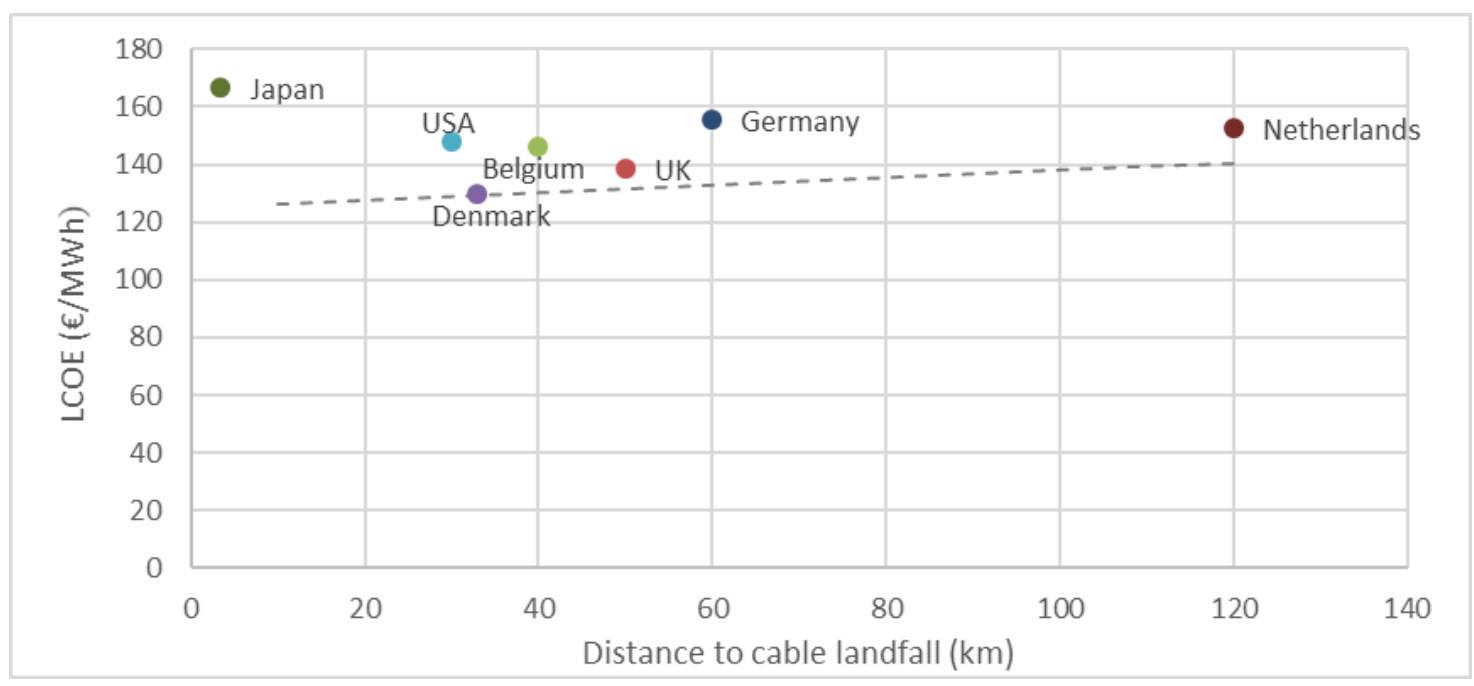

Figure 21. Distance to cable landfall against LCOE for modelled sites and impact of changing baseline distance-to-cable landfall

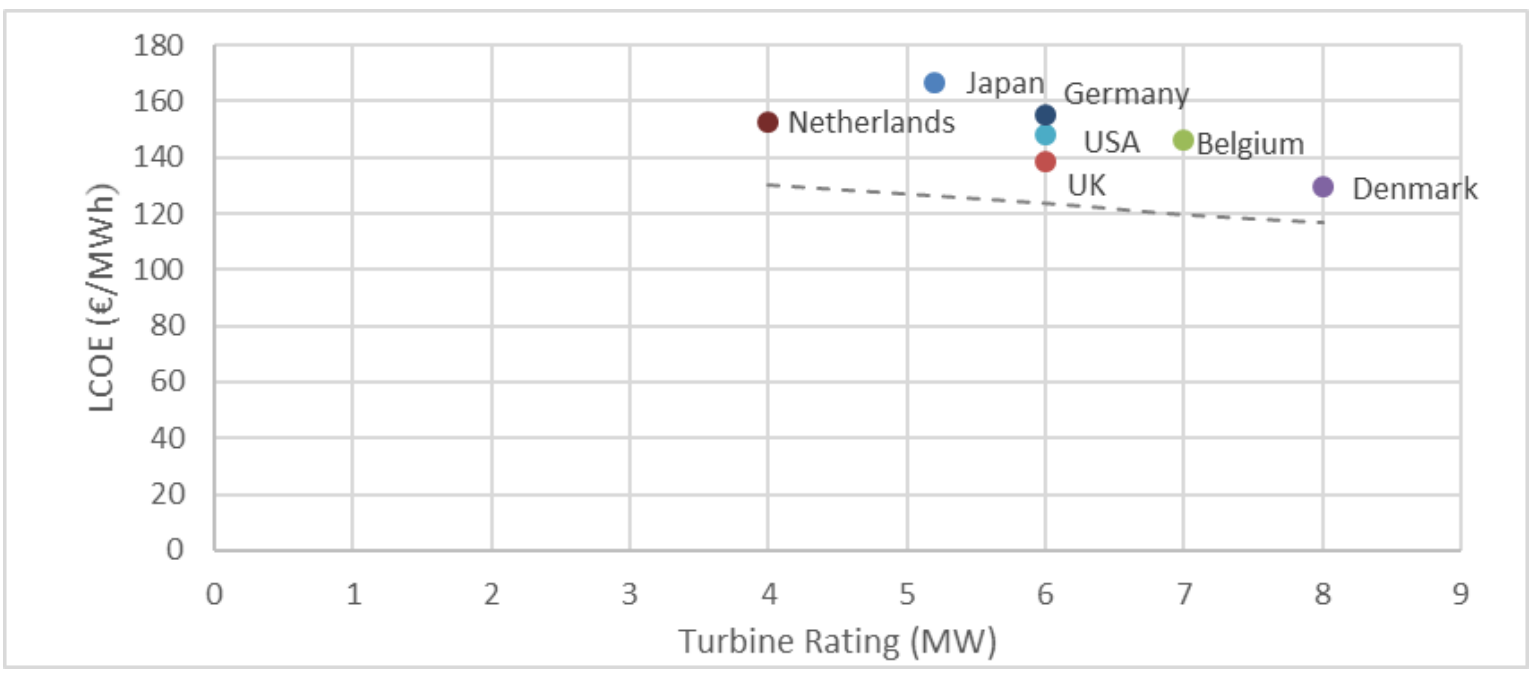

Figure 22. Turbine rating against LCOE for modelled sites

Distance to cable landfall has a bigger impact on LCOE than distance to port, as demonstrated in Figure 22. The steeper gradient on the baseline impact shows that there is a larger LCOE impact because of the additional cable length required. Export cable costs are $€ 800 / \mathrm{m}$, so a difference of $10 \mathrm{~km}$ to $120 \mathrm{~km}$ cabling is an additional capital cost of $€ 88 \mathrm{~m}$. It is worth noting that the site farthest from cable landfall (Netherlands), as well as closer sites like Denmark and Germany, all exclude transmission cost from the final LCOE for developers. Transmission costs are socialised, and as such, would not cause a financial impact directly to the developers. The Netherlands site is not representative of more recently consented sites and upcoming projects are situated much closer to shore - ranging between 20 and $22 \mathrm{~km}$ - in line with the average global distance to shore. As previously discussed, the 73-MW Japan site is $3 \mathrm{~km}$ from shore. It is expected that developers would take advantage of the short distance and move electrical equipment from offshore to an onshore substation.

\subsubsection{Turbine Ratings}

The majority of offshore wind sites are using turbine ratings higher than the 4-MW baseline site, showing the fast uptake of new technology in this area. Turbine rating has a large impact on 
foundation, cable, and O\&M costs. Figure 23 shows a slight negative correlation across turbine rating and LCOE.

\subsubsection{Foundation}

Below a water depth of approximately $30 \mathrm{~m}$, monopile foundations are the standard choice. At higher water depths of up to $40 \mathrm{~m}$, monopiles may still be feasible, but many developers choose larger foundations, such as jacket- or gravity-based. The United States is the only country that uses jacket foundations, despite Germany being at a similar water depth. The United States has an existing oil and gas industry with expertise in jacket-style manufacturing, which can be transferred to similar offshore wind foundations. For the comparison in Figure 20, the baseline site is assumed to continue to use monopiles in deeper water. A comparison with jackets would see jacket foundations as significantly more expensive in shallower waters and comparable in cost in water depths of $40-50 \mathrm{~m}$.

\subsubsection{Electrical Systems}

Electrical systems are consistent across all the representative sites in using $33-\mathrm{kV}$ array cables. Projects taking a FID in 2017 are more frequently using 66-kV cables. Export cables are typically $220 \mathrm{kV}$; however, Japan has a single array cable/export system at $33 \mathrm{kV}$ as onshore transformers step up voltages to the grid.

\subsection{Key Finance and Regulatory Regime Inputs}

The impact of the financial and regulatory regimes local to each site is significant. Table 13 gives a summary of the country-specific financial inputs used in the Task 26 Cash Flow Model. Globally, return expectations are decreasing as competition increases through auctions, thereby providing a lower LCOE; however, there are many other factors that are apparent in this study.

Table 13. Financial Inputs Summary

\begin{tabular}{|l|c|c|c|c|c|c|c|c|c|}
\hline Financial Inputs & \multicolumn{2}{|c|}{$\begin{array}{c}2017 \\
\text { Baseline }\end{array}$} & Netherlands & UK & Belgium & Denmark & USA & Germany & Japan \\
\hline Debt/equity ratio & $\%$ & $70.0 \%$ & $70.0 \%$ & $70.0 \%$ & $75.0 \%$ & $70.0 \%$ & $55.0 \%$ & $75.0 \%$ & $70.0 \%$ \\
\hline Cost of equity & $\%$ & $15.0 \%$ & $13.0 \%$ & $12.5 \%$ & $13.0 \%$ & $12.8 \%$ & $12.1 \%$ & $12.0 \%$ & $15.0 \%$ \\
\hline Cost of debt & $\%$ & $5.0 \%$ & $4.0 \%$ & $4.0 \%$ & $5.0 \%$ & $4.8 \%$ & $6.8 \%$ & $4.0 \%$ & $3.0 \%$ \\
\hline $\begin{array}{l}\text { WACC (pretax } \\
\text { nominal) }\end{array}$ & $\%$ & $7.1 \%$ & $6.70 \%$ & $6.55 \%$ & $7.00 \%$ & $7.15 \%$ & $9.16 \%$ & $6.00 \%$ & $5.98 \%$ \\
\hline & & & & & & & & & \\
\hline Annual inflation & $\%$ & $1.8 \%$ & $1.8 \%$ & $1.8 \%$ & $1.8 \%$ & $1.8 \%$ & $1.8 \%$ & $1.8 \%$ & $1.8 \%$ \\
\hline WACC (pretax real) & $\%$ & $4.67 \%$ & $4.81 \%$ & $4.67 \%$ & $5.11 \%$ & $5.26 \%$ & $7.23 \%$ & $4.13 \%$ & $2.65 \%$ \\
\hline
\end{tabular}

Figure 24 shows the LCOE impact of individual countries' financial and regulatory regime on each site by comparing LCOE when all sites use the baseline regime and the LCOE using each countries' regime. Although Denmark remains the country with the lowest LCOE, things are markedly different at the other end of the spectrum. Depending on site conditions alone, the Japan site has the highest LCOE. The attractive financial market reduces the WACC to $4.5 \%$, giving a lower LCOE at that site. Even more drastically, the combination of the second lowest 
WACC (6.0\%), reduced development costs, and socialised transmission cost brings Germany to second place after local financial regime is considered.

In contrast, the U.S. site moves down the list because of a much higher debt interest rate than other countries, which coincides with a choice to use a lower debt ratio. From projects that would have been commissioned in 2017 and 2018, the United States also has a higher corporate tax rate than any other country in the study.

Each of these factors is examined further in this section. Figures 24-26 show the final LCOE of each country with a sensitivity analysis on the baseline site with only the relevant input varied.

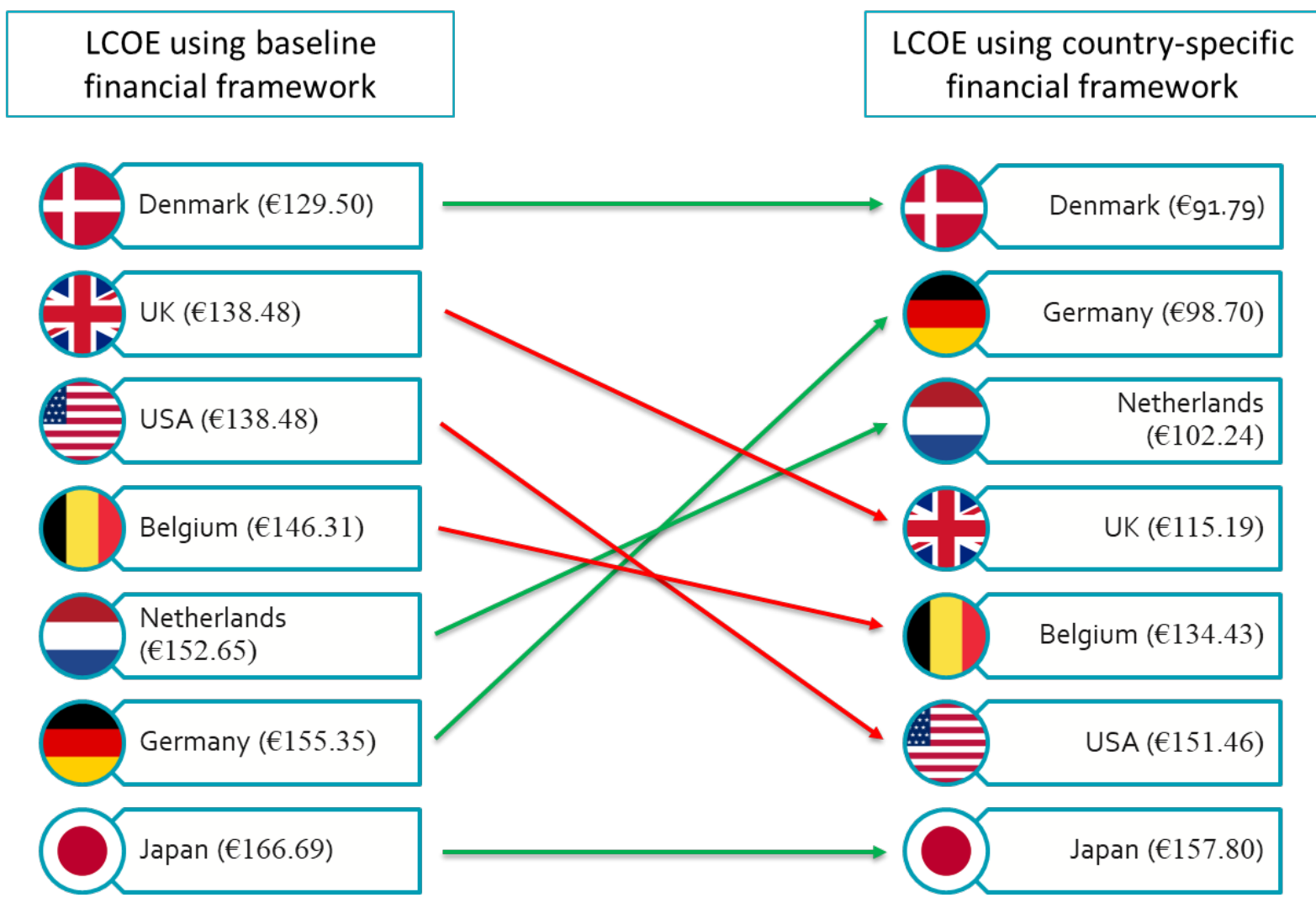

Figure 23. Impact of country-specific financial framework on LCOE

\subsubsection{Weighted Average Cost of Capital}

The WACC is made of several moving parts. Increasing cost of debt (Figure 25) has a strong correlation with increasing LCOE. Most countries have rates between 4\% and 6\%, with Japan and the United States as clear outliers. The equity return rate (Figure 26) has an even stronger correlation with LCOE. Because debt rates are typically lower than equity return expectation, it follows that as the proportion of debt funding a project decreases, there is a negative correlation with LCOE as shown in Figure 27. 


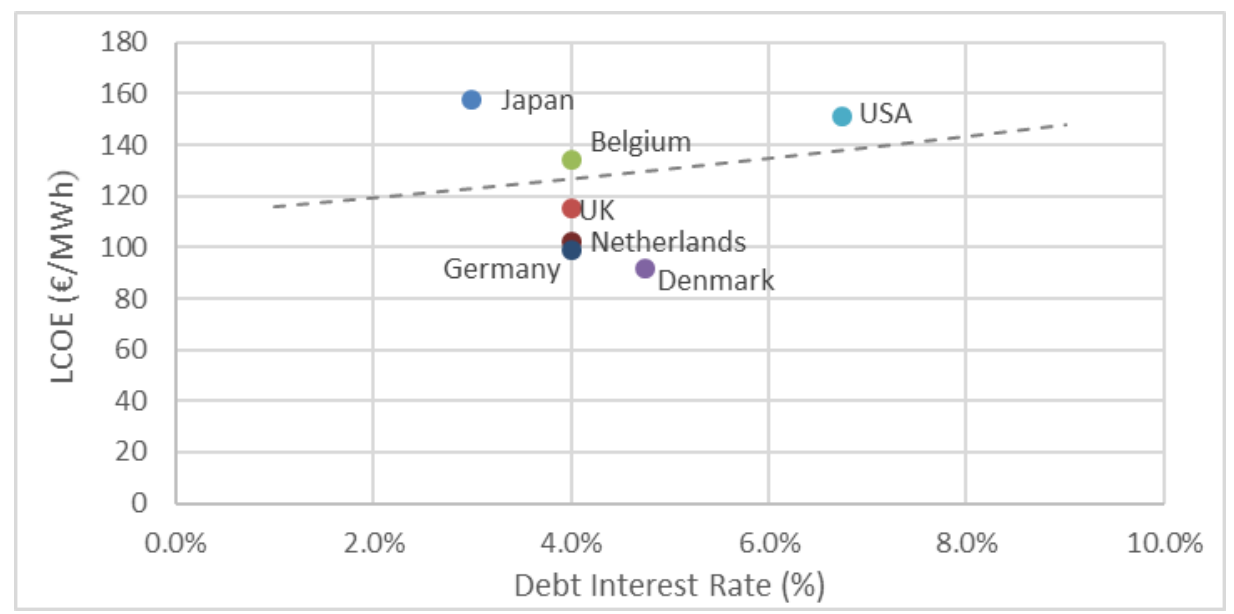

Figure 24. Debt interest rate against LCOE for modelled sites and impact of changing baseline debt interest rate

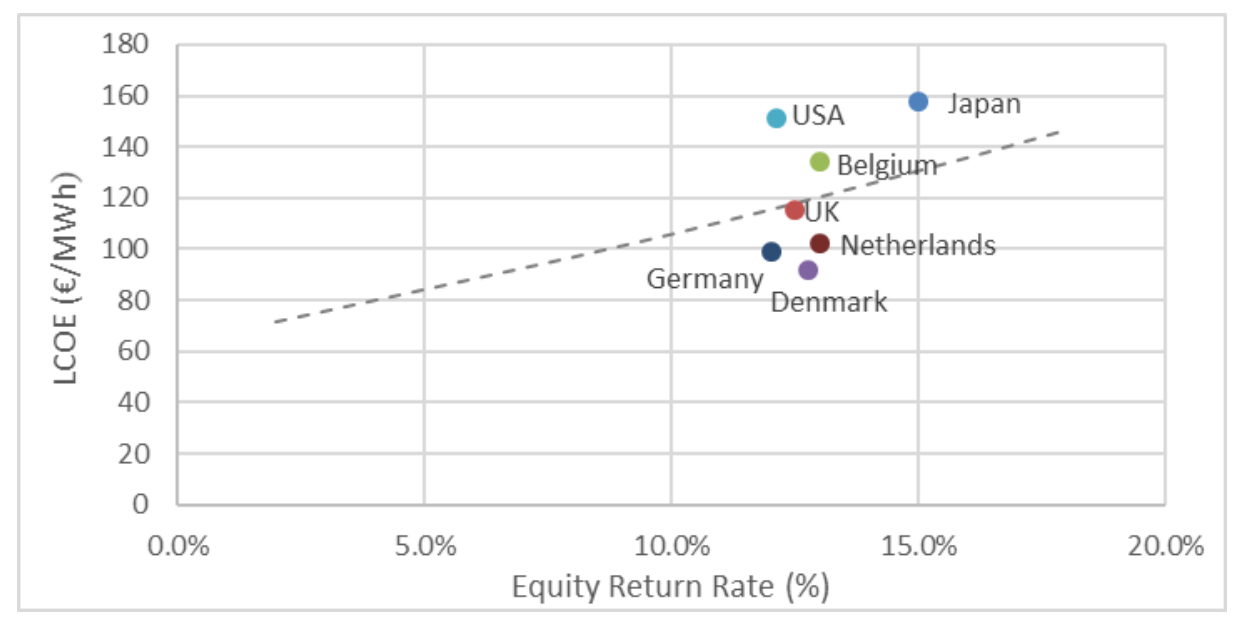

Figure 25. Equity return against LCOE for modelled sites and impact of changing baseline equity return

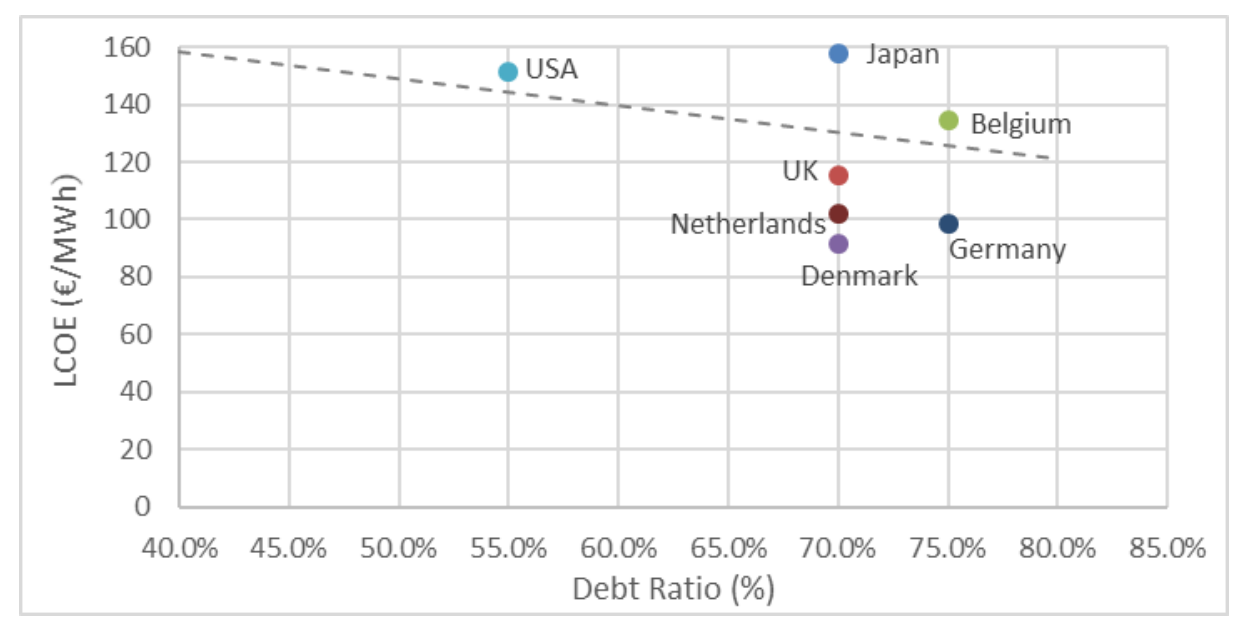

Figure 26. Debt ratio against LCOE for modelled sites and impact of changing baseline debt ratio 


\subsubsection{Tax Rate and Regulation}

The country-specific regimes for offshore wind development vary widely across countries (Figure 28), with an average tax rate of $28 \%$. More significantly is the centralisation of certain aspects of a project. In Denmark, Germany, and the Netherlands, grid connection is provided by third-party grid operators, which removes $21 \%-24 \%$ of CAPEX. Additionally, much of the high risk early development costs in these countries are borne by the government, which again reduces the upfront costs to the developer. The United Kingdom has a unique system of an OFTO operator lease (explained further in Section 5.4.3) and is also the only country to pay additional seabed leasing charges.

Centralising development costs can remove considerable project risk for a developer. The site has permits in place and well-understood site conditions. However, centralising the grid connection system can introduce additional risk during construction, as delays in the schedule of grid connection commissioning can delay revenue generation for a developer, and does not provide the ability to accelerate the work plan.

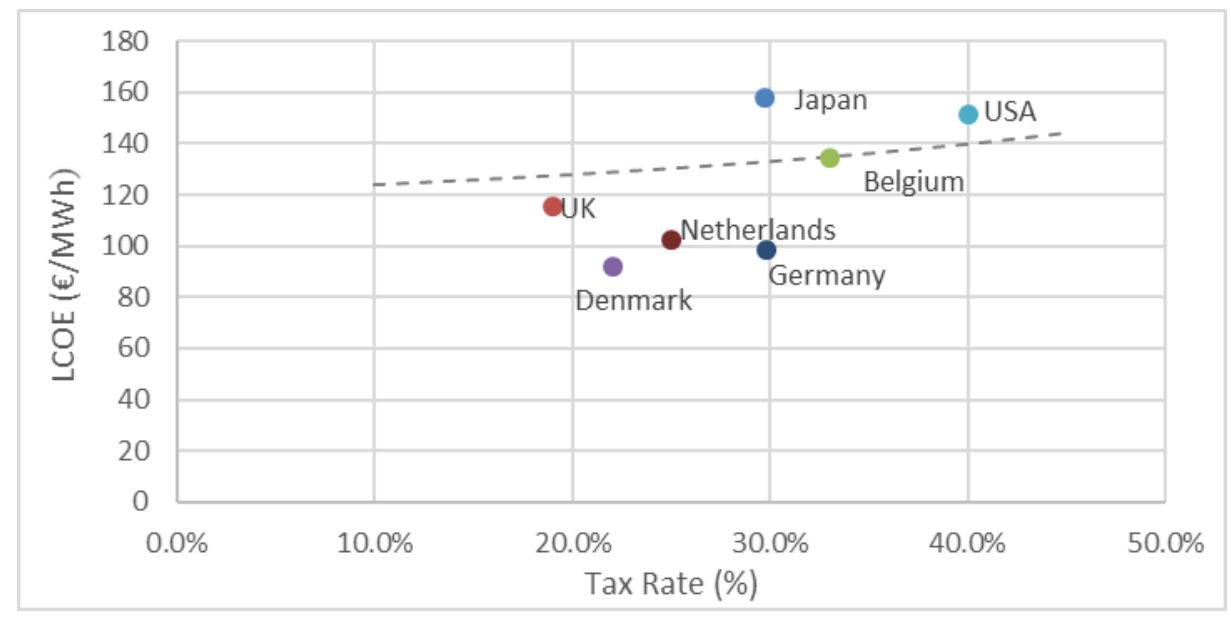

Figure 27. Tax rate against LCOE for modelled sites and impact of changing baseline tax rate

\subsection{CAPEX and OPEX Estimates}

In relation to the site parameters and technology choices outlined in Table 12, there are many moving parts in the CAPEX and OPEX breakdown. The same cost buildup has been used across all sites. No assumptions have been made for local access to supply chain or synergies from clustered wind farms working together. Table 14 summarises the final relative CAPEX and OPEX costs of representative sites in each country. The cells in blue denote transmission costs that are not paid by the developer in these regimes. 
Table 14. CAPEX and OPEX Comparison for All Countries in the Study

\begin{tabular}{|c|c|c|c|c|c|c|c|c|}
\hline $\begin{array}{l}\text { Valuation Model } \\
\text { Inputs Summary - } \\
\text { Cost }\end{array}$ & $\begin{array}{c}2017 \\
\text { Baseline }\end{array}$ & Netherlands & UK & Belgium & Denmark & USA & Germany & Japan \\
\hline $\begin{array}{l}\text { Capex Inputs } \\
\text { Summary }\end{array}$ & $€ / \mathbf{k W}$ & $€ / \mathbf{k W}$ & $€ / \mathbf{k W}$ & $€ / \mathbf{k W}$ & $€ / \mathbf{k W}$ & $€ / \mathbf{k W}$ & $€ / k W$ & $€ / \mathbf{k W}$ \\
\hline Turbine supply & 1,300 & 1,300 & 1,420 & 1,450 & 1,490 & 1,420 & 1,420 & 1,365 \\
\hline Turbine installation & 162 & 166 & 110 & 111 & 97 & 98 & 118 & 184 \\
\hline Turbine Subtotal & 1,462 & 1,466 & 1,530 & 1,561 & 1,587 & 1,518 & 1,538 & 1,549 \\
\hline Foundation supply & 551 & 685 & 517 & 463 & 389 & 518 & 627 & 406 \\
\hline $\begin{array}{l}\text { Foundation } \\
\text { installation }\end{array}$ & 210 & 206 & 145 & 144 & 113 & 374 & 148 & 237 \\
\hline $\begin{array}{l}\text { Foundation } \\
\text { Subtotal }\end{array}$ & 762 & 891 & 662 & 608 & 502 & 892 & 775 & 643 \\
\hline Array cable supply & 43 & 55 & 47 & 43 & 42 & 48 & 48 & 19 \\
\hline $\begin{array}{l}\text { Array cable } \\
\text { installation }\end{array}$ & 117 & 116 & 79 & 80 & 60 & 66 & 80 & 107 \\
\hline $\begin{array}{l}\text { Offshore substation } \\
\text { supply \& install }\end{array}$ & 186 & 237 & 178 & 252 & 185 & 160 & 207 & $\mathrm{~N} / \mathrm{A}$ \\
\hline Export cable supply & 138 & 388 & 187 & 187 & 304 & 179 & 447 & 188 \\
\hline Export cable install & 62 & 193 & 83 & 96 & 122 & 71 & 186 & 198 \\
\hline $\begin{array}{l}\text { Onshore substation } \\
\& \text { grid connection }\end{array}$ & 93 & 91 & 88 & 122 & 94 & 68 & 119 & 425 \\
\hline $\begin{array}{l}\text { Electrical } \\
\text { Infrastructure } \\
\text { Subtotal }\end{array}$ & 638 & 1,081 & 662 & 780 & 806 & 591 & 1,087 & 937 \\
\hline $\begin{array}{l}\text { Construction } \\
\text { insurance }\end{array}$ & 45 & 45 & 45 & 45 & 45 & 45 & 45 & 45 \\
\hline $\begin{array}{l}\text { Project } \\
\text { management }\end{array}$ & 145 & 174 & 145 & 150 & 147 & 152 & 172 & 159 \\
\hline Contingency & 305 & 366 & 304 & 314 & 309 & 320 & 362 & 333 \\
\hline $\begin{array}{l}\text { Other CAPEX } \\
\text { Subtotal }\end{array}$ & 496 & 585 & 494 & 509 & 501 & 517 & 579 & 537 \\
\hline $\begin{array}{l}\text { Total Construction } \\
\text { CAPEX }\end{array}$ & 3,358 & 4,023 & 3,349 & 3,458 & 3,395 & 3,518 & 3,979 & 3,666 \\
\hline $\begin{array}{l}\text { OPEX Inputs } \\
\text { Summary }\end{array}$ & $€ / \mathrm{kW}$ & $€ / k W$ & $€ / k W$ & $€ / k W$ & $€ / k W$ & $€ / k W$ & $€ / k W$ & $€ / \mathbf{k W}$ \\
\hline Major repairs & 31 & 29 & 24 & 25 & 20 & 22 & 26 & 58 \\
\hline Minor repairs & 13 & 13 & 14 & 14 & 14 & 14 & 14 & 14 \\
\hline $\begin{array}{l}\text { Preventive } \\
\text { maintenance }\end{array}$ & 5 & 5 & 5 & 5 & 5 & 4 & 5 & 5 \\
\hline $\begin{array}{l}\text { Fixed operating } \\
\text { costs }\end{array}$ & 11 & 4 & 4 & 5 & 5 & 4 & 5 & 16 \\
\hline Operating insurance & 17 & 17 & 17 & 17 & 17 & 17 & 17 & 17 \\
\hline Total Annual OPEX & 77 & 69 & 64 & 66 & 60 & 61 & 67 & 110 \\
\hline Turbine Availability & $94.0 \%$ & $94.9 \%$ & $94.3 \%$ & $95.3 \%$ & $95.3 \%$ & $95.2 \%$ & $94.5 \%$ & $95.6 \%$ \\
\hline
\end{tabular}

\subsection{Annual Energy Generation Estimates}

The annual energy generation for each project depends on turbine rating and site capacity. The output of each country representative site is presented in Table 15. Mean wind speed at hub 
height and wake losses are estimated by the DTU WaSP model. Additional losses have been applied uniformly across sites using a precedent from operating wind farms.

Table 15. Energy Output of Representative Sites in Each Country

\begin{tabular}{|l|l|c|c|c|c|c|c|c|c|}
\hline $\begin{array}{l}\text { Electricity } \\
\text { Generation }\end{array}$ & $\begin{array}{c}2017 \\
\text { Baseline }\end{array}$ & Netherlands & UK & Belgium & Denmark & USA & Germany & Japan \\
\hline $\begin{array}{l}\text { Gross annual } \\
\text { energy } \\
\text { production }\end{array}$ & $\begin{array}{l}\text { Giga- } \\
\text { watth } \\
\text { ours }\end{array}$ & 2,006 & 1,854 & 1,289 & 1,926 & 2,184 & 1,676 & 1,006 & 2,900 \\
\hline $\begin{array}{l}\text { Gross } \\
\text { capacity } \\
\text { factor }\end{array}$ & $\%$ & $57.22 \%$ & $51.09 \%$ & $50.00 \%$ & $54.92 \%$ & $50.04 \%$ & $53.11 \%$ & $57.40 \%$ & $55.14 \%$ \\
\hline Wake losses & $\%$ & $11.37 \%$ & $9.61 \%$ & $9.13 \%$ & $10.04 \%$ & $10.75 \%$ & $9.02 \%$ & $10.04 \%$ & $9.55 \%$ \\
\hline $\begin{array}{l}\text { Electrical } \\
\text { losses }\end{array}$ & $\%$ & $2.00 \%$ & $2.00 \%$ & $2.00 \%$ & $2.00 \%$ & $2.00 \%$ & $2.00 \%$ & $2.00 \%$ & $2.00 \%$ \\
\hline Other losses & $\%$ & $1.00 \%$ & $1.00 \%$ & $1.00 \%$ & $1.00 \%$ & $1.00 \%$ & $1.00 \%$ & $1.00 \%$ & $1.00 \%$ \\
\hline Availability & $\%$ & $94.22 \%$ & $94.87 \%$ & $94.25 \%$ & $95.30 \%$ & $95.32 \%$ & $94.54 \%$ & $94.00 \%$ & $94.44 \%$ \\
\hline
\end{tabular}




\section{Future Trends}

Technology is changing quickly in the offshore wind industry and projects with a FID in 2017 vary drastically from sites being commissioned in 2017. Recently announced auction results across Europe show LCOE expectations far below the numbers quoted here. This cost reduction can be attributed to progress in several main areas of innovation and market maturity, including:

- Larger turbines. The key cost reductions triggered by a move to turbines $10 \mathrm{MW}$ and up are in lower balance-of-plant and O\&M costs. It is likely that even higher capacity factors can also be enabled.

- Higher capacity factors. Industry feedback is that turbine capacity factors are expected to rise over the next few years as the current generation of 6-MW+ turbines are optimised and integrated wind farm control systems improve.

- Longer life of assets. In some countries, regulations now allow for sites to be operated for 30 years (provided any necessary updates to existing licenses are granted). Although this is a regulatory enabler, it is a technological innovation that will give confidence to project developers and financers that a 30-year design life for the entire offshore wind farm can be achieved.

- Autonomous inspection and predictive maintenance. Drones and remotely operated vehicles are being used more often to inspect wind farms. This reduces turbine downtime, reduces health and safety risk, and is cheaper to perform, allowing for more frequent inspections. Operators are using more sophisticated structural health monitoring and wind farm controls to optimise turbine performance, which can also mean using a precedence of older operating wind farms to better predict component life and optimal maintenance strategy.

- Several large owner/operators are beginning to dominate the market. The idea of wind farm clusters and even creating multi-wind farm offshore bases has been gaining momentum in recent years. Both EnBW (synergies with the upcoming Hohe See and Albatros sites) and Ørsted (synergies with existing Borkum Riffgrund $1 \& 2$ sites) have cited the ability to service a number of wind farms from a single base as a driver of lower costs in their subsidy-free bids. Savings would be expected from sharing fixed onshore costs across multiple projects, as well as being able to schedule maintenance and repair tasks more efficiently and spread the fixed cost element of expensive vessels for major repairs over a greater number of units.

- Lower WACC. Low underlying cost of finance and the increasing acceptance of offshore wind as a mature asset class with a well-understood risk profile mean that the cost of capital can become a smaller part of the overall LCOE.

The recent awards of 1,380 MW offshore wind capacity in Germany and $700 \mathrm{MW}$ of offshore wind capacity in the Netherlands (without subsidy) represent landmark moments for the industry. These projects combine good site conditions with high wind speeds and a competitive market, including socialised grid connection costs. The projects are expected to be commissioned in 2022 for the Netherlands and 2024-2025 in Germany, giving time for technology to move forward. In particular, developers have specifically stated that they expect turbines in the range of 13-15 MW to be available for commercial deployment for 2024 projects.

Within transmission, Germany is using high-voltage direct-current hubs to efficiently transport power to shore for future sites, and some developers and original equipment manufacturers are 
also exploring a new slimmed-down substation design. Export cables are also expanding in capacity to accommodate increasingly large sites.

In the longer term, there is an expectation that developers will seek higher wind speeds found in sites with more difficult conditions - deeper water and farther from shore-but floating wind turbines may be commercially ready to meet this challenge in the next 10 years. 


\section{References}

Agency for Natural Resources and Energy. "Welcome! Renewable Energy." http://www.enecho.meti.go.jp/category/saving_and_new/saiene/kaitori/kakaku.html

Beiter, P., P. Spitsen, J. Nunemaker, T. Tian, W. Musial, E. Lantz. 2018 (forthcoming). 2017 Offshore Wind Technologies Market Update. U.S. Department of Energy, Washington, D.C. (US).

Bloomberg New Energy Finance. “1H 2017 Wind LCOE Update.” (Through subscription). 2017.

Bureau of Ocean Energy Management. "Rules Development and Interim Policy." https://www.boem.gov/Rules-Development/

Cherrier, S. 2014. Financing offshore wind - the Gemini project. https://greengiraffe.eu/file/1423/colorbox?width=900px.

Dredging, Environmental \& Marine Engineering. 2018. "RENTEL NV reaches Financial Close for its 309 MW Offshore wind project in the Belgian North Sea." https://www.demegroup.com/news/rentel-nv-reaches-financial-close-its-309-mw-offshore-wind-project-belgiannorth-sea

Ernst \& Young. 2009. Cost of and financial support for offshore wind. Prepared for the Department of Energy and Climate Change.

http://webarchive.nationalarchives.gov.uk/+/http:/www.berr.gov.uk/files/file51142.pdf

Fraunhofer IEE Wind Energy Report. 2017.

http://windmonitor.iee.fraunhofer.de/opencms/export/sites/windmonitor/img/Windmonitor2017/WERD 2017 180523 Web 96ppi.pdf

Fukushima Offshore Wind Consortium. "Fukushima Floating Offshore Wind Farm Demonstration Project.” http://www.fukushima-forward.jp/english/

German Bundestag, 'Renewable Energy Sources Act', (8 July 2016), 18/8860, http://www.gesetze-im-internet.de/bundesrecht/eeg 2014/gesamt.pdf

GOTO FOWT. Floating Offshore Wind Turbine. http://goto-fowt.go.jp/english/

Green Giraffe. 2018. Auction design and finance in offshore wind. Accessed July 2018. https://green-giraffe.eu/presentations/auction-design-and-finance-offshore-wind.

Hobohm, J., L. Krampe, F. Peter, A. Gerken, P. Heinrich, M. Richter. (2013). Cost Reduction Potentials of Offshore Wind Power in Germany. Prognos AG and the Fichtner Group. https://www.prognos.com/uploads/tx_atwpubdb/130822_Prognos_Fichtner_Studie_OffshoreWind_Kurz_EN_05.pdf

IEA-Renewable Energy Technology Deployment. 2017. Comparative Analysis of International Offshore Wind Energy Development; Rewind Offshore. http://iea-retd.org/wp-

content/uploads/2017/03/IEA-RETD-REWind-Offshore-report.pdf 
International Energy Agency. 2016. "Netherlands Offshore Wind Energy Act (Wet Wind op Zee)." https://www.iea.org/policiesandmeasures/pams/netherlands/name-158557-en.php.

KPMG International. 2014. Taxation of Cross-Border Mergers and Acquisitions: Belgium. https:/home.kpmg.com/content/dam/kpmg/pdf/2014/05/belgium-2014.pdf.

Loyens \& Loeff. 2015. North Sea offshore wind Developments in the Netherlands. http://loyensloeffwebsite.blob.core.windows.net/media/3273/briefing-april-2015.pdf.

Loyens \& Loeff. 2016. "Loyens \& Loeff congratulates Rentel on achieving financial close for its offshore wind farm." https://www.loyensloeff.com/nl-nl/news-events/news/loyens-loeffcongratulates-rentel-on-achieving-financial-close-for-its-offshore-wind-farm.

Ministry of Economy, Trade and Industry. 2015. Long-term Energy Supply and Demand Outlook. http://www.meti.go.jp/english/press/2015/pdf/0716_01a.pdf.

Mone, C., M. Hand, M. Bolinger, J. Rand, D. Heimiller, J. Ho. 2017. 2015 Cost of Wind Energy Review. NREL/TP-6A20-66861. National Renewable Energy Laboratory, Golden, CO (US). https://www.nrel.gov/docs/fy17osti/66861.pdf.

Musial, W., P. Beiter, P. Schwabe, T. Tian, T. Stehly, P. Spitsen. 2017. 2016 Offshore Wind Technologies Market Report. DOE/GO-102017-5031. U.S. Department of Energy, Washington, D.C. https://www.energy.gov/sites/prod/files/2017/08/f35/2016\%20Offshore $\% 20$ Wind $\% 20$ Technologies \%20Market $\% 20$ Report.pdf.

NEDO. 2013a. "Full-scale demonstration operation start!" Choshi offshore site report in Chiba Prefecture http://www.nedo.go.jp/fuusha/report_choshi.html.

NEDO. 2013b. "Looking back on Kitakyushu maritime offshore windmill/installation work." Fukuoka Prefecture Kitayushu-shi off-shore report.

http://www.nedo.go.jp/fuusha/report_kitakyushu.html.

Netherlands Enterprise Agency. Undated. Driving down offshore wind costs the Dutch way. https://english.rvo.nl/sites/default/files/2017/05/Factsheet\%20Driving\%20down $\% 20$ offshore $\% 2$ 0wind $\% 20$ costs $\% 20$ the $\% 20$ Dutch $\% 20$ way.pdf

Netherlands Enterprise Agency (RVO.nl). 2016. https://www.lmwindpower.com/en/stories-andpress/stories/news-from-lm-places/dutch-wind-days-2016.

Office of Gas and Electricity Markets. 2018. "Renewables Obligation (RO) buy-out price and mutualization ceilings for 2018-19 RO year." https://www.ofgem.gov.uk/publications-andupdates/renewables-obligation-ro-buy-out-price-and-mutualisation-ceilings-2018-19-ro-year

offshoreWIND.biz. 2016. "EC Approves Support Scheme for Rentel and Norther OWFs." December 9, 2016. https://www.offshorewind.biz/2016/12/09/ec-approves-support-scheme-forrentel-and-norther-owfs/.

offshoreWIND.biz. 2017. "Belgium Agrees on EUR 79/MWh for Three Offshore Wind Farms." October 27, 2017. https://www.offshorewind.biz/2017/10/27/belgium-agrees-on-eur-79mwh-forthree-offshore-wind-farms/. 
Offshore Wind Programme Board. 2016. Cost Reduction Monitoring Framework 2016. www.crmfreport.com.

reNEWS. 2017. "Elia to build $€ 400 \mathrm{~m}$ grid hub.” April 14, 2017. http://renews.biz/106696/elia-tobuild-400m-grid-hub/.

renewableUK. 2017. Offshore Wind Industry Investment in the UK; 2017 Report on Offshore Wind UK Content.

https://c.ymcdn.com/sites/www.renewableuk.com/resource/resmgr/publications/Offshore Wind Investment_V4.pdf.

Serrano Gonzalez, J. \& Lacal Arantegui, R. 2015. The regulatory framework for wind energy in EU Member States. https://ec.europa.eu/jrc/en/publication/eur-scientific-and-technical-researchreports/regulatory-framework-wind-energy-eu-member-states-part-1-study-social-and-economicvalue

Smart et al. 2016. IEA Wind Task 26 Offshore Wind Farm Baseline Documentation.

Tax Cuts and Jobs Act, H.R. 1. 2017. H.R.1 - An Act to provide for reconciliation pursuant to titles II and Vof the concurrent resolution on the budget for fiscal year 2018.

https://www.congress.gov/bill/115th-congress/house-bill/1. 


\section{Contact}

\section{ORE Catapult}

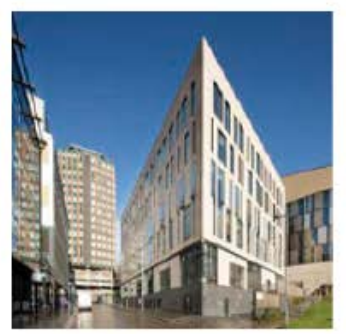

Inovo

121 George Street

Glasgow

G1 IRD, UK

T: +44 (७) 333 0041400

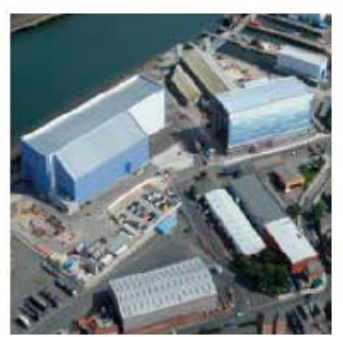

National Renewable Energy Centre

Albert Street, Blyth

Northumberland

NE24 1LZ, UK

T: +44 (Ө)1670 359555

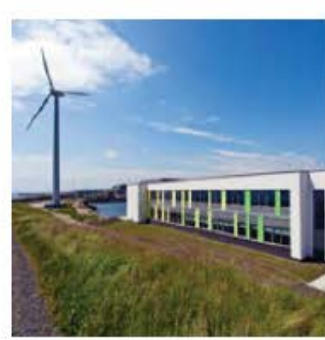

Fife Renewables Innovation Centre

Ajax Way

Leven

KY8 3RS

T: +44 (0)1670 357649

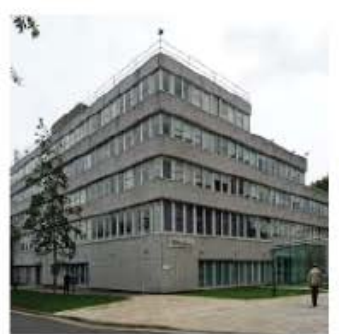

O\&M Centre of Excellence

Room 241, 2nd Floor Wilberforce Building University of Hull HU6 7RX

ore.catapult.org.uk

Tweet us: @ORECatapult // @CatapultBlyth info@ore.catapult.org.uk 